\title{
$\mathbb{1}$ Nordregio
}

Globalaima: Hokala prioriteringar: Agen of 2030 på lokel nivå

Nora Sánchez Gassen, Oskar Penje och Elin Slätmo NORDREGIO RAPPORT 2019:5
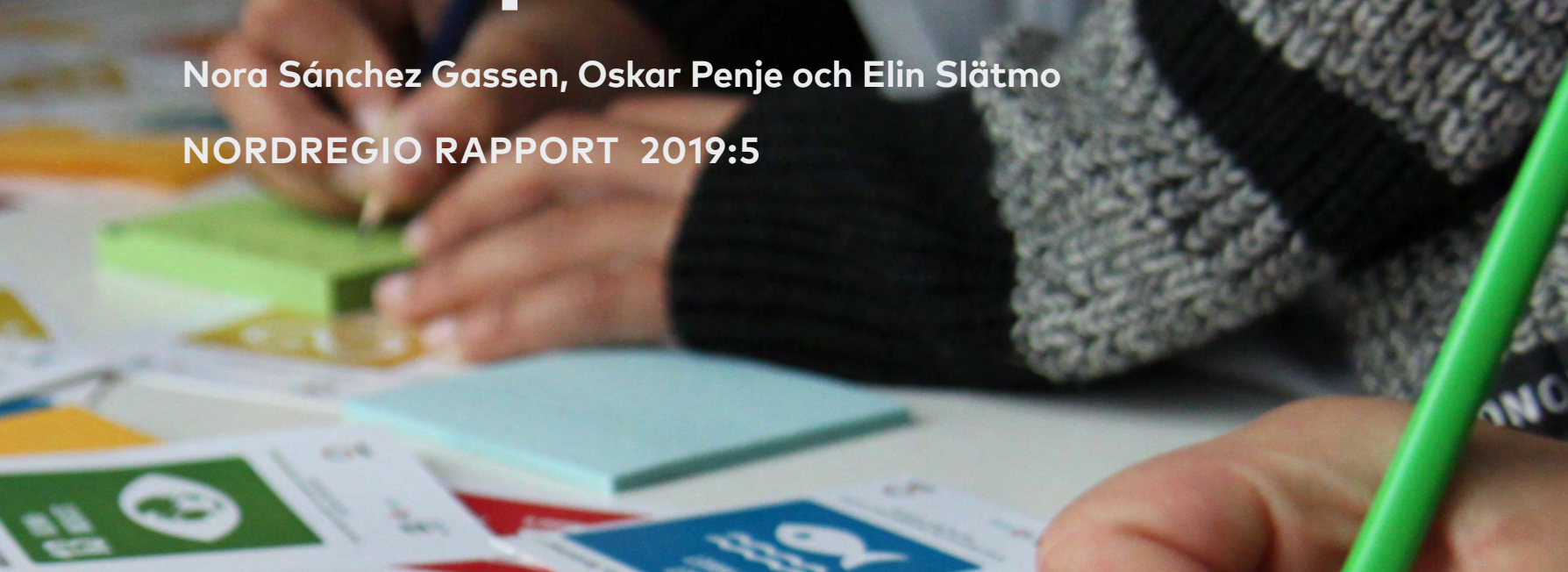

T

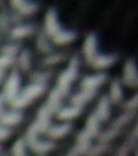





\section{Globala mål för lokala prioriteringar: Agenda 2030 på lokal nivå}

Nora Sánchez Gassen, Oskar Penje och Elin Slätmo NORDREGIO RAPPORT 2019:5 
Nordregio rapport 2019:5

ISBN 978-91-87295-70-6

ISSN 1403-2503

DOI: doi.org/10.30689/R2019:5.1403-2503

(c) Nordregio 2019

Nordregio

Box 1658

SE-111 86 Stockholm, Sverige

nordregio@nordregio.org

wWw.nordregio.org

www.norden.org

Analys och text: Nora Sánchez Gassen, Oskar Penje och Elin Slätmo Omslagsbild: House of Science, Sønderborg Municipality, Denmark Repro och tryck: Allduplo Offsettryck AB

\section{Nordregio}

är ett ledande nordiskt och europeiskt forskningsinstitut för regional utveckling och samhällsplanering, inrättat av Nordiska ministerrådet 1997. Vi bedriver lösningsorienterad och tillämpad forskning, och analyserar aktuella frågor både ur ett forskningsperspektiv och från myndigheters och praktikers synvinkel. Nordregios verksamhet sker på såväl internationell, regional som lokal nivå och forskningen omfattar ett brett geografiskt område med betoning på Norden och Östersjöregionerna, Europa och Arktis.

\section{Det nordiska samarbetet}

Det nordiska samarbetet är en av världens mest omfattande regionala samarbetsformer. Samarbetet omfattar Danmark, Finland, Island, Norge och Sverige samt Färöarna, Grönland och Åland. Det nordiska samarbetet är både politiskt, ekonomiskt och kulturellt förankrat, och är en viktig medspelare i det europeiska och internationella samarbetet. Den nordiska gemenskapen arbetar för ett förstärkt Norden i ett starkt Europa. Det nordiska samarbetet syftar till att förstärka nordiska och regionala intressen och värderingar i en global värld. Gemensamma värderingar mellan länderna bidrar till att förstärka Nordens position som en av världens mest innovativa och konkurrenskraftiga regioner.

\section{Nordiska ministerrådet}

är de nordiska regeringarnas officiella samarbetsorgan. Nordiska ministerrådet genomför det nordiska samarbetet. Statsministrarna har det överordnade ansvaret. Den praktiska verksamheten koordineras av de nordiska samarbetsministrar, Nordiska samarbetskommittén och fackministerråden. Bildades 1971.

\section{Nordiska rådet}

är det officiella nordiska samarbetets parlamentariska organ. Rådet har 87 valda ledamöter från de nordiska ländernas parlament. Nordiska rådet tar policyinitiativ och följer upp det nordiska samarbetet. Bildades 1952. 


\section{Innehåll}

Sammanfattning.

Förord

Inledning 8

Metoder och angreppssätt ………………………………………………………………………..... 9

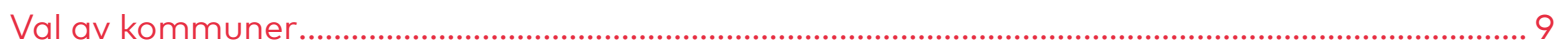

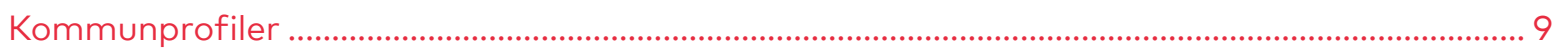

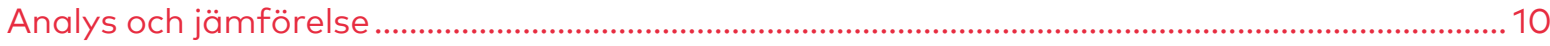

Nationellt genomförande av Agenda 2030 .........................................................................11

Nordiska föregångare i arbetet med Agenda $2030 \ldots \ldots \ldots \ldots \ldots \ldots \ldots \ldots \ldots \ldots \ldots \ldots \ldots \ldots \ldots \ldots \ldots \ldots \ldots . . . .13$

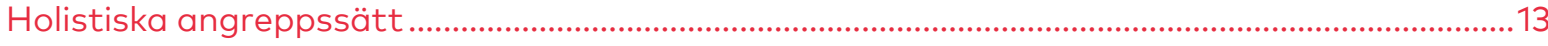

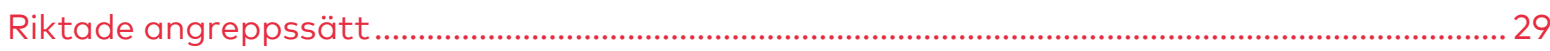

Analys: Framgångsfaktorer, utmaningar och nästa steg $i$ genomförandet av Agenda 2030 på lokal nivå ............................................................ 43

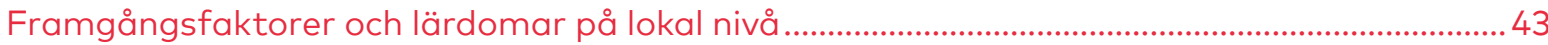

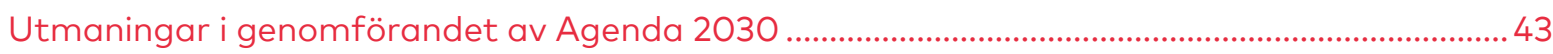

Nästa steg för genomförandet av Agenda 2030 på lokal nivå .........................................................45

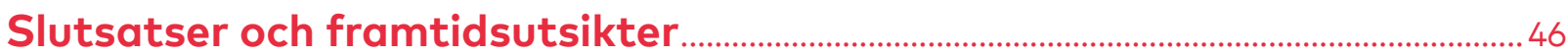

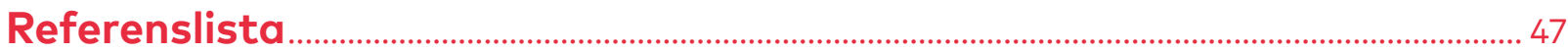

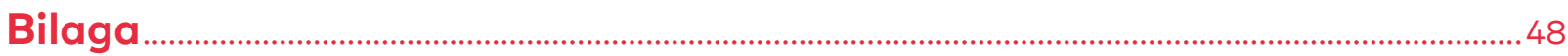

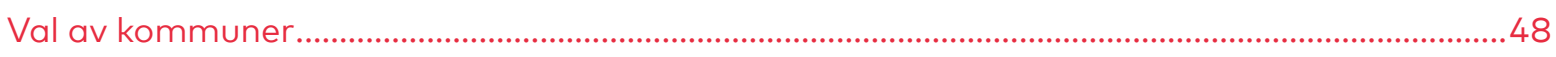

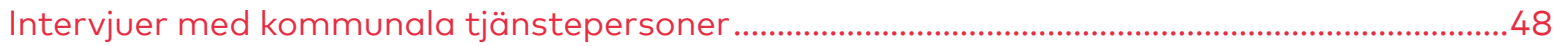

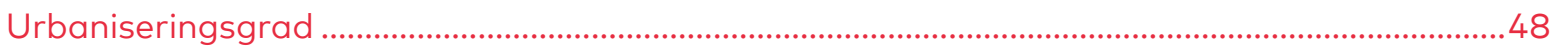

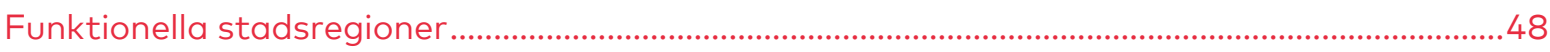

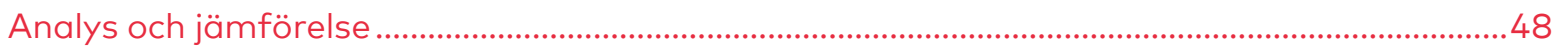

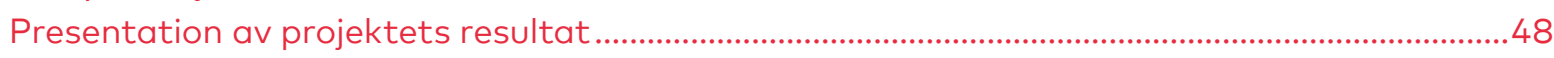




\section{Sammanfattning}

Den 25 september 2015 antog FN:s generalförsamling Agenda 2030 för hållbar utveckling och 17 Globala hållberhetsmål. Kommunerna har en nyckelroll i genomförandet av agendan och målen, eftersom de står närmast invånarna, de lokala företagen och civilsamhällets organisationer. Denna rapport identifierar 27 nordiska kommuner som är föregångare i arbetet med Agenda 2030 och beskriver deras prioriteringar och verksamheter. Den tar också upp utmaningar och framgångsfaktorer i arbetet med hållbarhetsmålen. Rapportens syfte är att ge lokala myndigheter idéer för hur de kan genomföra Agenda 2030 samt informera experter och politiska beslutsfattare på nationell och regional nivå om hur de kan stödja kommunernas arbete.

De 27 föregångskommunerna använder hållbarhetsmålen för att inspirera och vägleda nya miljöprinciper och livskvalitetsprogram, utveckling av nya förorter, framtagning av lokala strategier, sammanslagning av kommuner och många andra insatser. De har olika angreppssätt, prioriteringar och planer för att engagera lokala invånare, företag, ideella organisationer och andra partner i arbetet med hållbarhetsmålen. Trots dessa olikheter har föregångarna gemensamma förväntningar på de nationella och nordiska myndigheterna: De rekommenderar en tydligare kommunikation av nationella prioriteringar och aktiviteter inom Agenda 2030, vägledning för arbete med de 17 hållbarhetsmålen och hjälp med att följa upp framstegen. Stöd inom dessa områden skulle underlätta de lokala myndigheternas insatser för att nå hållbarhetsmålen.
Idéer från föregångskommunerna för hur Agenda 2030 kan genomföras i en lokal kontext:

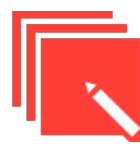
Integrera hållbarhetsmålen i centrala styrdokument, planer och processer

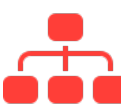

Involvera alla avdelningar hos den lokala myndigheten

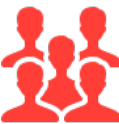

Engagera lokalbefolkningen

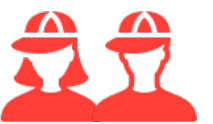

Uppmuntra unga att delta

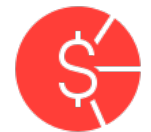

Stöd hållbara företag och organisationer

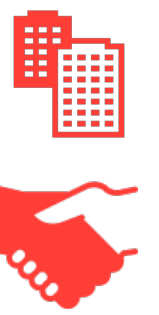

Använd hållbarhetsmålen i stadsplanering och hållbart bostadsbyggande

Ingå starka partnerskap

Fler idéer från de 27 föregångskommunerna beskrivs på sidan 43 . 


\section{Förord}

I september 2017 antog Nordiska ministerrådet programmet Generation 2030 för att stödja de nordiska länderna i genomförandet av Agenda 2030 i Norden. Programmet bygger på en stark tradition av nordiskt samarbete inom hållbar utveckling; den första nordiska strategin för hållbar utveckling antogs 2001. För perioden 2017-2020 betonar Generation 2030 särskilt hållbar konsumtion och produktion (hållbarhetsmål 12) och engagemang av unga i Norden. En annan ambition är att involvera den privata sektorn, civilsamhället, forskningsnätverk och lokala myndigheter som anses ha nyckelroller för att säkerställa att agendan verkligen lyckas.

Denna rapport presenterar en analys av hur Agenda 2030 implementeras på lokal nivå i Norden. I december 2017 gav Nordiska ministerrådet Nordregio i uppdrag att genomföra studien som en del av programmet Generation 2030. Centrala forskningsmål var att identifiera vilka nordiska kommuner som redan arbetar med de 17 målen för hållbar utveckling och att dokumentera dessa kommuners insatser och erfarenheter.

Följande forskare vid Nordregio var involverade i projektet: Nora Sánchez Gassen (projektledare), Oskar Penje och Elin Slätmo. Projektteamet vill tacka alla intervjuade i föregångskommunerna för deras tid och värdefulla information om kommunens arbete. Likaså tackar vi de många anställda vid nordiska och europeiska organisationer och intressegrupper samt Nordregios partners och intressenter som rekommenderade kommuner för detta projekt. Slutligen vill vi framföra vårt tack till dem som aktivt deltog i seminariet "Agenda 2030 at the local level" i maj 2018.
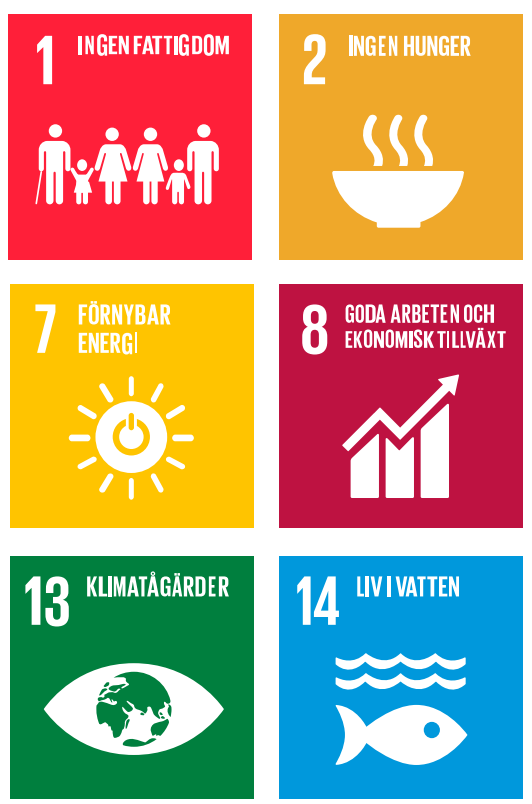
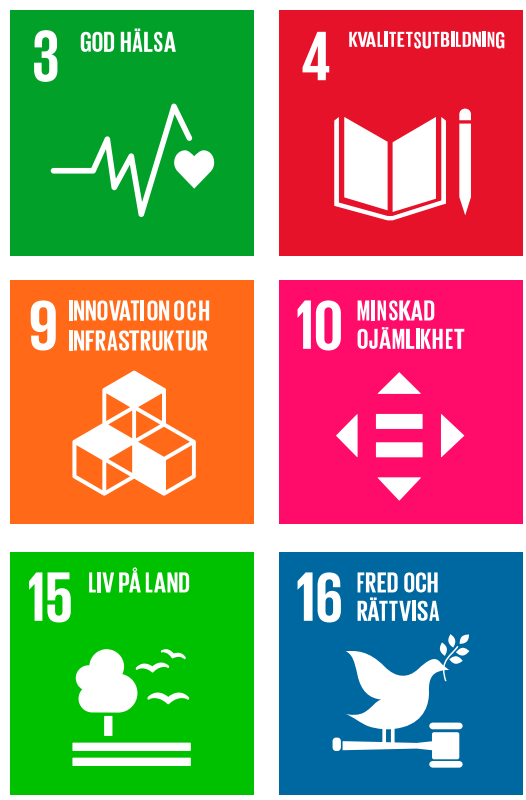
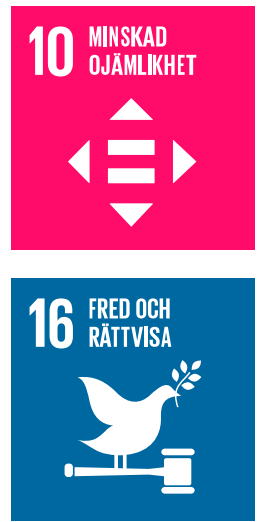
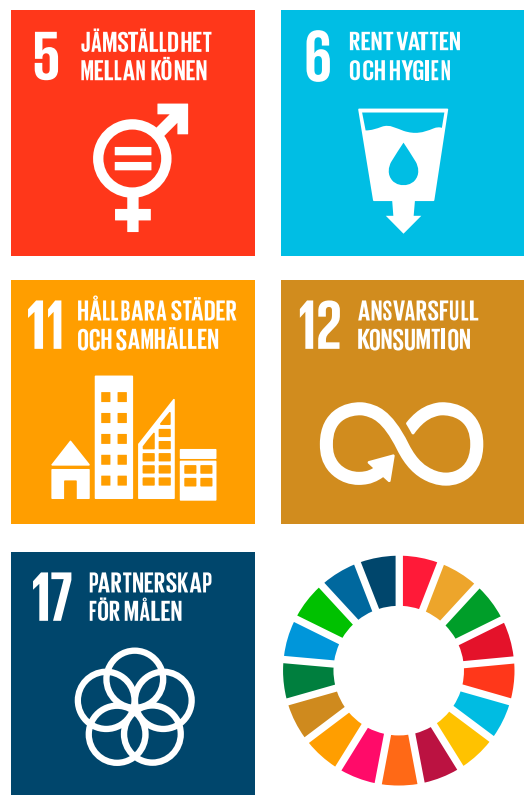

De 17 globala målen för hållbar utveckling. 


\section{Inledning}

Den 25 september 2015 antog FN:s generalförsamling Agenda 2030 för hållbar utveckling och de 17 hållbarhetsmålen för att främja social, miljömässig och ekonomisk hållbarhet. Sedan dess har regeringar, företag, organisationer, medborgare och andra aktörer inlett åtgärder för att avskaffa fattigdom, främja ekonomisk tillväxt, minska ojämlikheter, och samtidigt skydda miljön, bekämpa klimatförändringarna och arbeta för fred och rättvisa.

Genomförandet av Agenda 2030 leds av länderna. FN:s medlemsstater uppmuntras att inrätta nationella planer för att uppnå de 17 hållbarhetsmålen och många länder har publicerat frivilliga rapporter (Voluntary National Reviews, VNR) över vad de har uppnått, pågående aktiviteter och framtida mål. Det är dock de lokala myndigheterna i kommunerna som har nyckelrollen när det gäller att genomföra Agenda 2030. De står närmast invånarna, lokala företag och organisationer. Kommunerna är även ansvariga för en stor del av den sociala och fysiska infrastrukturen som påverkar befolkningens levnadsförhållanden och möjligheter. Trots detta finns det inte mycket information tillgänglig om planerna, aktiviteterna och erfarenheterna hos lokala myndigheter som arbetar med Agenda 2030. Denna rapport, Globala mål för lokala prioriteringar, försöker avhjälpa denna brist genom att ge en översikt över hur kommuner i Norden genomför hållbarhetsmålen.

De nordiska länderna toppar ofta globala rankinglistor över insatser för hållbarhetsmålen (Sachs et al. 2018). Oaktat detta har många nordiska kommuner bara precis börjat att uttryckligen koppla ihop sina hållbarhetsåtgärder med de globala hållbarhetsmålen. Denna rapport identifierar några kommuner som är föregångare i detta. Den beskriver deras huvudsakliga aktiviteter och program, och framhåller några lärdomar som an- dra kan få av deras erfarenheter av arbetet med hållbarhetsmålen. Rapporten publiceras på uppdrag av Nordiska ministerrådet och utgör en del av programmet Generation 2030 (Nordiska ministerrådet 2017). Programmet antogs i september 2017 för att underlätta samarbete om utmaningar som de nordiska länderna gemensamt möter i implementeringen av Agenda 2030 och hållbarhetsmålen.

Rapporten har följande struktur: Den första delen presenterar metoderna som användes i projektet och ger en kort beskrivning av nationella angreppssätt i genomförandet av Agenda 2030. En karta visar sedan de 27 nordiska kommunerna som intervjuades och identifierades som föregångare i arbetet med Agenda 2030. Rapportens huvuddel utgörs av korta profiltexter som beskriver hur respektive kommun arbetar med hållbarhetsmålen. Den delen avslutas med en sammanfattning av centrala idéer för hur hållbarhetsmålen kan användas $\mathrm{i}$ ett kommunalt sammanhang. I rapportens avslutande del diskuteras utmaningar och framgångsfaktorer som föregångarna hittills har mött, och därtill definieras policyrekommendationer utgående från deras förslag. Dessa rekommendationer är avsedda som förslag på hur experter och politiska beslutsfattare på nationell och regional nivå kan stötta lokala myndigheters arbete.

Det finns många sätt på vilka kommuner kan förbättra sin hållbarhet och bidra till Agenda 2030. Vi hoppas att denna rapport ska ge lokala myndigheter i och utanför Norden idéer och inspiration till hur de kan sätta igång med arbetet, utnyttja sina egna starka sidor och bidra till de globala målen genom att fokusera på lokala prioriteringar.

Stockholm, juli 2018

Nora Sánchez Gassen, Oskar Penje och Elin Slätmo 


\section{Metoder och angreppssätt}

I december 2017 gav Nordiska ministerrådet Nordregio i uppdrag att analysera implementeringen av Agenda 2030 på lokal nivå. Analysen har bestått av två delar:

Identifiering av föregångare:

Vilka nordiska kommuner arbetar med Agenda 2030 och hållbarhetsmålen?

- Beskrivning av deras arbete:

Vilka är deras uppsatta mål, vilka aktiviteter genomför de och vilka är deras erfarenheter av arbetet med hållbarhetsmålen?

\section{Val av kommuner}

För att identifiera föregångare kontaktade författarna nordiska och europeiska organisationer och intressegrupper, Nordregios partners och intressenter för att få förslag på kommuner som redan arbetar med Agenda 2030. Utifrån dessa rekommendationer kontaktades och intervjuades lokala myndigheter i Norden och de ombads också alla att rekommendera andra lokala myndigheter som arbetar med Agenda 2030. Alla kommuner som ingår i rapporten identifierades genom denna snöbollsmetod för urval.

Två kriterier användes för det slutliga valet av föregångskommuner. För det första sammankopplar alla lokala myndigheter som ingår i rapporten sitt arbete med Agenda 2030 och hållbarhetsmålen. För det andra har de redan gått vidare från planeringsstadiet och är i gång med att fatta beslut om projekt, principer och program länkade till hållbarhetsmålen eller har till och med börjat genomföra dem.

\section{Val av exempelfall: Kommuner identifierades som föregångare om de \\ - rekommenderades under urvalet med snöbollsmetoden, \\ - aktivt sammankopplar sitt arbete med Agenda 2030 och hållbarhetsmålen, \\ - har gått vidare från planeringsstadiet, och \\ - svarade på kontaktförfrågan och samtyckte till att vara med i rapporten.}

\section{Kommunprofiler}

Informationen från intervjuerna sammanfattas i rapportens kommunprofiler. Intervjumaterialet kompletterades med kommunernas strategier, rapporter eller andra typer av dokument som de intervjuade försåg författarna med. Profilerna har grupperats i två kategorier utifrån vilket angreppssätt de lokala myndigheterna använder i sitt arbete med 2030 Agenda:

Holistiskt angreppssått: Vissa kommuner använder hållbarhetsmålen för att integrera ett hållbarhetsperspektiv på alla administrativa nivåer och i all verksamhet. Det här görs exempelvis genom att knyta centrala styrdokument som lokala planer och strategier (Hurdal, Bergen, Köpenhamn, Kópavogur, Gladsaxe), lokala mål (Kristiansund, Örebro, Uppsala) eller program för hållbarhet och livskvalitet (Åtvidaberg, Växjö, Helsingborg, Odense) till Agenda 2030, anpassa ledningssystem (Kemi, Malmö) eller använda hållbarhetsmålen som vägledning vid kommunsammanslagning (Asker). Vi beskriver dessa kommuners arbete med hållbarhetsmålen som ett "holistiskt angreppssätt".

Riktat angreppssått: Andra kommuner arbetar med Agenda 2030 och hållbarhetsmålen inom specifika projekt eller policyområden eller använder dem för specifika ändamål. Exempelvis har de lokala myndigheterna i Mosfellsbær, Mariehamn, Birkala och Tórshavn kopplat sin miljöpolitik eller sina miljömål till Agenda 2030, Sermersooq har använt hållbarhetsmålen för en plan för stadsutveckling, Arendal och Århus fokuserar på klimatfrågor och utsläppsminskning, medan Sønderborg har startat ett ambitiöst projekt för att undervisa invånarna om Agenda 2030 och göra dem till ambassadörer för hållbarhet. Gotland planerar att förbinda en regional utvecklingsplan till hållbarhetsmålen, Umeå ställer olika aktiviteter, som kommunens program för folkhälsa, i relation till Agenda 2030 och Tammerfors hänvisar till hållbarhetsmålen i sina innovationsoch upphandlingspolicyer. Slutligen behandlar Esbo hållbarhetsmålen genom olika projekt inom stadens fyraåriga hållbarhetsprogram. Nedan har vi klassificerat dessa lokala myndigheters profiler inom gruppen "riktade angreppssätt". 
Kommunprofilerna inom respektive kategori har listats enligt invånarantal. Ikonerna i början av varje profil visar om kommunen arbetar med alla 17 hållbarhetsmål eller prioriterar vissa mål framför andra. Denna information gavs av kommunens intervjuade tjänstepersoner. Varje profil innehåller information om invånarantal som hämtats från de nationella statistiska centralbyråerna. Eurostats definitioner av urbaniseringsgrad (DEGURBA) används för att klassificera kommunerna. Om kommunen också är del av det som OECD definierar som en funktionell stadsregion (functional urban area, FUA) har den informationen lagts till i profilen (OECD, 2013). Observera att kommuner på Grönland och Färöarna inte har klassifikationer enligt DEGURBA eller FUA.

Varje profil beskriver hur och varför kommunen började arbeta med hållbarhetsmålen ("Utgångspunkt"), vad den försöker uppnå ("Mål och prioriteringar:"), vilka de huvudsakliga aktiviteterna och projekten är ("Genomförande och resultat") samt mål uppsatta för de kommande åren ("Nästa steg").

\footnotetext{
${ }^{1}$ https://ec.europa.eu/eurostat/web/degree-of-urbanisation/background
}

Varje profil avslutas med särskilt intressanta idéer, projekt eller tillämpningar som kommunen har utvecklat. Dessa idéer visas i tabell 1. De kan fungera som inspirationskälla för andra kommuner som ska påbörja arbetet med Agenda 2030.

\section{Analys och jämförelse}

Rapportens sista del sammanfattar erfarenheterna från de 27 kommunerna som har definierats som föregångare. Vilka är framgångsfaktorerna som de har identifierat i sitt arbete? Vilka utmaningar har de stött på och vilka är deras eventuella nästa steg? Denna del baseras på en analys av samtliga intervjuer med syftet att hitta gemensamma mönster och teman.

I hela rapporten använder vi följande nyckeltermer: "Kommun" syftar på en stad eller ett område med en lokal styrelse. "Lokal myndighet" syftar på de administrativa organ och organisationer som styr kommunen. Ytterligare information om identifieringen och urvalet av föregångarkommuner, intervjuerna, DEGURBA- och FUA-klassificeringarna samt analyserna finns i rapportens bilaga. 


\section{Nationellt genomförande av Agenda 2030}

De nordiska länderna följer sinsemellan olika strategier för genomförandet av Agenda 2030 och definierar en nationell ram som kan påverka hur kommunerna prioriterar, planerar och kommunicerar sitt arbete med hållbarhetsmålen.

Danmarks regering betraktar kommunerna som centrala partners för att uppnå Agenda 2030, eftersom de befinner sig närmast invånarna och företagen och ansvarar för att producera de flesta offentliga tjänsterna (Danmarks regering 2017). Detta kan vara förklaringen till det stora antalet danska kommuner som redan implementerat Agenda 2030. Antalet potentiella danska föregångskommuner som rekommenderades under projektets gång var i själva verket så stort att alla inte kunde kontaktas och intervjuas. Författarna ställde därför kommunerna i rangordning enligt hur många gånger de rekommenderades och intervjuade dem som kom högst på listan. Motivet till det här förfarandet var att kommunerna som rekommenderades oftast sannolikt var de som kommit längst i sitt arbete med hållbarhetsmålen och kunde därmed definieras som föregångare. Jämfört med de övriga nordiska länderna stöttar danska lokalpolitiker i speciellt hög grad arbetet med Agenda 2030 (Deloitte 2018). I flera kommuner hade det första initiativet till att tillämpa hållbarhetsmålen kommit från enskilda politiker eller partier. Många av de danska lokala myndigheterna som ingår i rapporten betonade även starkt betydelsen av att engagera invånarna i arbetet med Agenda 2030. De har utvecklat kreativa idéer och verktyg för att kommunicera sitt arbete.

Finlands kommission fo̊r hållbar utveckling har skapat webbplatsen "Sitoumus2050/Commitment2050" (Åtagande2050) som nationellt instrument för hållbar utveckling och Agenda 2030 (Finlands kommission för hållbar utveckling 2016). Offentliga och privata organisationer, företag och privatpersoner uppmuntras att publicera konkreta åtaganden för hållbar utveckling på webbplatsen.
Alla finska föregångskommuner använder webbplatsen för att informera allmänheten om sitt arbete med Agenda 2030. Många finska kommuner har en lång historia av att arbeta med hållbarhetsfrågor. Nätverk som exempelvis Hinku-forum, som sammanför kommuner och miljöteknikexperter för att reducera utsläpp av växthusgaser på lokal nivå, fanns före Agenda 2030. Ett flertal kommuner ingår redan i den här typen av nätverk. Det här kan vara en förklaring till varför antalet lokala myndigheter som uttryckligen sammankopplar sitt pågående miljöarbete till de globala hållbarhetsmålen är mindre i Finland än i vissa andra nordiska länder.

På Island har endast några få kommuner börjat arbeta med Agenda 2030. Den huvudsakliga förklaringen till denna brist på aktivitet kan stå att finna på nationell nivå. Den isländska regeringen har först nyligen publicerat en statusrapport över nationella prioriteringar i genomförandet av Agenda 2030 (Islands regering 2018). Några lokala tjänstepersoner som intervjuades för detta projekt påpekade att den tidigare avsaknaden av vägledning gjorde det svårt att genomföra Agenda 2030 på lokal nivå. Det är sannolikt att antalet föregångare på Island kommer att öka i och med att regeringen nu har publicerat nationella prioriteringar och information om hur arbetet med hållbarhetsmålen kan gå till.

Norge var ett av de första länderna som publicerade en frivillig rapport (VNR) över sitt genomförande av Agenda 2030 och betraktar hållbarhetsmålen som ett viktigt verktyg för att öka nationella och internationella hållbarhetsåtgärder (Norges regering 2016). Flera kommuner i Norge har förbundit sig till arbete med Agenda 2030 och några har formulerat ambitiösa planer. Exempelvis kommer Asker, Hurum och Røyken att sammanslås 2020 och har beslutat att basera den nya kommunens centrala styrdokument på de globala hållbarhetsmålen. Många andra kommuner har starka traditioner av arbete med hållbarhetsärenden, men har inte (ännu) kopplat dessa aktiviteter till de globala målen (Deloitte 2018). 
Sverige kommer regelbundet upp som ett ledande land i hållbarhetsmätningar (Sachs et al. 2018) och den svenska regeringen vill också att landet ska vara ledande i genomförandet av hållbarhetsmålen. Det publicerades nyligen en handlingsplan för genomförandet av Agenda 2030 (Regeringskansliet 2018), och en delegation med offentliga och privata aktörer är tillsatt för arbetet nationellt. Kommunerna identifieras som nyckelaktörer för att nå hållbarhetsmålen, eftersom de ansvarar för många väsentliga tjänster som påverkar människors levnadsförhållanden och företags verksamhetsmiljöer. Många kommuner $\mathrm{i}$ Sverige har antagit uppdraget och implementerar redan Agenda 2030. Liksom i Danmark, var anta- let potentiella svenska exempelfall som rekommenderades så stort att alla inte kunde intervjuas. Ett förhållandevis stort antal av de svenska kommunerna som ingår $\mathrm{i}$ rapporten arbetar på ett holistiskt sätt med hållbarhetsmålen. Exempelvis anpassar de ledningssystem och lokala mål till Agenda 2030 eller genomför agendan genom sin stadsplanering.

I de tre självstyrande områdena Fåröarna, Grönland och Åland har lokalt genomförande av Agenda 2030 också inletts. En kommun från vart och ett av dessa områden ingår i rapporten. Alla tre föregångare har startat arbetet med Agenda 2030 inom specifika sektorer, såsom miljö och stadsplanering. 


\section{Nordiska föregångare i arbetet med Agenda 2030}

Totalt 27 kommuner identifierades som föregångare i arbetet med Agenda 2030 i Norden. Figur 1 visar att gruppen av föregångare omfattar såväl stora städer som små samhällen från alla nordiska länder och regioner.

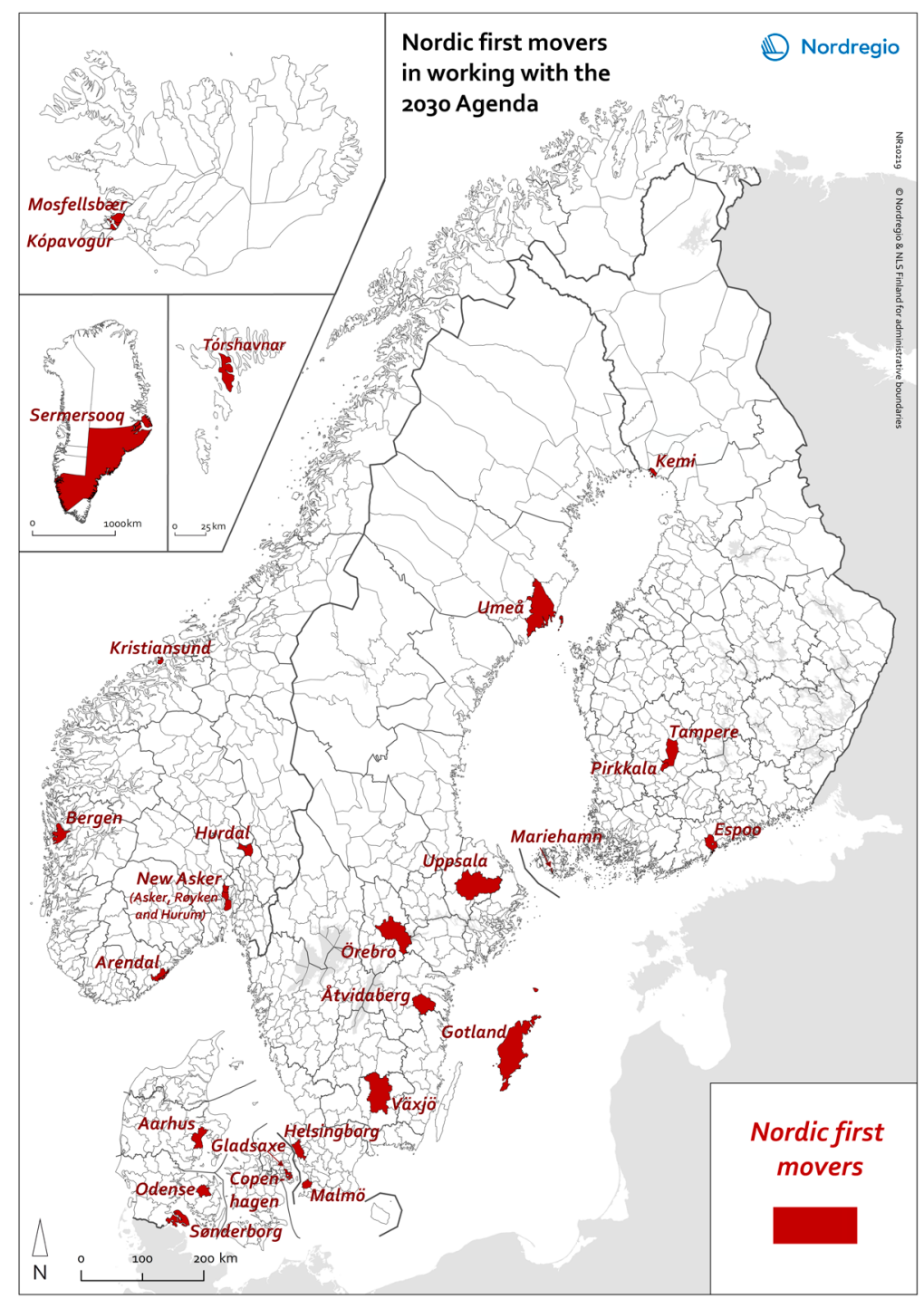

Figur 1: Nordiska föregångare i arbetet med Agenda 2030.

\section{Holistiska angreppssått}

Följande kommuner har konstaterats använda ett holistiskt angreppssätt i sitt arbete med Agenda 2030: Köpenhamn (DK), Malmö (SE), Bergen (NO), Uppsala (SE), Odense (DK), Örebro (SE),
Helsingborg (SE), Asker (NO), Växjö (SE), Gladsaxe (DK), Kópavogur (IS), Kristiansund (NO), Kemi (FI), Åtvidaberg (SE) och Hurdal (NO). Deras arbete beskrivs i profilerna i denna del. 


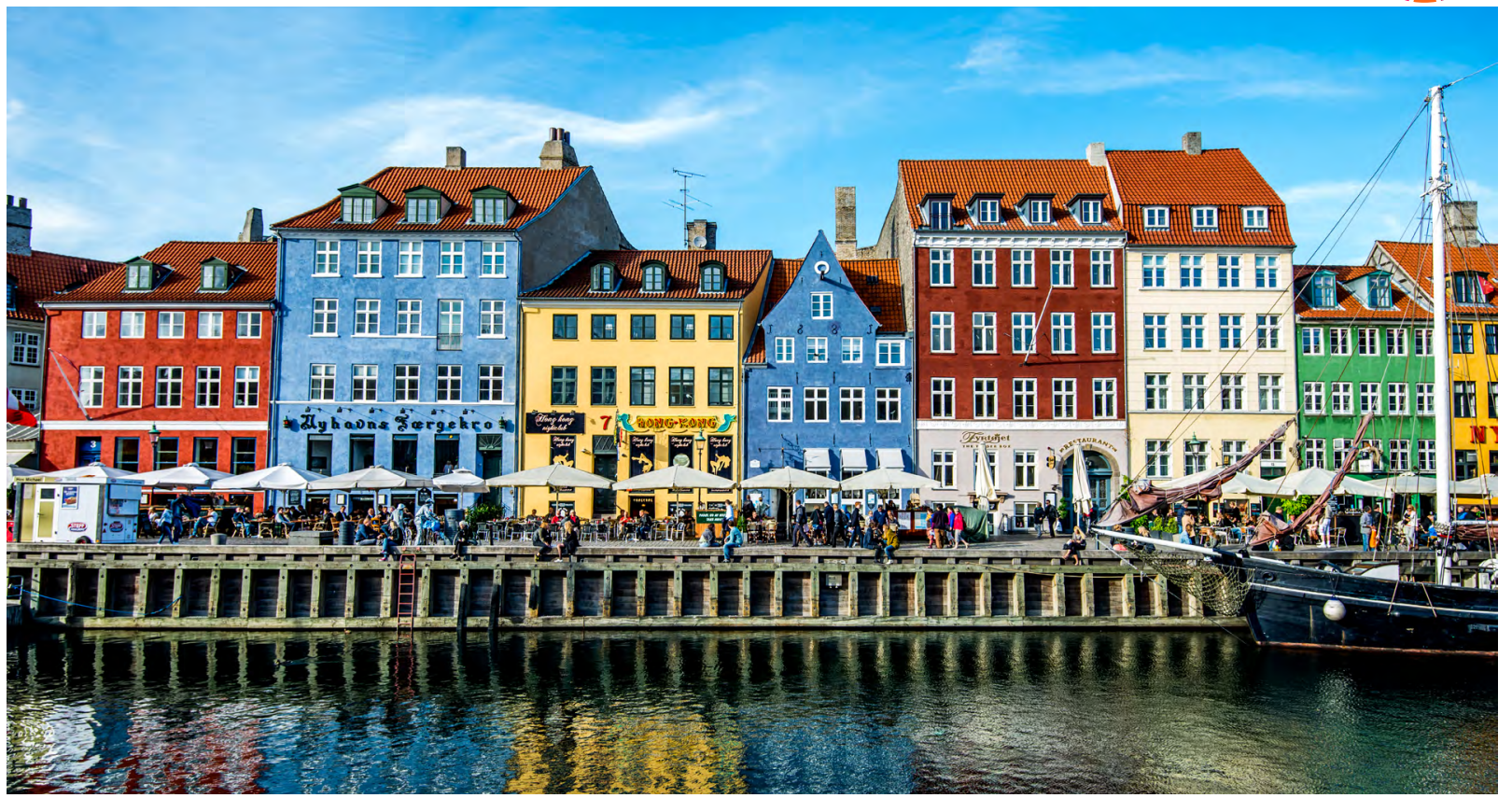

Källa: Jacob Schjørring \& Simon Lau, Copenhagen Media Center

Invånarantal: 613,288 (2018)

- Tätbefolkad kommun. Kärna i den funktionella stadsregionen Köpenhamn.

Utgångspunkt: | april 2017 föreslog det socialliberala partiet Radikale Venstre att en handlingsplan skulle antas för hur kommunen kan bidra till genomförandet av Agenda 2030 och hållbarhetsmålen. Övriga partier understödde idén och en tvärsektoriell arbetsgrupp etablerades för att ta fram en plan. Handlingsplanen som gruppens arbete resulterade i antogs av kommunfullmäktige den 12 oktober 2017. Köpenhamns ambition är att vara en av de mest hållbara städerna i världen och att bidra till att göra världen mer hållbar genom att sprida lokala lösningar till andra städer. Mål och prioriteringar: Köpenhamns handlingsplan beskriver hur de lokala myndigheternas pågående program och initiativ redan bidrar till Agenda 2030 och lyfter fram områden där staden kan göra ännu mer (Københavns Kommune 2018). Vidare definierar planen relevanta lokala mål som sammanhänger med hållbarhetsmålen och beskriver vilka program och initiativ som måste genomföras för att uppnå dem. Köpenhamns kommun fokuserar starkt på att säkerställa att alla invånare förstår Agenda 2030, känner till lokala aktiviteter relaterade till hållbarhetsmålen och vet hur de ska tillämpa dem i sitt dagliga liv.
Genomförande och resultat: Flera pågående kommunala aktiviteter bidrar redan till genomförandet av hållbarhetsmålen. Exempelvis har Köpenhamn avancerade planer på att göra staden kolneutral fram till 2025. Staden är också på god väg att säkerställa att $95 \%$ av alla ungdomar får eftergymnasial eller högre utbildning. Den tvärsektoriella arbetsgruppen planerar genomförandet av andra åtgärder som definieras $i$ handlingsplanen. Gruppen försöker även engagera företag, ideella organisationer och andra partners för att åstadkomma offentligt ägarskap av processen. Ett sätt för lokala invånare att delta är att gå med i Köpenhamns levande laboratorier, områden i staden där innovativa lösningar för lokala utmaningar utvecklas.

Nåsta steg: Köpenhamns kommun kommer att använda handlingsplanen för att utvärdera vilken effekt alla framtida planer och initiativ har på hållbarhetsmålen och de 49 lokala målen. Kommunen har även för avsikt att publicera en handbok för hur invånare, företag och organisationer kan arbeta med hållbarhetsmålen. Samarbete och kunskapsdelning med andra kommuner ska förstärkas genom sådana nätverk som C40 och Eurocities. Vad kan andra kommuner lära sig av Köpenhamn? Hur lokala laboratorier kan användas för att engagera lokalbefolkningen i att utveckla innovativa lösningar för hållbarhetsmålen. 


\section{Malmö (SE)}

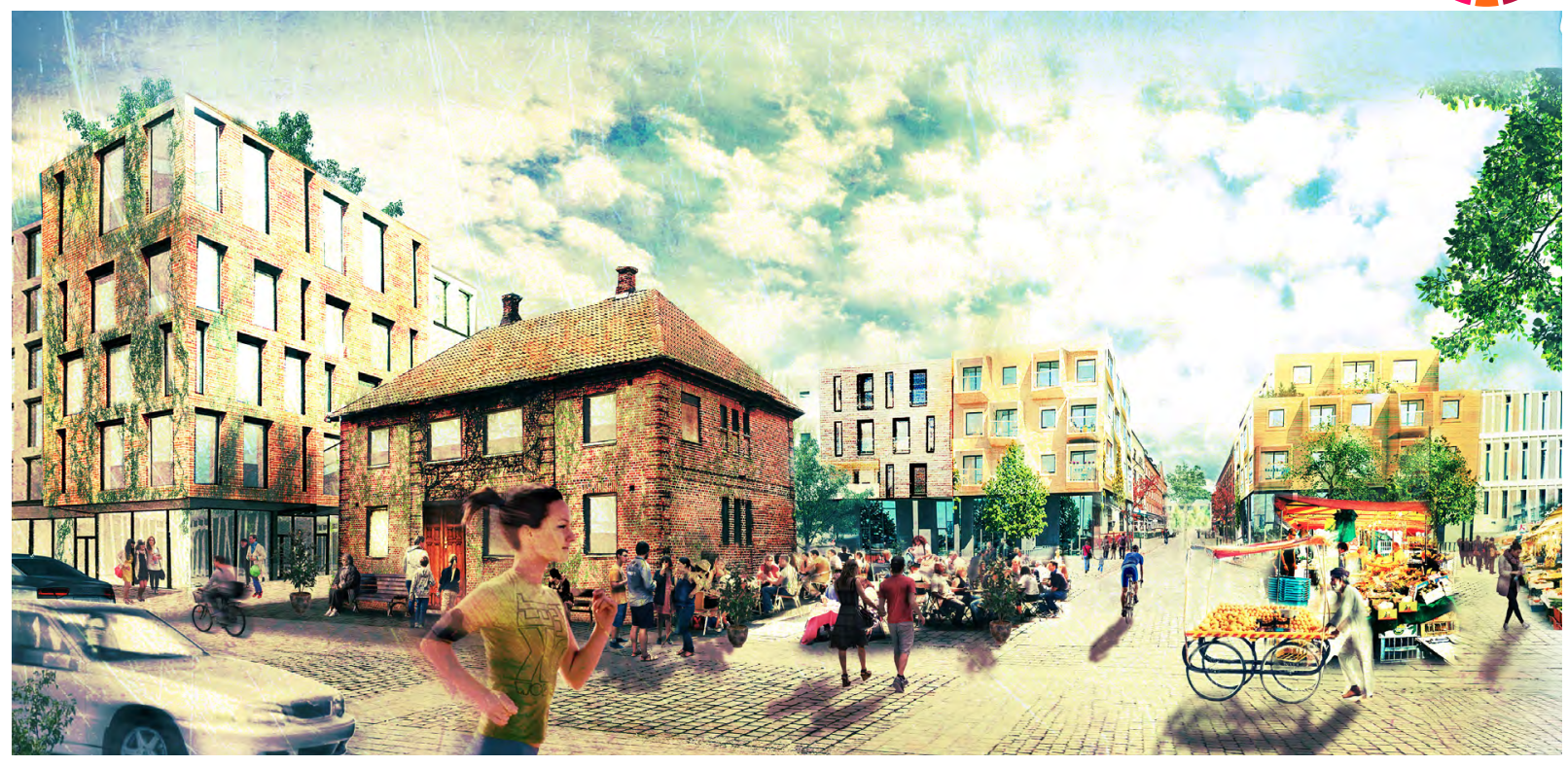

Källa: Ludvig von Hofsten, Malmö stad

- Invånarantal: 333,633 (2018)

- Medeltät kommun. Kärna i den funktionella stadsregionen Malmö.

Utgångspunkt: Malmö stad undertecknade 2015 en deklaration med syftet att ändra den lokala förvaltningens struktur för att underlätta arbetet med Agenda 2030. Den huvudsakliga drivande kraften var kommunstyrelsens ordförande som vill göra Malmö till ett hållbart samhälle. Kommunfullmäktige har arbetat med hållbarhetsfrågor sedan Agenda 21 antogs på 1990-talet, exempelvis i förhållande till stadsplanering och välfärd. Malmö var också en av de första städerna i världen som inrättade en Kommission för social hållbarhet.

Mål och prioriteringar: Kommunen genomförde en kartläggning för att se hur kommunens nio lokala mål relaterar till Agenda 2030. Kartläggningen visade att alla 17 hållbarhetsmål är relevanta för Malmö, men sju betonas i de lokala målen: mål 1: ingen fattigdom, mål 3: hälsa och välbefinnande, mål 4: god utbildning för alla, mål 5: jämställdhet, mål 10: minskad ojämlikhet, mål 11: hållbara städer och samhällen, och mål 16: fredliga och inkluderande samhällen. Under 2017 och 2018 har kommunen intensifierat sina insatser för mål 14: hav och marina resurser, och specifikt för Malmös roll som en framtida kuststad i samarbete med Local Governments for Sustainability (ICLEI) och andra nätverk.
Genomförande och resultat: I och med att Malmö undertecknade deklarationen 2015 åtog sig kommunen att anpassa sina styr-och ledningssystem till Agenda 2030 fram till år 2020. Detta arbete har framskridit väl. Anställda vid det nyligen inrättade Hållbarhetskansliet tar fram en strategiskt integrerad plan för att utöka, följa upp och förstärka arbetet. Det finns också aktiviteter som direkt anknyter till Agenda 2030, exempelvis använder museer och skolor olika laboratorier, pedagogiska center och innovationer för att engagera barn och unga i arbetet med hållbar utveckling. Kommunen har också ett nära samarbete med det lokala företagsnätverket för hållbarhet, Meet Malmö.

Nästa steg: Genomförandet av Agenda 2030 betraktas i Malmö som en lärandeprocess och de lokala myndigheterna fortsätter arbeta med att integrera hållbarhetsmålen i stadens budgetprocess. Kommunen har inrättat en gemensam beredningsenhet för ekonomi och hållbarhet som ska anpassa Malmös budget till arbetet med hållbarhetsmålen och undersöka möjligheter att finansiera hållbarhetsprojekt. Den ekonomiska integrationen betraktas som väsentlig för arbetet och säkerställer att långvariga investeringar analyseras avseende miljömässiga och sociala konsekvenser innan beslut fattas om dem.

Vad kan andra kommuner låra sig av Malmö? Hur hållbarhetsmålen kan integreras i budget- och beslutsprocesserna. 


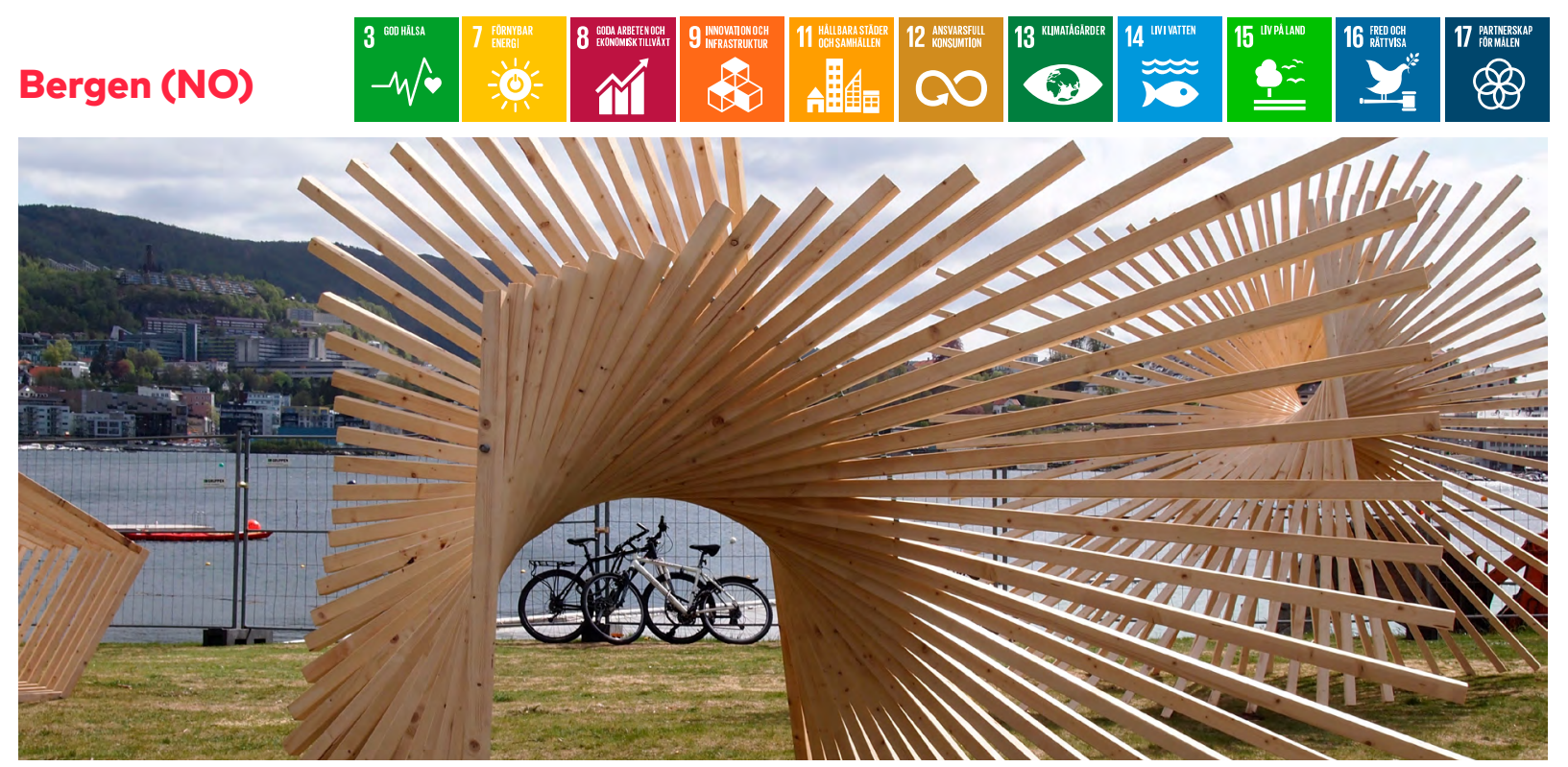

Källa: Elisabeth Sørheim, Bergens kommun

Invånarantal: 279,792 (2018)

- Medeltät kommun. Kärna i den funktionella stadsregionen Bergen.

Utgångspunkt: Integrering av Agenda 2030 i den lokala planeringen var ett naturligt steg för Bergens kommun, eftersom staden har arbetat aktivt med hållbarhetsutveckling sedan 1990-talet. Bergen införlivade FN-programmet Agenda 21 i strategiska dokument efter lanseringen 1992 och 1999 hade staden godkänt sin första klimathandlingsplan. MIK-reformen ${ }^{2}$ anses också ha varit avgörande för att skapa kunskap om hållbart miljöarbete. Kommunen har kunnat basera sitt arbete med Agenda 2030 på dessa etablerade strukturer och erfarenheter. Bergen implementerar nu Agenda 2030 genom alla lokala styrdokument och strategier.

Mål och prioriteringar: Samhällsdelen och arealdelen i Bergens kommunplan samt stadens grön- och näringsstrategi har alla tydlig anknytning till relevanta hållbarhetsmål (Bergen Kommune 2015). I näringsstrategin konstateras det exempelvis att grön och hållbar utveckling ska vara de övergripande principerna i all planering och alla åtgärder inom organisationen och kommunen (Bergen Kommune 2017). Infrastruktur, transportplanering och smart stadstillväxt är nyckelteman. Bergen är en växande stadsregion som har gått in för att vara

\footnotetext{
2 MIK "Miljøvern i kommunene" (Miljöskydd i kommunerna) var en nationell reform som genomfördes 1992-1996 med målet att bygga upp kompetens inom förvaltning av naturresurser i kommunerna.
}

den första kommunen i Norge som uppnår de nationella klimatmålen och är fossilfri fram till 2030. Ambitionen är att göra Bergen den grönaste stadsregionen i Norge. Kommunen har även ambitiösa planer för näringslivet. Näringsstrategin innehåller klara riktlinjer för vilken typ av tillväxt som prioriteras, med tydlig anknytning till de hållbarhetsmål som är relevanta för hållbar tillväxt. Bergen vill ge fördelar i den regionala affärsmiljön till företag som fokuserar på hållbara arbetsmiljöer och ansvarsfull resursanvändning. Hållbarhetsmål 11: hållbara städer och samhällen, framhålls också som viktigt för Bergen och är relevant för alla lokala myndighetsavdelningar.

Genomförande och resultat: I en stad av Bergens storlek kommer en avsevärd andel av växthusgasutsläppen från transportsektorn. Därför är det av avgörande vikt att skapa en förändring i hur hushållen fattar sina dagliga transportbeslut. Ett effektivt sätt att förverkliga detta är genom långsiktig fysisk planering av infrastruktur och bostäder, och invånarnas resvanor kartläggs regelbundet för att följa upp framstegen i detta.

Nåsta steg: Bergens kommun antog 2016 en ny handlingsplan för klimat och energi med titeln "Grønn strategi" (Bergen Kommune 2016). Kommunen främjar nu aktivt genomförandet av planen inom alla offentliga förvaltningar och uppmuntrar aktörer inom den privata sektorn samt vanliga invånare att ge arbetet sitt fulla stöd.

Vad kan andra kommuner låra sig av Bergen? Att koppla sin näringslivsstrategi till hållbarhetsmålen och därigenom stödja hållbart företagande. 


\section{Uppsala (SE)}

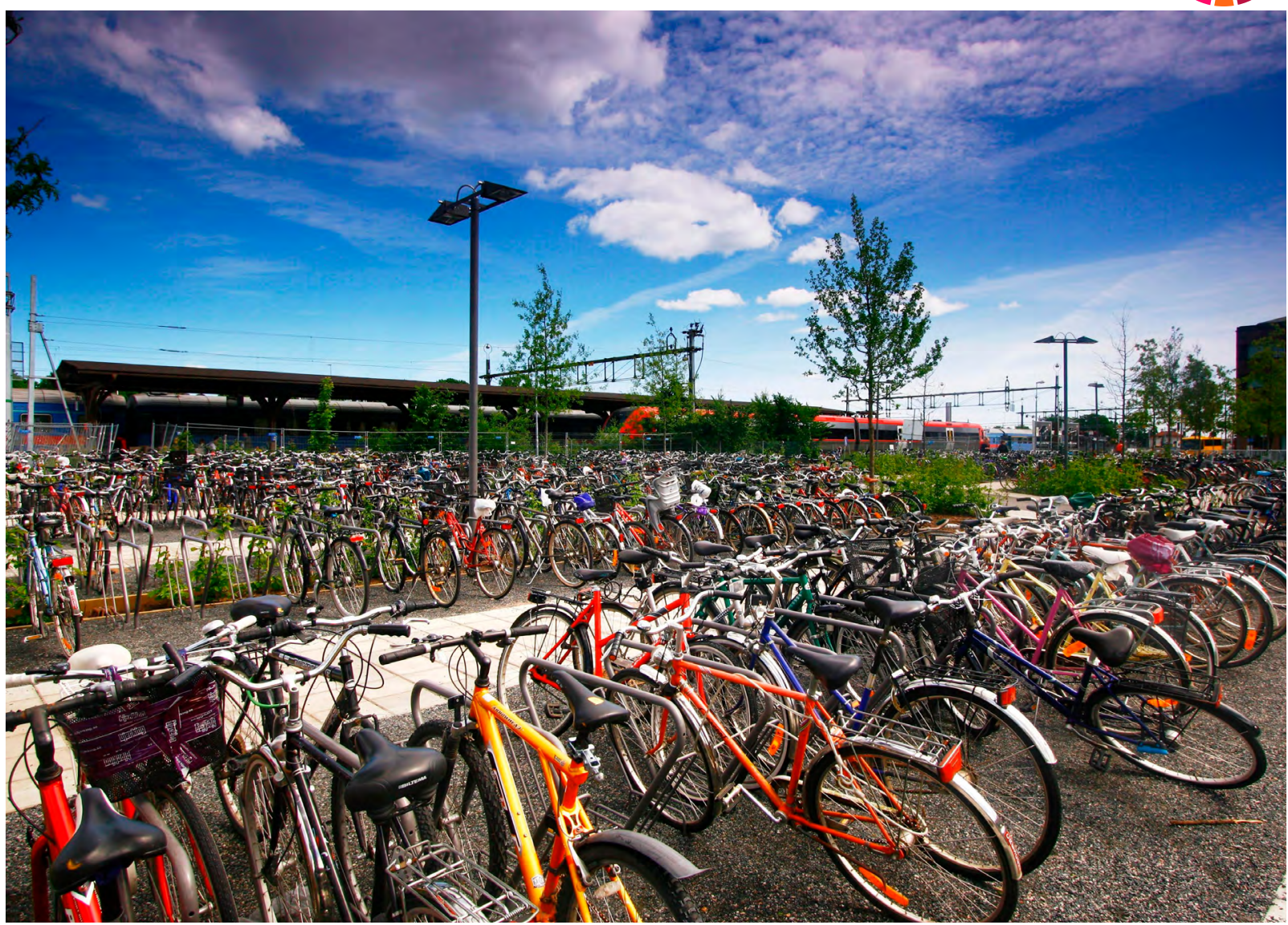

Källa: Michal Gorski, Wikimedia Commons, CC BY-SA 3.0

Invånarantal: 219,914 (2018)

- Medeltät kommun. Kärna i den funktionella stadsregionen Uppsala.

Utgångspunkt: Uppsala har haft en plan för hållbar utveckling sedan 2008. Redan innan Agenda 2030 antogs formellt av FN 2015 hade kommunpolitiker i Uppsala gett stadens tjänstepersoner i uppdrag att revidera förvaltningsstrukturen för att underlätta framtida hållbarhetsarbete. Kommunens administration omorganiserades så att personal som arbetar med hållbarhet (sociala frågor, miljöärenden, ekonomi och näringsverksamhet) placerades närmare den politiska ledningen.

Mål och prioriteringar: Tjänstepersoner och politiker höll en gemensam workshop för att utforska hur hållbarhetsmålen anknyter till specifika lokala utmaningar. Tidigare hade kommunen cirka 100 mål som styrde det dagliga arbetet. Utifrån de 17 hållbarhetsmålen togs nio lokala inriktningsmål fram och en budget gjordes upp för vart och ett av dem (Uppsala kommun 2017). Alla 17 hållbar- hetsmål ansågs vara viktiga, men inte av lika stor betydelse för alla förvaltningar. Vissa sågs som mer uppenbara för kommuner av Uppsalas typ att arbeta med. Enligt lokala tjänstepersoner är dessa mål 1: ingen fattigdom, mål 2: ingen hunger, och mål 4: god utbildning för alla. Mål 1 och mål 2 kan uppnås genom att minska ojämlikheter (mål 10).

Genomförande och resultat: Politisk enighet om de nio nya lokala målen och budgeten nåddes 2017. Sedan dess har målen styrt arbetet vid samtliga avdelningar och organisationer i kommunen. Målen används även för att följa upp hur de enskilda avdelningarna bidrar till det lokala, nationella och globala arbetet för att uppnå Agenda 2030.

Nåsta steg: Tjänstepersoner har tagit fram en "social kompass" som kombinerar statistisk och rumslig analys. Den används nu som underlag för prioritering av hållbarhetsmålen i olika stadsdelar och för att kommunicera med beslutsfattare på lokal nivå.

Vad kan andra kommuner lära sig av Uppsala? Hur rumslig analys kan användas för att besluta vilka hållbarhetsmål som ska prioriteras i olika stadsdelar. 


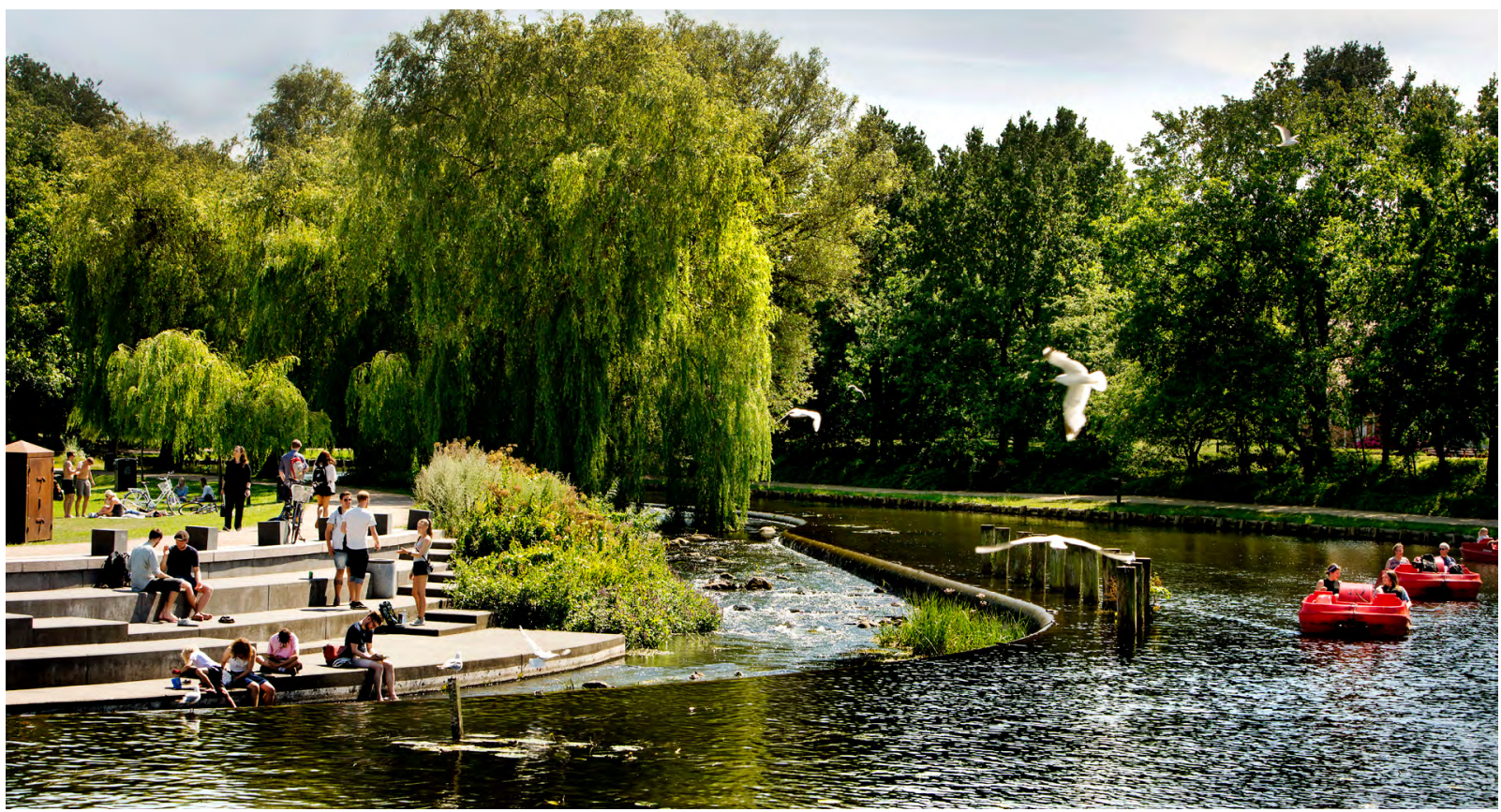

Källa: Nils Lund, Odense kommun

- Invånarantal: 202,348 (2018)

- Tätbefolkad kommun. Kärna i den funktionella stadsregionen Odense.

Utgångspunkt: Odense planerar att genomföra Agenda 2030 genom en ny policy för hållbar utveckling. Kommunen har en lång historia av arbete med hållbarhetsinitiativ och inrättade en hållbarhetsnämnd, Odense Bæredygtighedsråd, 2009 för att främja hållbara lösningar. När Agenda 2030 antogs identifierade kommunen många överlappningar mellan hållbarhetsmålen och sin egen syn på hållbarhet, så kommunstyrelsen gick in för att använda de globala målen som en ny ram för lokala insatser.

Mål och prioriteringar: Odense tillsätter ett nytt utskott för hållbar utveckling, Verdensmål Udvalget, som ska sammanföra lokalpolitiker, intressenter från företag, ideella föreningar, skolor och andra organisationer. Dess uppdrag kommer att vara att ta fram en ny policy för hållbar utveckling som anknyter till de globala hållbarhetsmålen. Den nya policyn ska fokusera på ekologiska aspekter, men även social och ekonomisk hållbarhet kommer att beaktas. Utskottet ska också komma med konkreta rekommendationer för hur hållbarhetsmålen kan användas för att integrera ett genomgående hållbarhetstänkande i allt kommunalt arbete.
Genomförande och resultat: Ett antal insatser pågår redan för att öka medvetenheten om hållbarhet och de globala målen. Exempelvis delar hållbarhetsnämnden årligen utt ett pris som erkänsla och belöning till personer, organisationer eller företag som utvecklar hållbara lösningar. Kommunen tog 2010 fram ett cirkelformat pussel som visualiserar Odenses syn på hållbarhet. Det består av bitar i tre olika färger där varje färg står för en dimension av hållbarhet: social, ekologisk och ekonomisk. Alla 30 pusselbitar beskriver ett insatsområde, som integration, biodiversitet eller utbildning. Syftet är att företag, lokala myndighetsavdelningar och andra organisationer ska få inspiration till att förbättra hållbarhetseffekterna av olika projekt, insatser och kampanjer genom att diskutera de olika pusselbitarna och de åtgärdsområden som definieras på dem.

Nästa steg: Det nya utskottet för hållbar utveckling ska presentera sitt förslag till en ny policy för hållbar utveckling under nästa år och den ska antas av kommunfullmäktige. Från den nya policyn kommer en handlingsplan och konkreta åtgärder att utvecklas.

Vad kan andra kommuner lära sig av Odense? Hur hållbara lokala företag och organisationer kan främjas genom att dela ut ett hållbarhetspris. 


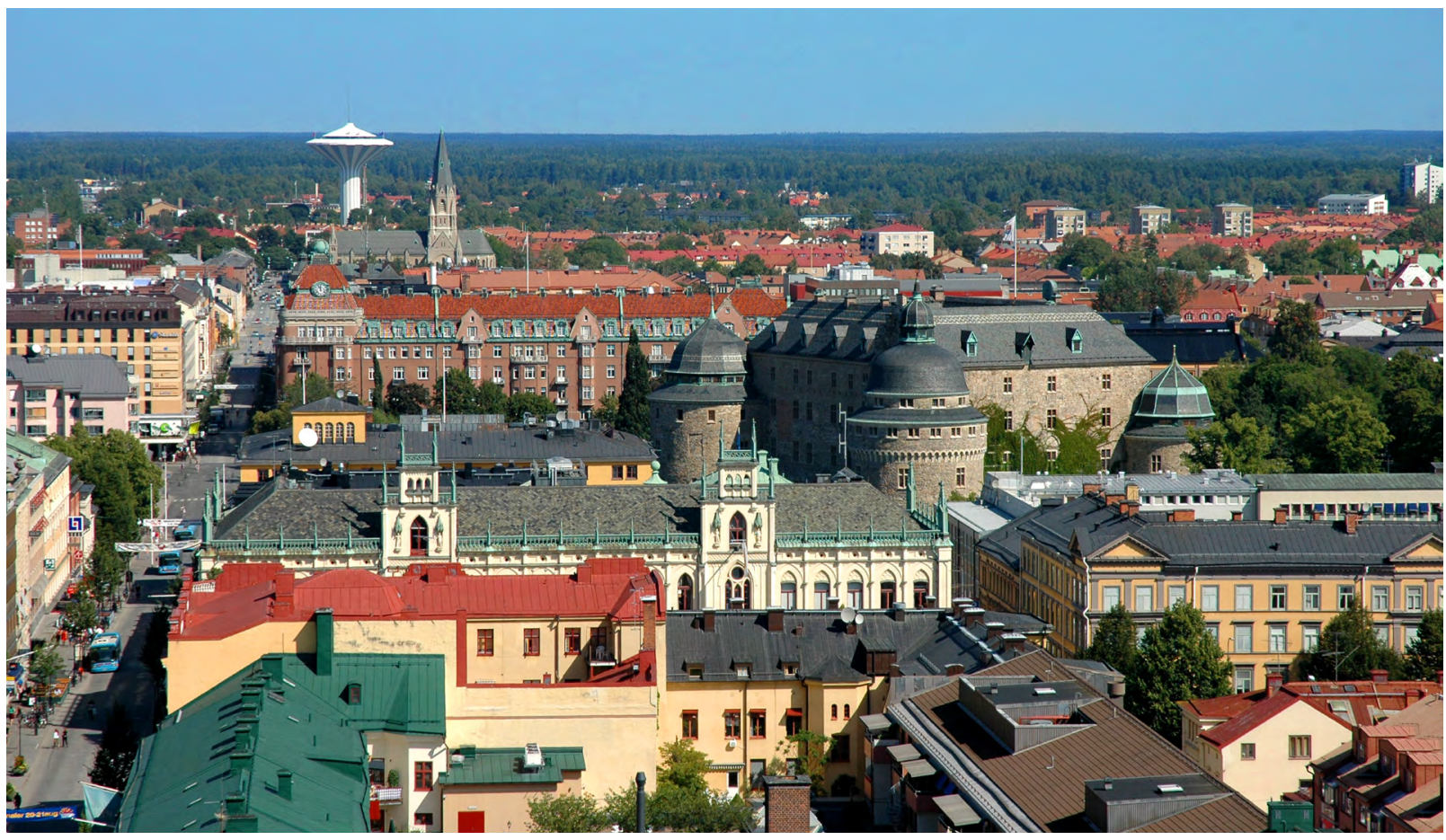

Källa: Fredrik Kellén, Örebro kommun

- Invånarantal: 150,291 (2018)

- Medeltät kommun. Kärna i den funktionella stadsregionen Örebro

Utgångspunkt: I Örebro initierade den dåvarande kommundirektören arbetet med Agenda 2030 och de globala hållbarhetsmålen 2016. År 2018 deltar alla ledande politiker och tjänstepersoner i det lokala arbetet med hållbar utveckling. Åsikterna om hur arbetet med detta tema ska utföras går dock något isär.

Mål och prioriteringar: Än så länge har Örebro inte tagit fram något hållbarhetsprogram för att kommunicera arbetet med Agenda 2030. Istället integreras arbetet med hållbar utveckling i kommunens egna målområden och den årliga budgeten. Örebro kommuns strategiområden - hållbar tillväxt, människors egenmakt, barns och ungas behov, och trygg välfärd - anknyter alla till flera av hållbarhetsmålen. I likhet med många andra kommuner mäts målen med hjälp av vissa nyckelindikatorer.

Genomförande och resultat: Kommunen mäter hur väl förvaltningarna har klarat av att nå de lokala målen med exakta målvärden och nyckelindikatorer. Varje avdelning har detaljerade beskrivningar över vad som ska göras för att uppfylla de lokala målen. Detta skapar en arbetskultur som är inriktad på hållbar utveckling. En tjänsteperson i Örebro säger: "Alla kommuner vill vara hållbara, men det är svårt att motstå när någon vill göra en stor investering i din kommun, även om det finns risk för att den kommer att skada miljön i det lokala samhället. Det är viktigt att de lokala myndigheterna i sådana fall inte ger vika för frestelsen att gå vidare utan en konsekvensanalys. För att kunna göra det är det viktigt med en tydlig rollfördelning och ett etablerat förtroende i organisationen. Men det är inte något som ett dokument i sig kan skapa." Örebro har även en av högsta andelarna av nya bostäder per 1000 invånare i Sverige och samtidigt ett av de största antalen naturreservat. En förutsättning som möjliggör detta är att aktörer på den privata marknaden betraktas som partners i arbetet med att skapa en hållbar stad, en annan är att den lokala förvaltningen ger tydliga riktlinjer för deras verksamhet.

Nåsta steg: En ny hållbarhetschef har utnämnts och stadsbyggnadsförvaltningen tar fram vidare beslutsunderlag för bland annat genusbudgetering och konsekvensanalys för jämställdhet.

Vad kan andra kommuner lära sig av Örebro? Hur det går att samarbeta med privata och civilsamhällets aktörer med en tydlig rollfördelning, exempelvis inom bostadssektorn. 


\section{Helsingborg (SE)}

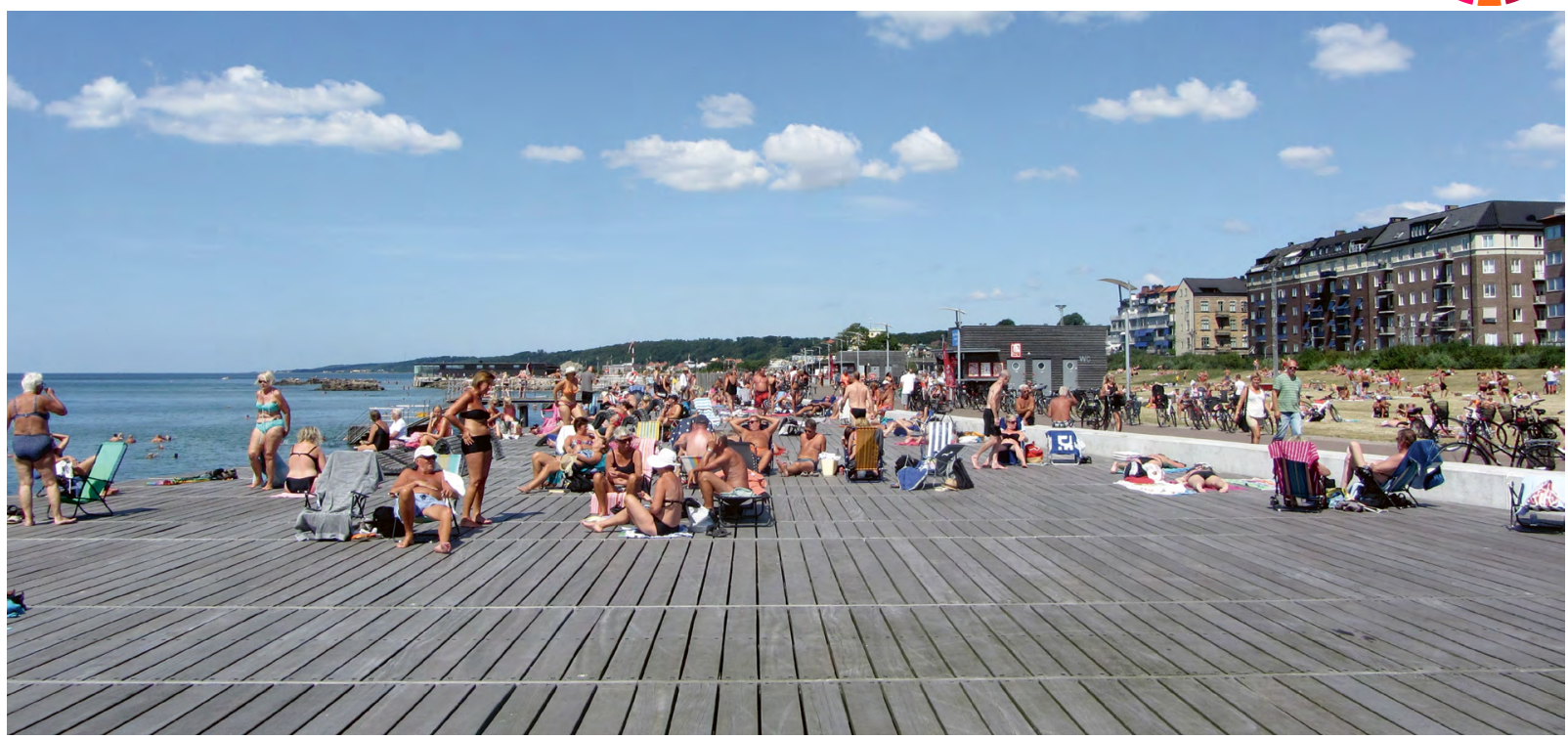

Källa: Sofia Kokacka, fotograf

- Invånarantal: 143,304 (2018)

- Medeltät kommun. Kärna i den funktionella stadsregionen Helsingborg.

Utgångspunkt: Under en revidering av kommunens miljöprogram i slutet av 2014 var signalerna från ledande lokalpolitiker och tjänstepersoner tydliga: programmet måste ta hänsyn till Helsingborgs regionala, nationella och globala kontext. När Agenda 2030 antogs 2015 var det därför helt naturligt att hållbarhetsmålen skulle påverka det nya programmet.

Mål och prioriteringar: Helsingborgs centrala styrdokument, Livskvalitetsprogrammet, antogs 2016 (Helsingborgs kommun 2016). Det fokuserar inte enbart på Agenda 2030, utan innehåller också nationella, regionala och lokala mål för folkhälsa, miljö och hållbar utveckling. Med programmet vill kommunen förbättra de sociala och miljömässiga förutsättningar som människor behöver för att må bra och njuta av en god livskvalitet. Kommunen använder inte termer eller symboler från Agenda 2030 för sin kommunikation; till exempel används begreppet "livskvalitet" istället för "hållbarhet". Trots detta innehåller programmet aspekter från samtliga 17 hållbarhetsmål. Kommunens alla förvaltningar och kommunägda bolag är involverade $i$ att genomföra livskvalitetsprogrammet.

Genomförande och resultat: En så kallad "barnhearing" arrangerades 2017 där kommunens tjänstepersoner och förtroendevalda träffade barn i åldern 5-18 år för att diskutera hållbar utveckling och barnens framtid. En lokal tjänsteperson säger: " $V i$ utför mycket planering och beslutfattande som berör barn, men vi frågar sällan barnen vad de vill. En av mina kollegor har kallat det vi gjorde förut "vuxengissning". Termen är givetvis skämtsamt avsedd, men vi lärde oss mycket av barnhearingen, till exempel fokuserar vi nu mer på utomhusmiljöer för barn."

Helsingborg hade inte något gott rykte när det gällde etnisk, LGBTQ- och könsdiskriminering och större insatser och mer resurser har nu riktats på hållbarhetsmål 5: jämställdhet. Kommunen har organiserat en årlig Pridefestival i flera år i samarbete med en mängd mångfaldsinriktade ideella organisationer. 2018 gavs ansvaret för festivalen helt över till dessa organisationer, vilket visar att kommunen har förtroende för att civilsamhället kan äga processen och evenemanget. Utöver dessa aktiviteter tillämpar kommunen också mål 12 om hållbar konsumtion och produktion genom att sträva efter att inrätta cirkulära system och sluta närings-, kemikalie- och vattencyklerna i sina avfalls- och vattenbolag.

Nåsta steg: Kommunens förvaltningar fortsätter koppla livskvalitetsprogrammet tydligare till Agenda 2030 och hållbarhetsmålen.

Vad kan andra kommuner lära sig av Helsingborg? Hur hållbarhetsmålen kan sammanlänkas med en livskvalitetsplan för den lokala befolkningen. 


\section{Nya Asker (NO)}

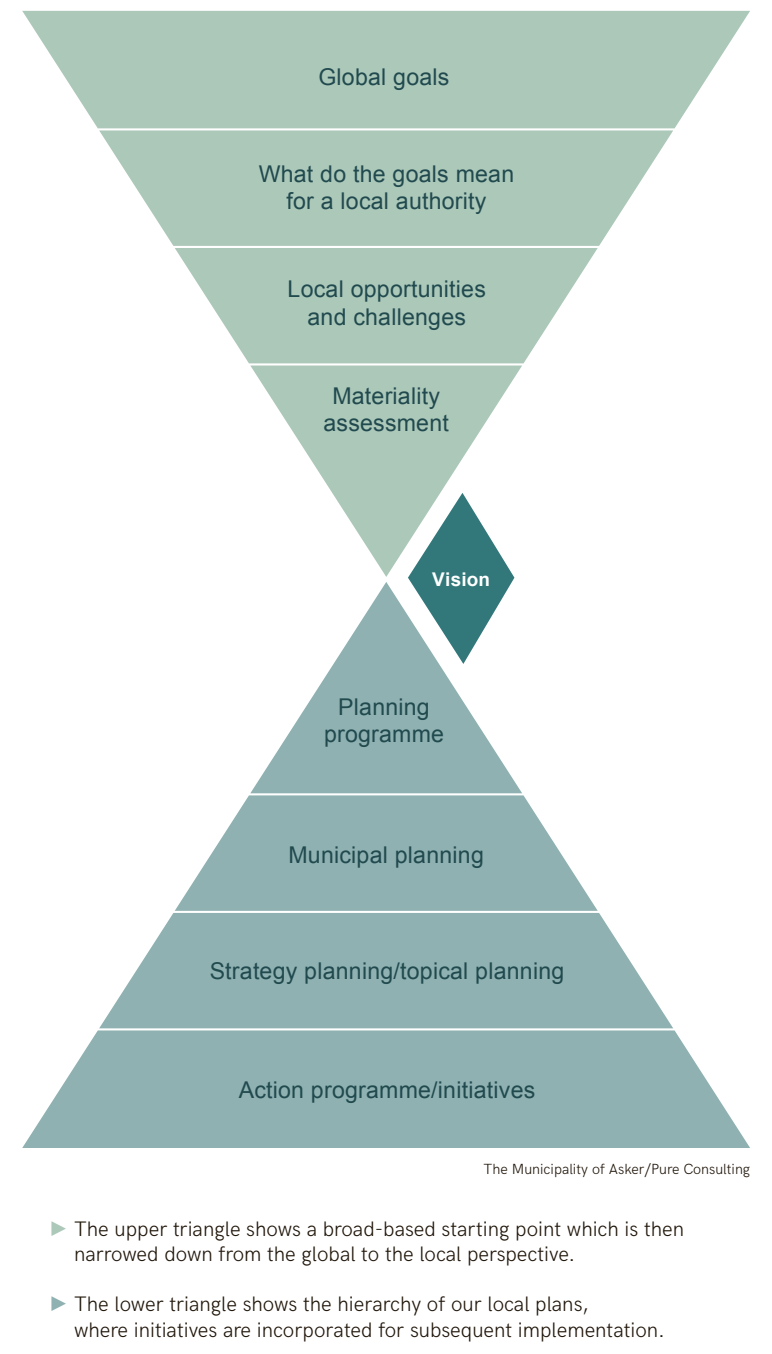

Källa: Asker kommun/Pure consulting

Invånarantal: cirka 93,000 efter sammanslagningen

- Medeltät kommun. Asker och Røyken ingår i den funktionella stadsregionen Oslo.

Utgångspunkt: I början av 2016 undertecknade kommunerna Asker, Hurum och Røyken ett intentionsavtal att sammangå den 1 januari 2020 och en gemensam nämnd (Fellesnemnda) inrättades för att planera sammanslagningen. Nämndens medlemmar enades $i$ ett tidigt skede om att de centrala styrdokumenten för den nya kommunen, som ska heta Asker, bör ligga i linje med Agenda 2030 och de globala hållbarhetsmålen. Intentionsavtalet definierade också kärnvärderingarna som

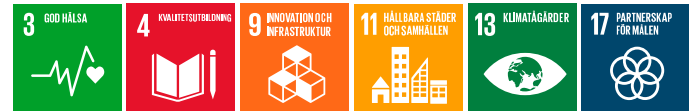

ligger till grund för arbetet i den nya kommunen:

- Bra och likvärdiga tjänster för alla

- Heltäckande och samordnad samhällsutveck-

ling

- Hållbara och ekonomiskt stabila samhällen

- Förstärkt lokaldemokrati.

Mål och prioriteringar: Nämnden diskuterar för närvarande vad Nya Asker kan göra för att hållbarhetsmålen ska uppnås. En viktig slutsats från diskussionerna är att det krävs prioriteringar. Även om alla dimensioner av hållbarhet är nära sammanflätade och gynnar varandra, är kanske inte alla hållbarhetsmål relevanta eller tillämpningsbara $\mathrm{i}$ en lokal norsk kontext. Ett tidigt analysresultat är att specifika implementeringsstrategier kommer att definieras för hållbarhetsmålen 3, 4, 9, 11, 13 och 17. Målen 12 och 16 kan också vara relevanta. Av de 169 indikatorer som FN har definierat för mätning av framstegen mot hållbarhetsmålen, har 84 valts för att följa upp framstegen mot de prioriterade målen i Nya Asker.

Genomförande och resultat: Den gemensamma nämnden planerar hur intentionsavtalet kan formaliseras till en lokal plan för den nya kommunen. Ett metodologiskt verktyg tas fram för att definiera åtgärder som ska vidtas och identifiera vilken sektor som ska leda processen. De tre nuvarande kommunerna identifierar vidare intressenter och aktörer från den privata sektorn som bör involveras. Diskussionerna om det praktiska genomförandet av intentionsavtalet och hur detta kommer att påverka de utvalda hållbarhetsmålen är på ett tidigt stadium. Några projekt har dock redan lanserats.

Nåsta steg: Föranalysen av de prioriterade hållbarhetsmålen, medräknat hur de ska genomföras i Nya Asker, slutfördes i mars 2018 i samarbete med det privata företaget Pure Consulting. Nästa steg är att nämnden ska försöka få heltäckande politiskt stöd för slutsatserna från föranalysen. Arbetet med att ta fram en lokal kommunplan började på hösten 2018 och en första del av rapporten om sociala frågor ska antas i början av 2020. Hållbarhetsmålen kommer därefter att integreras i alla styrdokument. Konkreta projekt och åtgärder ska lanseras för att uppnå målen.

Vad kan andra kommuner lära sig av Nya Asker? Hur hållbarhetsmålen kan användas som vägledning vid kommunsammanslagningar. 


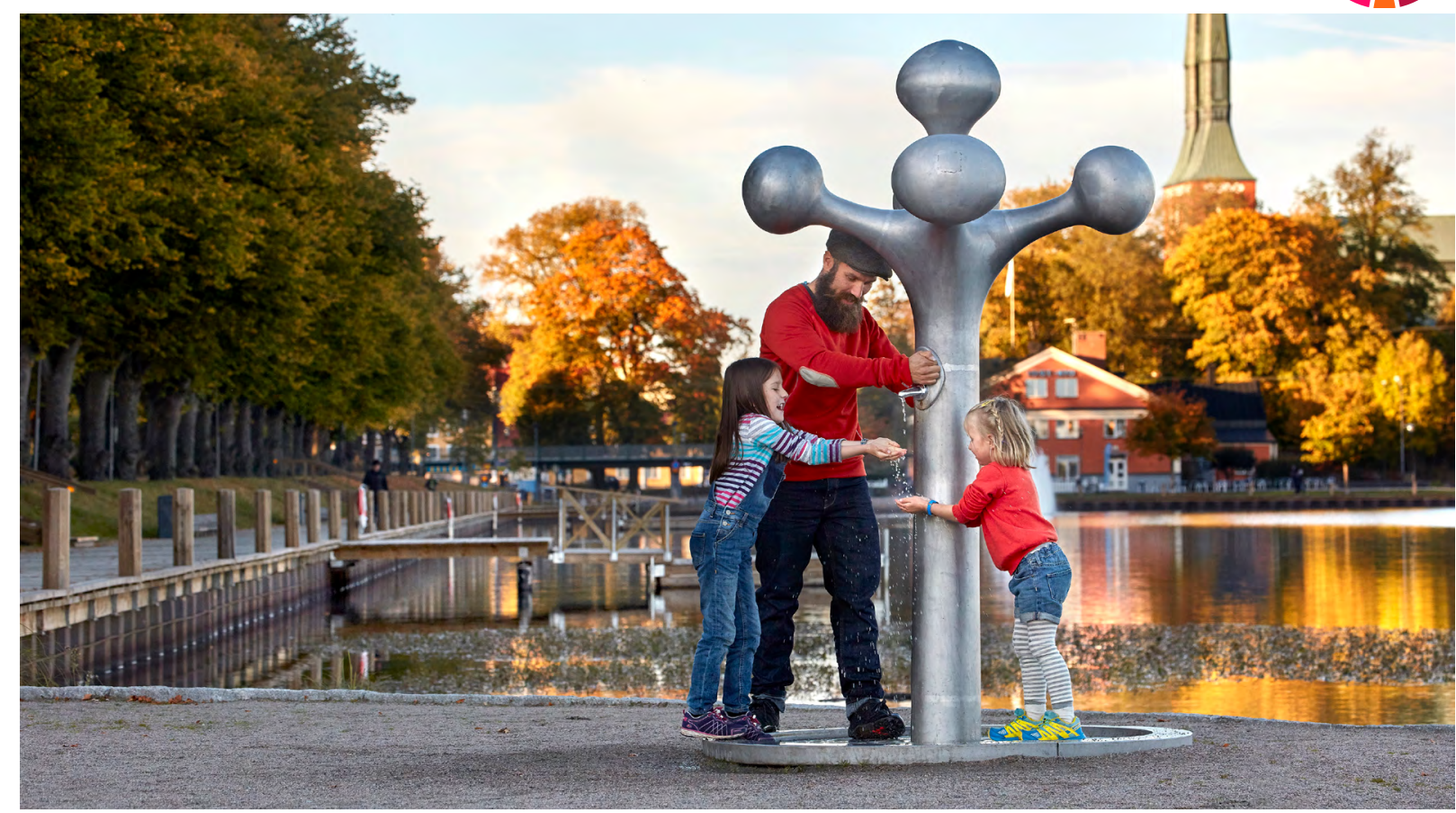

Källa: Mats Samuelsson, fotograf

Invånarantal: 91,060 (2018)

- Medeltät kommun

Utgångspunkt: Växjö kommuns arbete med Agenda 2030 inleddes 2016. Kommunen fick då finansiering från Sida för kommunikation om de globala hållbarhetsmålen. Pengarna användes för att arrangera ett seminarium om Agenda 2030 och hållbarhetsmålen inom kommunen. De förtroendevalda blev då införstådda och på bara fyra dagar inleddes arbetet med att göra Agenda 2030 till ett redskap för insatser i hela kommunen.

Mål och prioriteringar: Kommunen håller på att ta fram ett hållbarhetsprogram där lösningar på specifika utmaningar i Växjö ska definieras med inspiration från hållbarhetsmålen. Enligt en lokal tjänstperson är kommunens arbete med miljöfrågor och miljökvalitet $i$ linje med Sveriges miljömål redan väletablerat tack vare stora insatser sedan 1980-talet. Däremot är det mer troligt att sociala frågor kan bli ämne för politisk debatt under det kommande året när kommunfullmäktige diskuterar och fattar beslut om hållbarhetsprogrammet.

Genomförande och resultat: Arbetet inleddes med en omorganisation inom kommunen. Specialister inom miljö, mänskliga rättigheter, välfärd och häl- sa flyttade till ett Hållbarhetsutskott direkt under kommunens politiska och administrativa ledning. Ett halvdagsseminarium arrangerades 2016 som förde samman lokala politiker, tjänstepersoner, ideella organisationer och privata företag för att skapa en gemensam grund för arbetet med Agenda 2030. Utöver dessa aktiviteter har tjänstepersoner också gått igenom mer än hundra styrdokument, medräknat budgeten, för att se hur de relaterar till hållbarhetsmålen. Under den processen identifierade de ungefär 50 specifika utmaningar som Växjö står inför när det gäller hållbarhetsmålen. Diskussionen om utmaningarna har vägletts av följande frågor: Vilka mål är vi bra på? Vilka mål arbetar vi inte med? Behöver vi göra mer? Nåsta steg: En ny hållbarhetschef har utnämnts och arbetsgrupper tillsatts för att behandla de identifierade utmaningarna med personal från kommunens alla förvaltningar. Fullmäktige ska besluta om de politiska prioriteringarna utifrån dessa arbetsgruppers resultat. Detta är viktiga steg i processen att införa kommunens hållbarhetsprogram i början av 2019.

Vad kan andra kommuner lära sig av Våxjö? Hur seminarier kan arrangeras med lokala företag och ideella organisationer för att planera arbetet med Agenda 2030. 


\section{Gladsaxe (DK)}
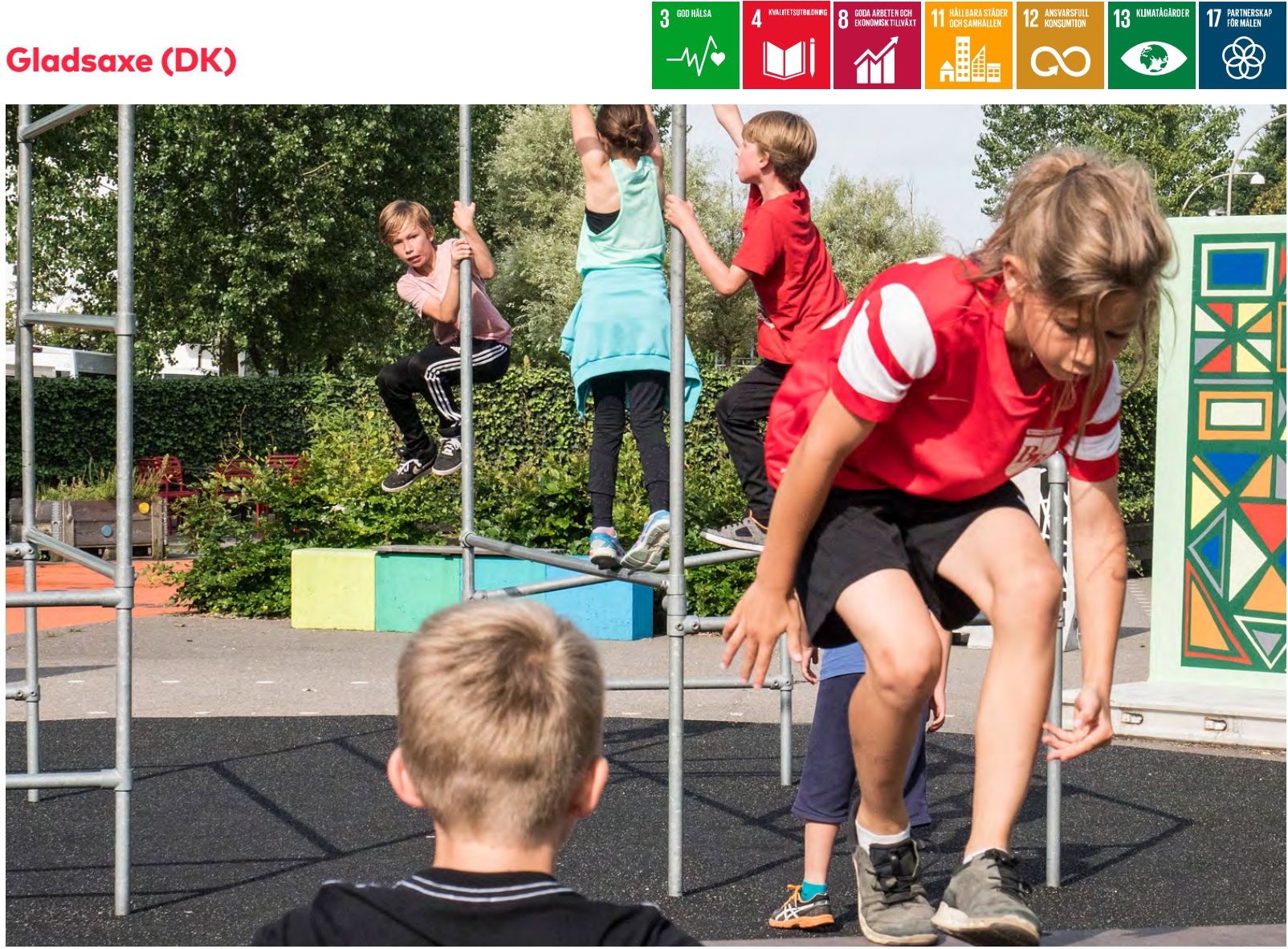

Källa: Gladsaxe kommun

[ Invånarantal: 69,484 (2018)

- Tätbefolkad kommun. Kärna i den funktionella stadsregionen Köpenhamn

Utgångspunkt: Gladsaxe kommun har försökt hitta sätt för att öka samarbetet och dialogen mellan de olika förvaltningarna. Hållbarhet identifierades som ett relevant horisontellt tema som kunde användas för att föra avdelningarnas arbete närmare varandra. Agenda 2030 och de 17 hållbarhetsmålen ansågs vara ett idealiskt ramverk för detta angreppssätt, eftersom de ligger i linje med kommunens vision som fokuserar på social, miljömässig och ekonomisk balans. Kommunen använde Agenda 2030 som inspiration för att ta fram ambitiösa lokala mål. Dessa mål har integrerats i Gladsaxes nya kommunstrategi.

Mål och prioriteringar: Kommunfullmäktige tog fram den nya kommunstrategin med sex lokala mål 2017 och 2018. Målen är bland annat att göra Gladsaxe grönare och mer levande, att främja hälsa och välfärd bland människor i alla åldrar och att erbjuda alla likvärdiga möjligheter. Gladsaxestrategien 2018-2020 beskriver samtliga mål samt insatser som behövs för att uppnå dem (Gladsaxe
Kommune 2018). Vart och ett av de sex målen är uttryckligen länkade till ett eller flera hållbarhetsmål för att framhålla hur Gladsaxe genom sitt arbete med lokala mål bidrar till att uppnå hållbarhetsmålen på global nivå.

Genomförande och resultat: Strategin har inte ännu antagits, men är i skrivande stund (sommaren 2018) ute på en offentlig remissrunda. Många pågående åtgärder i kommunen anknyter dock redan till de sex lokala målen. Ytterligare program och projekt med syftet att nå de lokala målen och bidra till de globala hållbarhetsmålen kommer att starta när kommunfullmäktige har antagit den nya strategin.

Nåsta steg: Gladsaxe utvecklar för närvarande indikatorer för att mäta framstegen i att uppnå de sex lokala målen. De kommer att hjälpa såväl tjänstepersoner i den offentliga förvaltningen som lokala invånare och företag att följa upp genomförandet av strategin på lång sikt. Lokala aktörers deltagande kommer att utgöra ett viktigt element för att målen ska uppnås.

Vad kan andra kommuner lära sig av Gladsaxe? Hur hållbarhetsmålen kan länkas till och integreras i en kommunstrategi samt hur fokus på lokala prioriteringar kan bidra till att de globala målen uppnås. 


\section{Kópavogur (IS)}

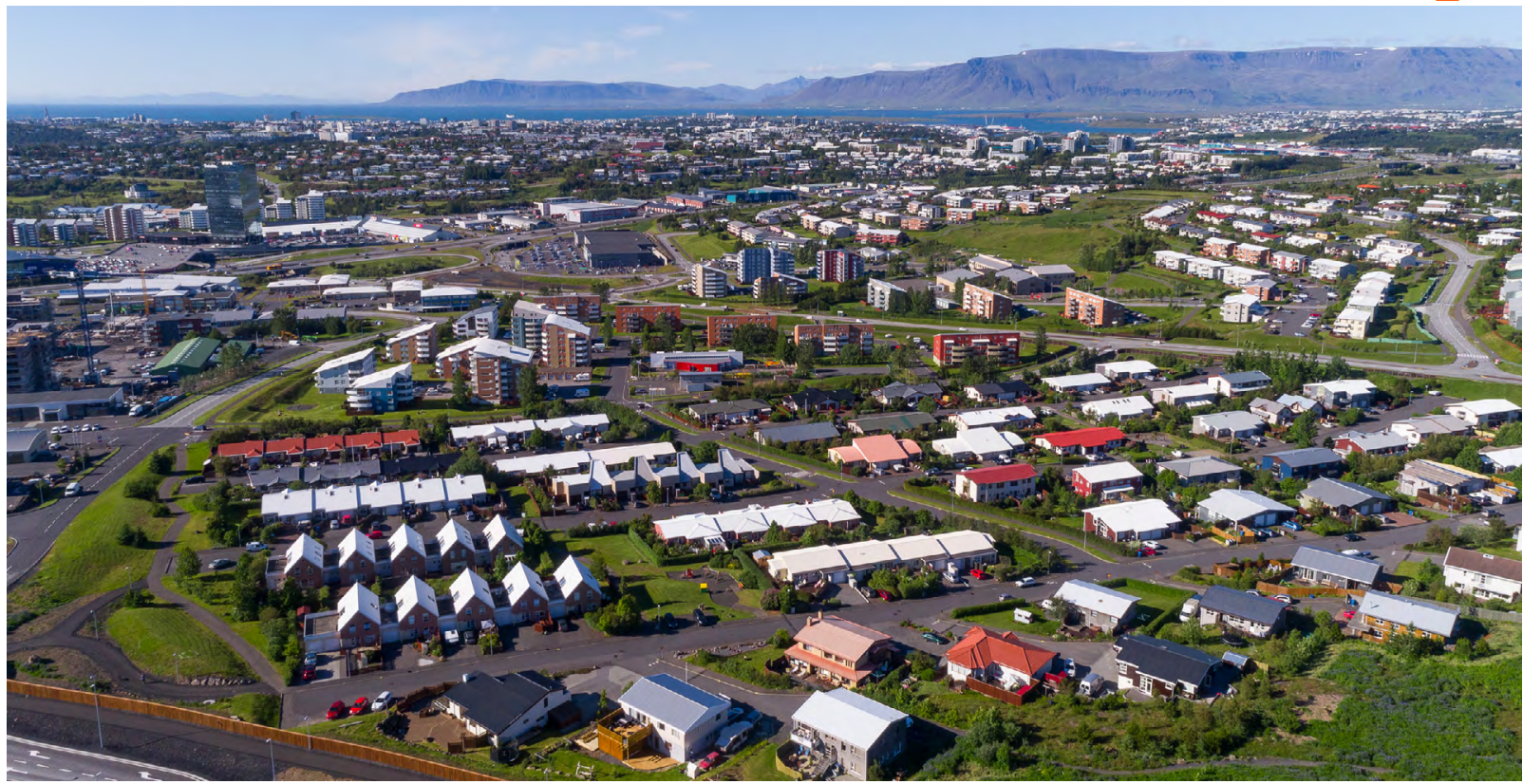

Källa: Kópavogur kommun

Invånarantal: 35,970 (2018)

- Medeltät kommun

Utgångspunkt: Kópavogur implementerar Agenda 2030 genom sin kommunstrategi och ett stort antal indikatorer som mäter sociala framsteg. En delegation reste till Texas och New York 2014 för att utforska hur andra offentliga myndigheter utför långsiktig strategisk och ekonomisk planering. Femtio anställda från kommunens olika förvaltningar tog därefter fram en ny strategi utifrån idéer man fått under resan. Strategin definierar nu en vision som utgör grunden för all strategisk planering.

Mål och prioriteringar: För Kópavogur var utvecklingen av effektiva resultatindikatorer ett nyckeluppdrag och en utmaning i fråga om strategisk planering. Kommunen använde ett index för social utveckling, Social Progress Index (SPI), framtaget av den USA-baserade icke vinstdrivande organisationen Social Progress Imperativ för detta ändamål. SPI är ett holistiskt mätinstrument baserat på ett antal indikatorer för sociala och miljömässiga resultat. Dessa organiseras kring tre dimensioner av social utveckling: grundläggande mänskliga behov, förutsättningar för välbefinnande och möjligheter. SPI kan användas för att beskriva en befintlig situation och för att fastställa politiska prioriteringar. Det kan även användas för jämförelse med andra samhällen, städer eller länder. Kópavogur använde SPI för att kartlägga sina utmaningar och få bättre insikter $\mathrm{i}$ social utveckling, politiska prioriteringar och det lokala samhällets specifika behov. Kommunen kopplade därtill indexet till hållbarhetsmålen för att visa hur Kópavogur bidrar till att de globala målen uppnås genom att främja sociala framsteg lokalt. SPI beskriver resultat som anknyter till 16 av de 17 globala hållbarhetsmålen.

Genomförande och resultat: I samarbete med SPI:s huvudkontor och den lokala SPI-partnern, Cognitio, definierade Kópavogur 56 lokalt relevanta indikatorer för att mäta de tre dimensionerna av sociala framsteg. Alla anknyter till ett eller flera hållbarhetsmål. För att hantera dessa indikatorer och underlätta behandlingen av data utvecklade kommunen programvara baserad på befintlig statistik. Med hjälp av programmet kan anställda, invånare och andra följa upp Kópavogurs resultat. Nåsta steg: I april 2018 gav kommunen ut "Kópavogurs resultattavla", en publikation som visar Kópavogurs aktuella prestationer enligt de 56 indikatorerna (Haraldsson, Friðriksson och Jónsdóttir 2018). Det nyvalda kommunfullmäktige fortsätter att genomföra den lokala strategin och formellt grunda sina mål på hållbarhetsmålen. Fullmäktige vill därför att alla förvaltningar gör upp strategiska planer för hur de ska uppfylla hållbarhetsmålen i sitt arbete.

Vad kan andra kommuner lära sig av Kópavogur? Hur olika index och indikatorsystem, som Social Progress Index, kan användas för att mäta framstegen mot hållbarhetsmålen. 


\section{Kristiansund (NO)}

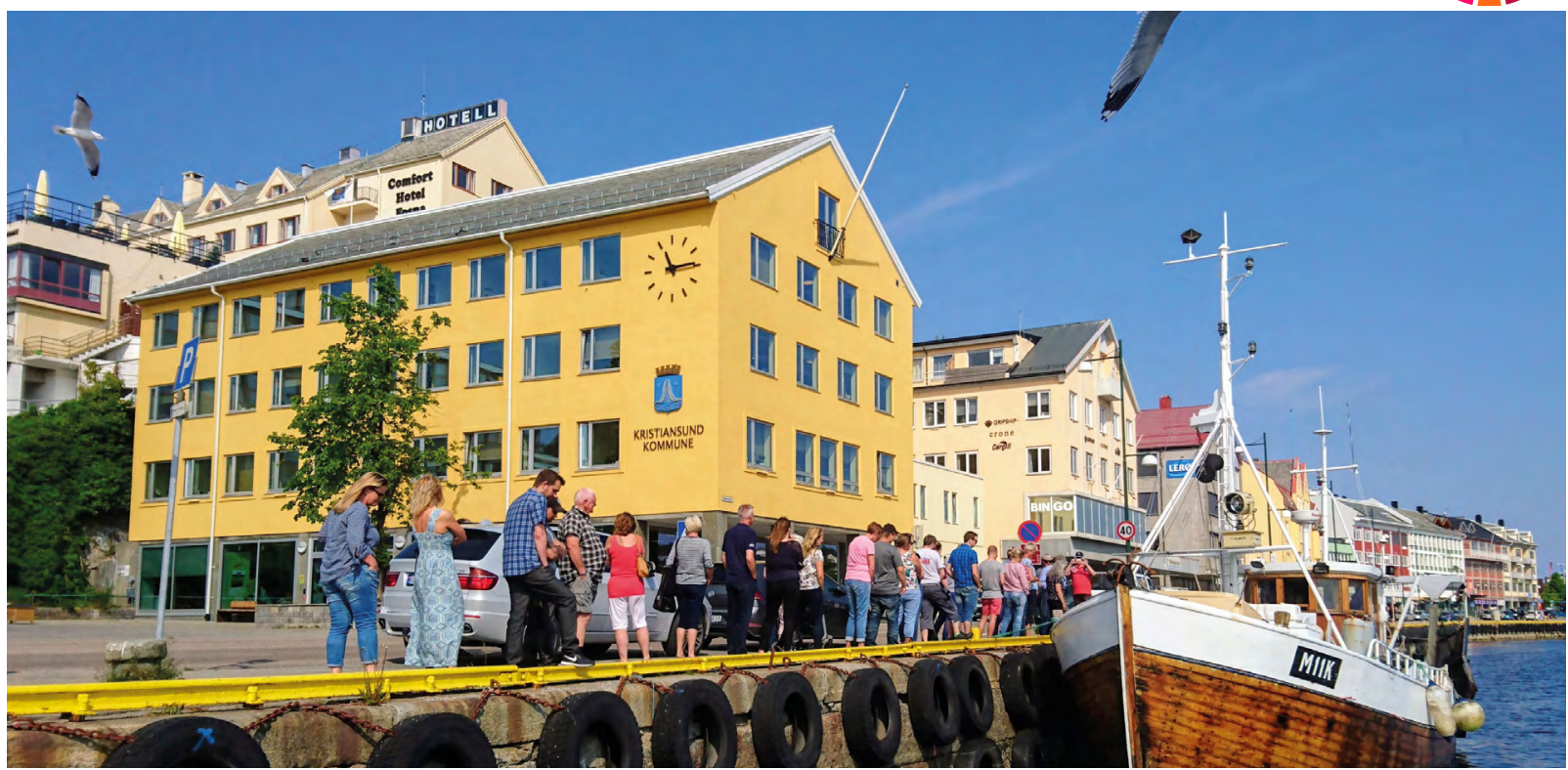

Källa: Odd-Arild Bugge, fotograf

- Invånarantal: 24,300 (2018)

- Medeltät kommun

Utgångspunkt: Den nya ordföranden för Kristiansunds kommunfullmäktige, vald 2015, betonade hållbarhetsmålen starkt. I det sammanhanget blev fullmäktige och kommunadministrationen allt mer medvetna om att de saknade tillgång till grundläggande uppgifter för att följa upp sina hållbarhetsinsatser. Kommunen sammanförde 2016 olika verksamhetsledningssystem vilket gav möjlighet att se över datakällor och indikatorer. Agenda 2030 hade antagits året innan, så tidpunkten var perfekt för att integrera hållbarhetsmålen i det nya systemet.

Mål och prioriteringar: Utifrån Agenda 2030 har kommunen tagit fram 12 skräddarsydda lokala mål som ska uppnås fram till 2030. Dessa mål inbegriper element från alla 17 globala hållbarhetsmål och är följande: god hälsa, god utbildning, infrastruktur, mindre ojämlikhet, hållbara städer och samhällen, havsrummet, samarbete, lokal kunskapspotential, offentlig ekonomi, urbanisering, grön övergång, och hållbart arbetsliv. Kommunen använde en anpassad version av SMART-modellen för målformulering för att identifiera och prioritera sina mål. Enligt modellen ska varje mål vara:

- Specifikt: Målen måste vara exakta och konkreta.

- Mätbart: Framstegen mot målet måste kunna kvantifieras.
Accepterat: Målen måste vara viktiga, relevanta och avspegla en gemensam vision.

- Realistiskt: Målen måste kunna uppnås med de tillgängliga resurserna.

- Tidssatt: Målen måste ha en tidsram för när de ska uppnås.

Genomförande och resultat: Åtagandet med målen formaliserades i kommunens handlingsprogram 2018 som fastställer budgeten för året och innehåller en ekonomiplan för perioden 2018-2021 (Kristiansund Kommune 2017). Utifrån programmet tas specifika handlingsplaner fram för var och en av kommunens avdelningar. Alla 12 mål är relevanta för varje avdelning.

De 12 lokala målen och motsvarande indikatorer är inbyggda i Kristiansunds verksamhetsledningssystem. Företaget Stratsys levererade programvaran för uppföljningen av framstegen. Kristiansund strävar även efter att engagera invånarna genom positiva scenarier, ett koncept som kommunen kallar "framtidsbilder". Framtidsbilderna är uppbyggda runt fyra kärnvärderingar som beskriver staden år 2030: SMART - KLOK MODIG - VARM.

Nåsta steg: Nästa steg i Kristiansund är att styra handlingsprogrammet genom den politiska processen och anta specifika handlingsplaner för varje sektor som ska omsätta visionen i praktiken.

Vad kan andra kommuner låra sig av Kristiansund? Hur hållbarhetsmålen kan inbyggas i verksamhetsledningssystem och hur invånarna kan engageras med hjälp av positiva scenarier. 


Kemi (FI)

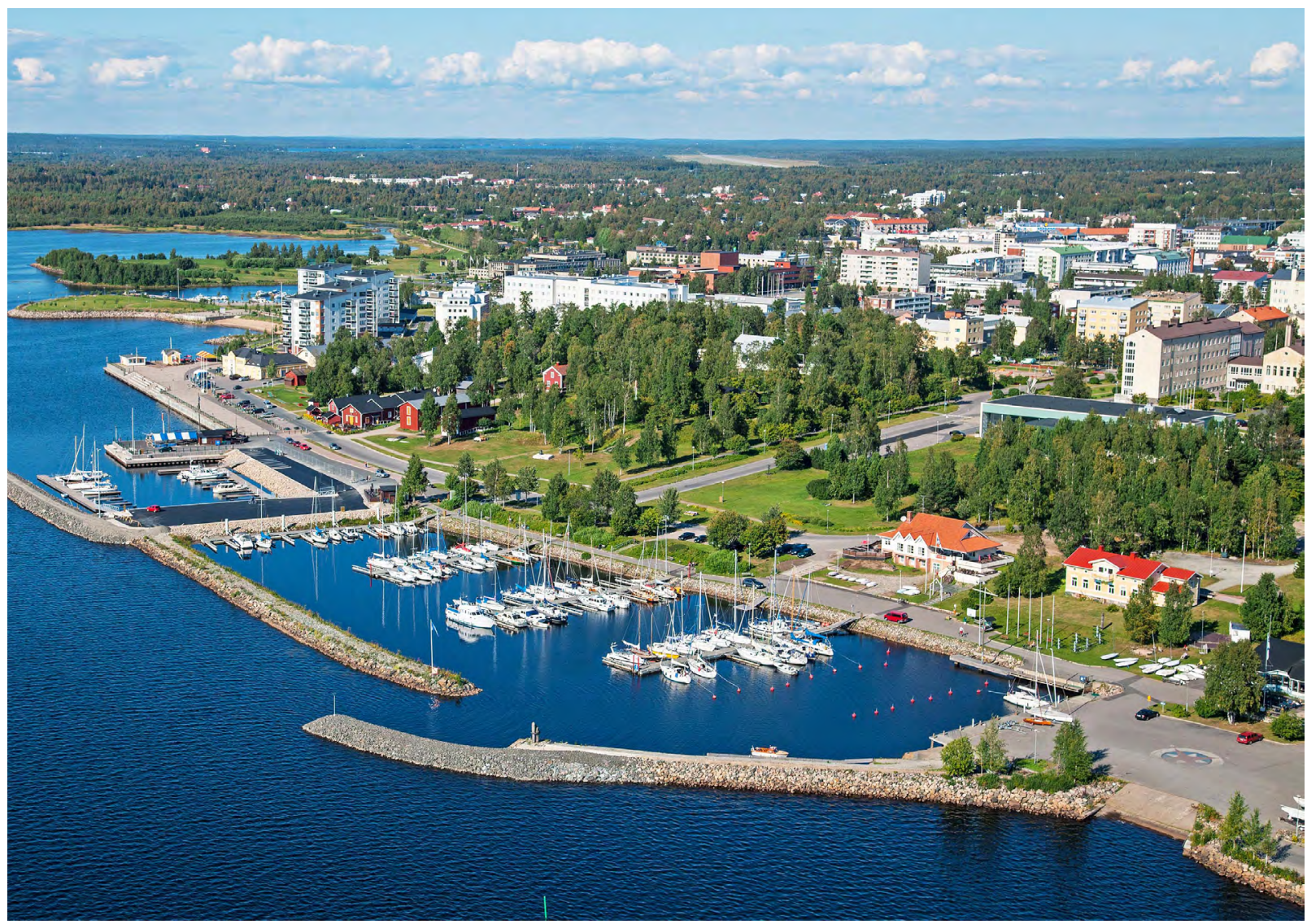

Källa: Kemi kommun

Invånarantal: 21,256 (2018)

- Medeltät kommun

Utgångspunkt: I mars 2019 firar Kemi sitt 150-årsjubileum. Med anledning av detta har kommunen tagit det ambitiösa beslutet att ansöka om ISO 14001-certifiering. Den ges till organisationer med ett miljöledningssystem som uppfyller höga internationella standarder. När Kemi insåg att många av aktiviteterna som sammanhänger med ISO 14001 även är relevanta för genomförandet av Agenda 2030, beslöt sig kommunen för att kombinera dessa två.

Mål och prioriteringar: Kemi strävar efter att öka medvetenheten om hållbarhetsfrågor inom de lokala förvaltningsavdelningarna och bland invånarna samt främja en resurseffektiv affärskultur inom sin egen organisation. Detta mål utgör kärnan för kommunens nya strategi "Ett grönt och hållbart Kemi" som nyligen tagits fram och antagits av stadsfullmäktige. Strategin anknyter till Agenda 2030 och inom ramen för den ska specifika hållbarhetsmål väljas årligen. Kommunen priorit- erar dessa hållbarhetsmål i sitt arbete. I december 2017 beslöt stadsfullmäktige att arbetet 2018 ska fokusera på mål 3: hälsa och välbefinnande, mål 9: hållbar industri, innovationer och infrastruktur, och mål 11: hållbara städer och samhällen.

Genomförande och resultat: Som sin första konkreta åtgärd har Kemi på Finlands webbplats Commitment2050 åtagit sig att minska plastanvändningen. För att uppnå detta mål har staden förbundit sig att undvika inköp av plastprodukter och istället hitta biobaserade alternativ. Staden ska också öka sina insatser för att återanvända IT-utrustning och uppmuntra sin personal att undvika plastprodukter och att återvinna mera.

Nåsta steg: Under de kommande månaderna fokuserar Kemi starkt på att genomföra de förändringar som behövs i förvaltningen och organisationen för att uppfylla ISO 14001-standarderna. Flera åtgärder som anknyter till de tre prioriterade hållbarhetsmålen planeras också.

Vad kan andra kommuner lära sig av Kemi? Hur det går att starta i mindre skala och genomföra Agenda 2030 genom att fokusera på några hållbarhetsmål i taget. 


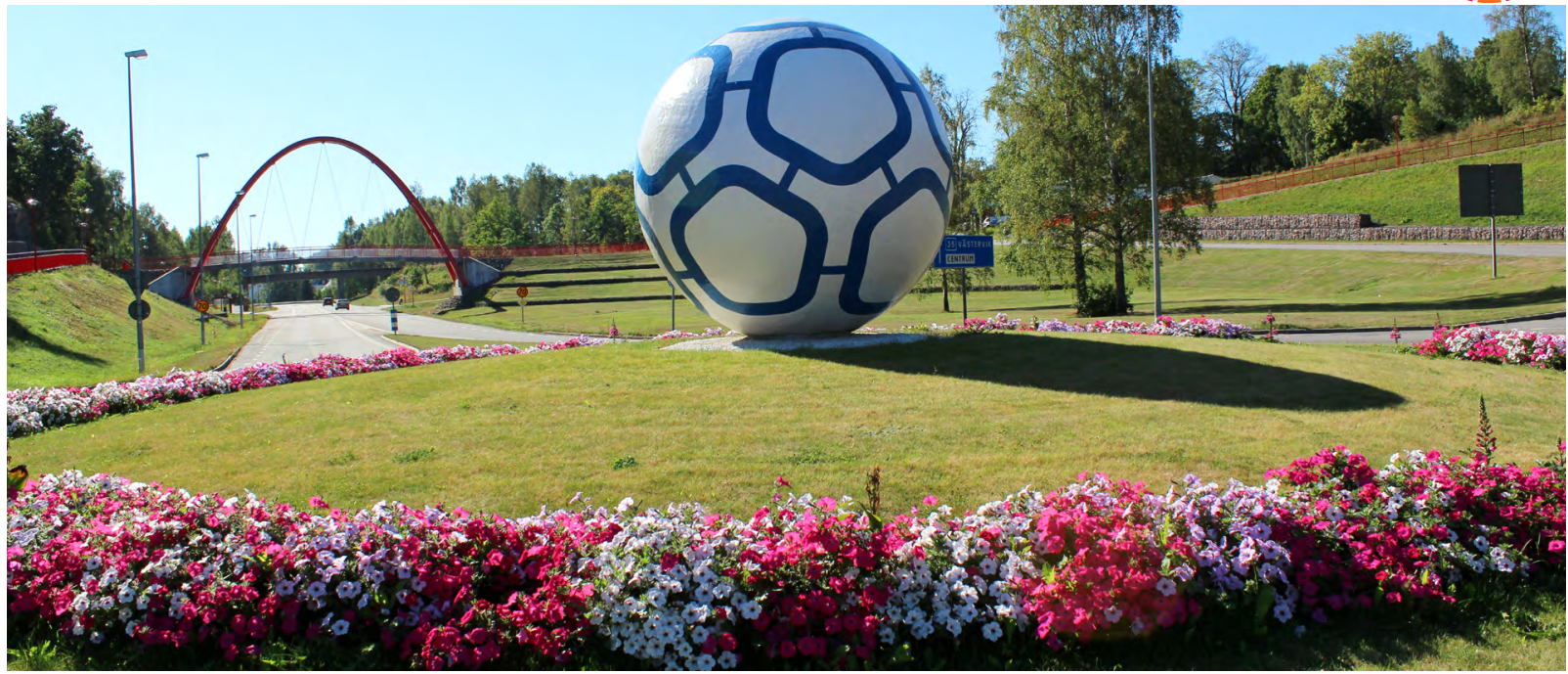

Källa: Ellen Rudholm

- Invånarantal: 11,631 (2018)

- Medeltät kommun. Kärna i den funktionella stadsregionen Linköping

Utgångspunkt: Arbetet med Agenda 2030 i Åtvidaberg inleddes när miljökontoret uppdaterade miljöprogrammet i slutet av 2015 och början av 2016. Under den processen blev tjänstepersonerna medvetna om Agenda 2030 och föreslog att ett hållbarhetsprogram borde tas fram. Kommunfullmäktige godkände förslaget.

Mål och prioriteringar: Hållbarhetsprogrammet togs fram utifrån Agenda 2030, Sveriges miljökvalitetsmål och Sveriges folkhälsomål. Kommunens tjänstepersoner arrangerade workshoppar med chefer från alla förvaltningar. Utgångspunkten där var Agenda 2030 och hållbarhetsmålen, men deltagarna skulle också identifiera prioriteringar och utmaningar inom sina respektive sektorer. Workshopparna anpassade hållbarhetsmålen till Åtvidabergs lokala kontext med hänsyn till kommunens storlek och organisationsstruktur. Slutprodukten är Åtvidabergs hållbarhetsprogram som innehåller fem hållbarhetsfaktorer: ett tryggt och robust samhälle, en hållbar konsumtion och resursanvändning, en energieffektiv och fossilfri kommun, en kemikaliesmart kommun, en kommun som vårdar och utvecklar natur- och kulturvärden (Åtvidabergs kommun 2016). Kommunfullmäktige antog hållbarhetsprogrammet innehållande dessa hållbarhetsfaktorer i december 2016 och alla kommunens förvaltningar arbetar nu med dem.
Genomförande och resultat: De fem hållbarhetsfaktorerna i programmet är långsiktiga mål och vart och ett av dem har specifika delmål som ska uppnås fram till 2020. Åtvidaberg har även ett instrument för mätningen av hållbarhetsprogrammets genomförande. Det har tagits fram för att förklara hur varje förvaltning ska arbeta mot målen och förbättra sina resultat årligen. Framstegen mot att uppfylla de lokala målen är kopplade till Åtvidabergs årsredovisning. Kommunen arbetar med att integrera hållbarhetsprogrammet fullt ut i budgeten.

Som del av hållbarhetsfaktorn "ett tryggt och robust samhälle" har ett lyckat samarbete mellan en förskola och ett äldreboende startats. Det sammanför olika generationer och möjliggör nya vänskaper utan någon extra kostnad. En gång $\mathrm{i}$ månaden besöker barnen de äldre och de lär känna varandra genom konst, slöjd och lekar. Åtvidaberg betraktar den här typen av samarbete som särskilt viktigt i nordiska samhällen, där flera generationer sällan bor tillsammans i samma hushåll. Nåsta steg: De 17 hållbarhetsmålen nämns inte explicit i Åtvidabergs hållbarhetsprogram, men enligt lokala tjänstepersoner finns målen alltid $i$ bakgrunden och de arbetar på att länka uppfyllandet av lokala mål till de globala hållbarhetsmålen. Nästa steg är större insatser för att engagera lokala företag och ideella organisationer i hållbarhetsarbetet.

Vad kan andra kommuner låra sig av Åtvidaberg? Hur det går att utveckla ett hållbarhetsprogram som involverar kommunens alla förvaltningar. 


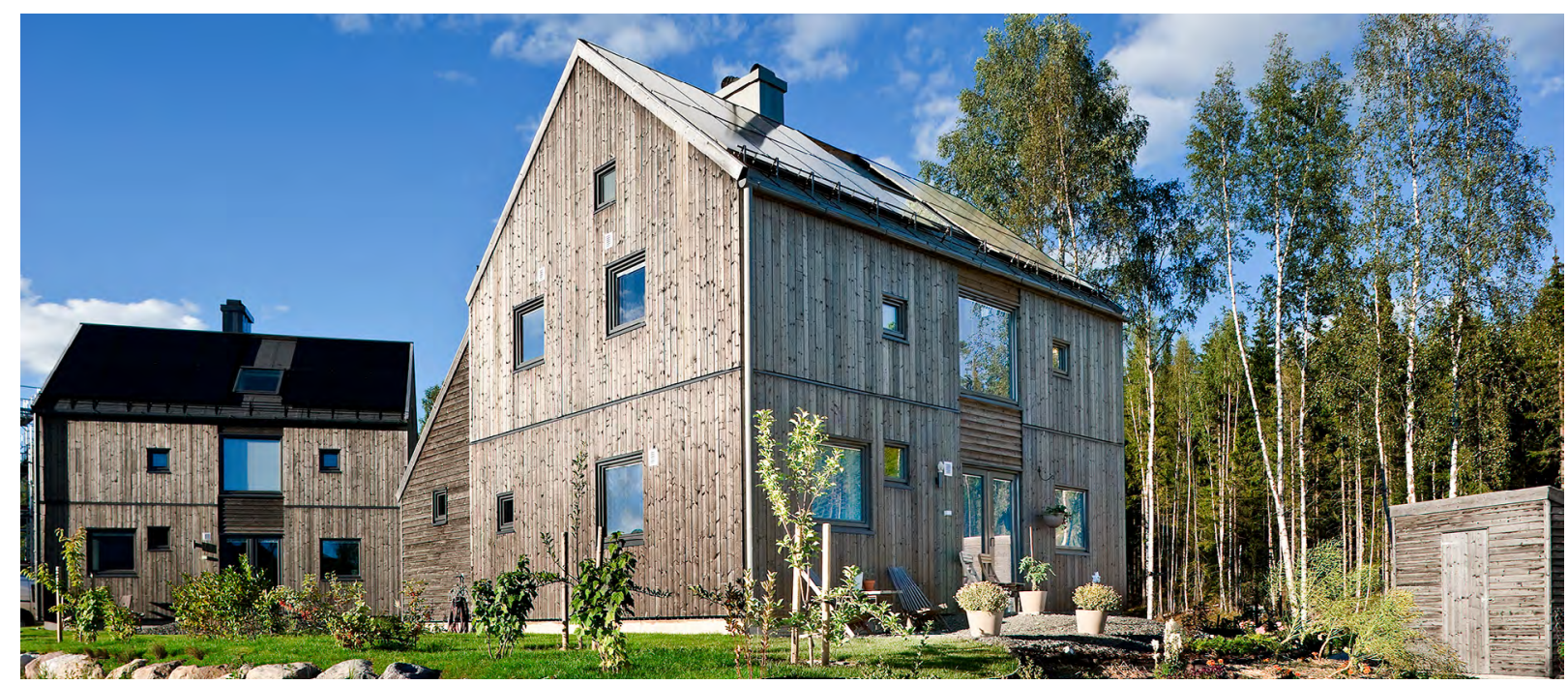

Källa: Hurdal Økolandsby

Invånarantal: 2,903 (2018)

- Medeltät kommun

Utgångspunkt: Kommunen vill föra fram Hurdal som "den hållbara dalen". Visionen är delvis inspirerad av Dag Kittlaus, grundaren av företaget som uppfann Apples röstassistent Siri. Han hade idén att bygga en "Silicon Valley" baserad på hållbarhet nära Oslos flygplats Gardermoen. Den var avsedd som en mötesplats för pilotprojekt och testning med fokus på framtiden, vetenskap, kunskap och hållbarhet. Hurdals kommunfullmäktige beslöt 2014 att kommunen ska vara en ledstjärna i att skapa ett smart hållbart samhälle och slog fast att kommunen "skapar ett hållbart samhälle, som är koldioxidneutralt eller bättre, har ekonomisk tillväxt och tillför invånare och besökare ökad livskvalitet". Avtalen över politiska gränser som behövdes för att kunna ta itu med utmaningarna ingicks 2015. Hurdal implementerar nu Agenda 2030 genom sin kommunplan och sina hållbarhetsmål och alla kommunens förvaltningar deltar i arbetet. Mål och prioriteringar: Hurdals kommunplan konstaterar att "kommunen ska lägga $\mathrm{FN}$ :s hållbarhetsmål som grund för sitt arbete, särskilt inom markanvändning och samhällsplanering, näringsutveckling och tjänsteproduktion/-utveckling" (Hurdal Kommune 2018). Detta överordnade mål utgör riktlinjen för kommunens hela verksamhet: planering, förvaltning, tjänster och utveckling. Kommunplanens samhällsdel beskriver kommunens lokala hållbarhetsmål. I dessa ingår målet att ta i bruk Hurdals naturliga tillgångar för att skapa företagsutveckling, utveckla hållbara tjänster och prioritera bevarande av biologisk mångfald. Ett eller flera dokument beskriver hur varje mål ska uppnås. Varje mål är också länkat till relevanta hållbarhetsmål. I detta arbete betraktar Hurdal hållbarhetsmålen som sammanlänkade delar av en övergripande helhet. Hållbarhetsmål 11: hållbara städer och samhällen, spelar dock en nyckelroll i kommunplanen.

Genomförande och resultat: En av de specifika åtgärderna som Hurdal redan genomför för att uppnå hållbarhetsmål 11 är att främja grönt boende i utvecklingsprojekt. Konceptet med ekobyar är ett exempel på detta. Det stödjer användningen av gröna material och metoder i byggprocessen och främjar ekologiska livsstilar för invånarna. Ett annat pågående projekt är att bygga en ny hållbar stadsdel i centrala Hurdal. I samarbete med ett privat företag har Hurdal också tagit fram ett ramverk och metodologi för att mäta framstegen i att uppnå de lokala hållbarhetsmålen.

Nåsta steg: Kommunen ska snart ta i bruk den nyutvecklade metodologin för mätning av framstegen mot de uppsatta målen. Individuella handlingsplaner för kommunens samtliga förvaltningar ska tas fram under 2019 för att underlätta genomförandet av kommunplanen. Kommunen letar även aktivt efter partners på annat håll i Norge och utomlands.

Vad kan andra kommuner lära sig av Hurdal? Hur det går att främja grönt boende, till exempel med hjälp av ekobyar. 


\section{Nordiska föregångare i arbetet med Agenda 2030}

\section{Riktade angreppssått}

Denna del beskriver arbetet i kommuner som följer ett riktat angreppssätt $\mathrm{i}$ arbetet med Agenda 2030. Dessa är: Århus (DK), Esbo (FI), Tammerfors (FI), Umeå (SE), Sønderborg (DK), Gotland
(SE), Arendal (NO), Sermersooq (GL), Tórshavn

(FO), Birkala (FI), Mariehamn (AX) och Mosfellsbær (IS).

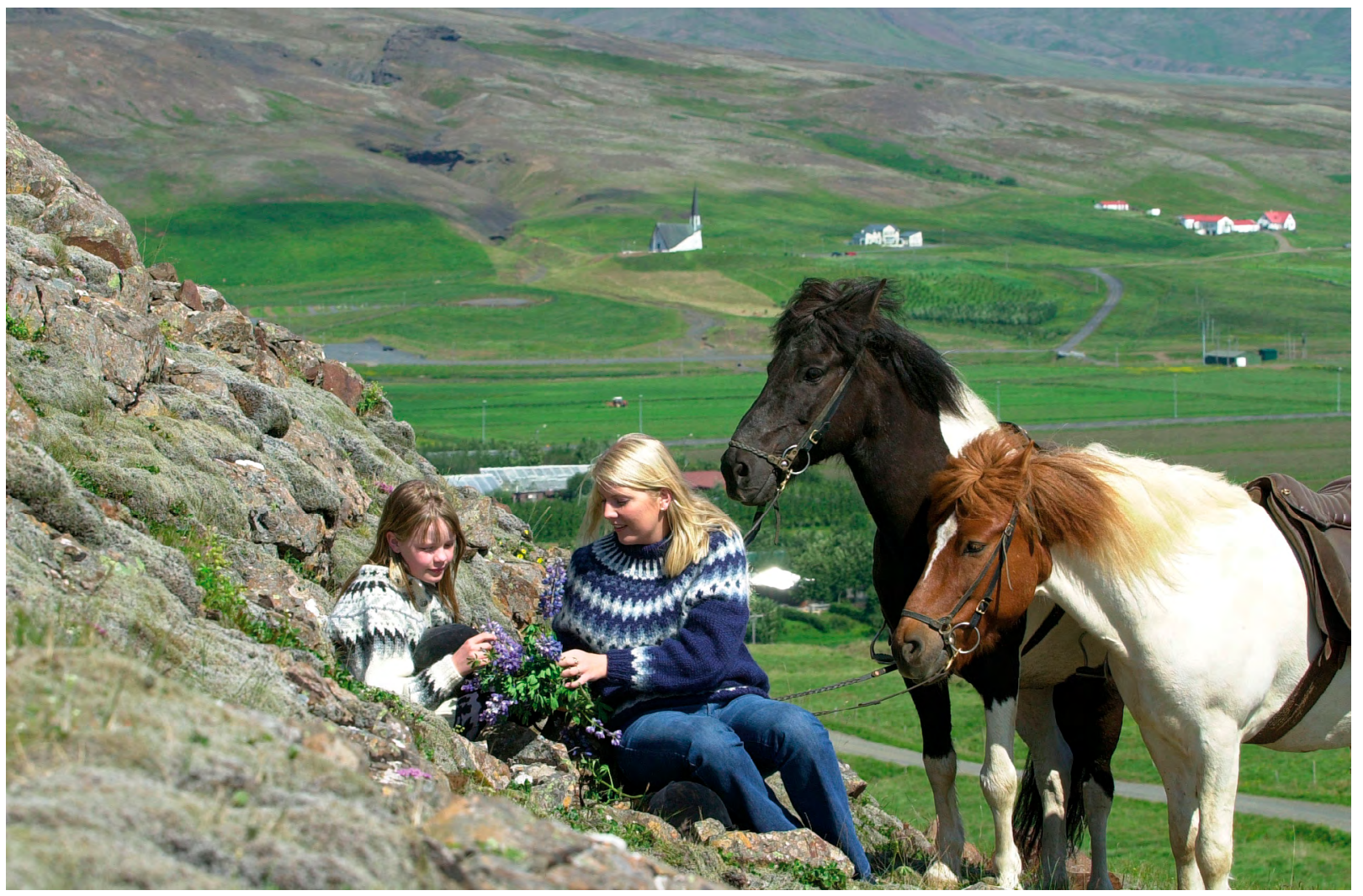

Källa: Mosfellsbærs kommun 


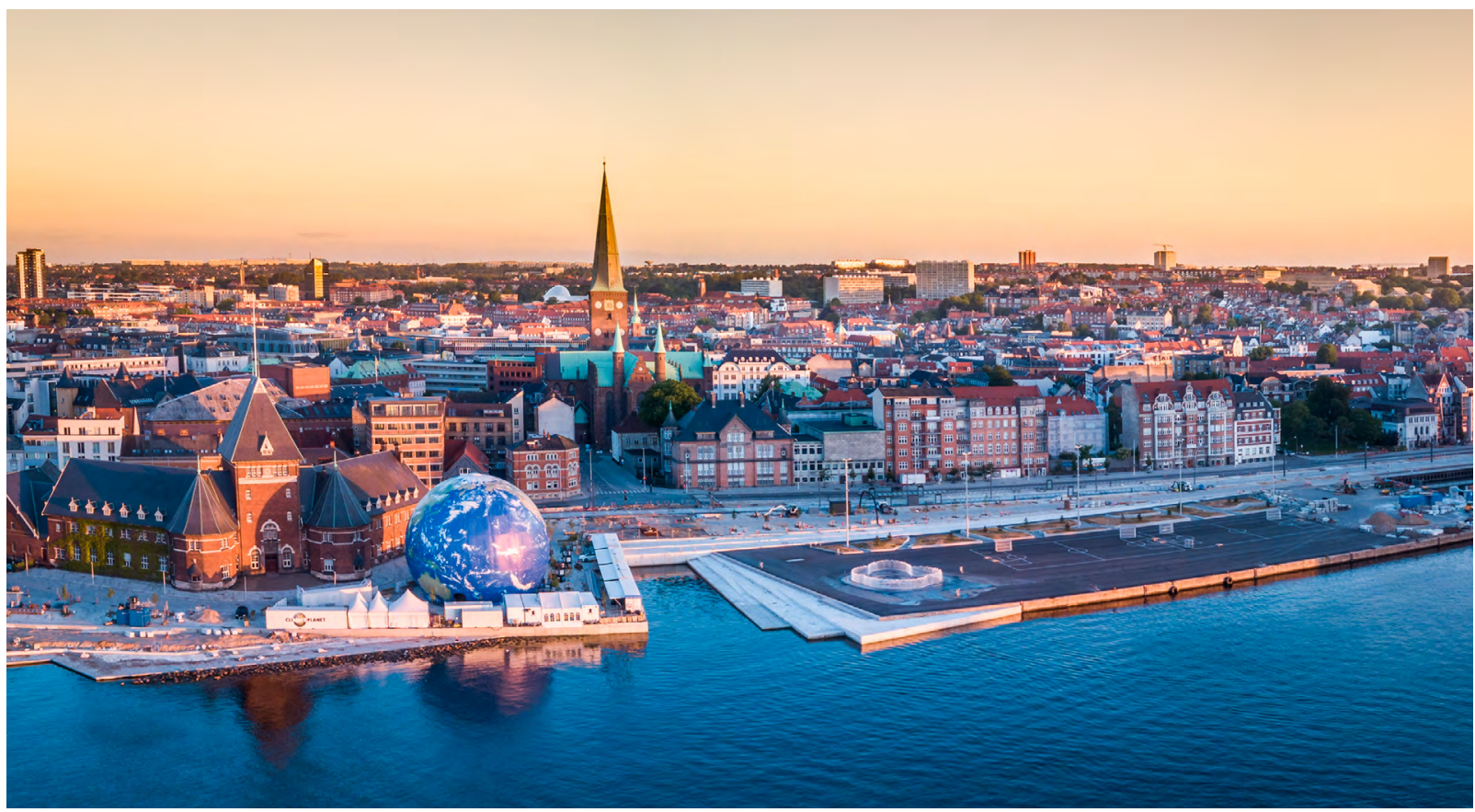

Källa: Århus kommun

Invånarantal: 340,421 (2018)

- Tätbefolkad kommun. Kärna i den funktionella stadsregionen Århus

Utgångspunkt: Århus kommun har länge arbetat aktivt med klimatfrågor. Efter att Agenda 2030 antogs, såg kommunfullmäktige potentiella överlappningar mellan kommunens egna åtgärder och i synnerhet de klimat- och energirelaterade hållbarhetsmålen. En hållbarhetsnämnd inrättades för att identifiera och fördjupa förbindelserna mellan de pågående klimatåtgärderna och de globala målen. Mål och prioriteringar: Så tidigt som 2007 godkände kommunfullmäktige en ambitiös strategi för att göra Århus koldioxidneutralt fram till 2030. Därefter har kommunen antagit ett antal klimatplaner för att först mäta koldioxidutsläppen i kommunen och sedan genomföra steg mot att minska utsläppen. Specifika åtgärder var bland annat att övergå till grön fjärrvärme genom att bränna biomassa istället för kol och renovering av kommunägda byggnader för att förbättra deras energieffektivitet. I sin nuvarande klimatplan för 2016-2020 har Århus definierat milstolpar inom sex områden som ska bidra till att ytterligare minska koldioxidutsläppen: energi, transport, byggnader, industri, lokalt engagemang och tillväxt, och kommunfullmäktiges organisation (Aarhus Kommune 2016). Århus uppsatta mål är bland annat att främja fossilfri trans- port genom att uppmuntra invånare att cykla, gå eller använda kollektivtrafik, uppmuntra industrin att fasa ut fossila bränslen och främja cirkulär ekonomi, öka medvetenheten om klimatfrågor bland allmänheten, och fasa ut fossilbränslebilar i kommunens egen bilpark. Dessa lokala mål anknyter till sex hållbarhetsmål.

Genomförande och resultat: Århus har redan kommit långt i sina insatser för att reducera koldioxidutsläppen. Utöver övergången till grön fjärrvärme och den pågående renoveringen av kommunala byggnader, har Århus öppnat en ny elektrisk lättjärnväg för att tillfredsställa det allt större behovet av kollektivtrafik. Kommunen har också gett ut en grön stadskarta som visar invånare och besökare var det finns hållbara hotell, restauranger och butiker, och inspirerar dem att engagera sig och uppleva det bästa av friluftslivet i Århus.

Nåsta steg: Många åtgärder och projekt som involverar externa intressenter (privata företag, universitet, ideella organisationer) eller andra relevanta partners i och utanför Århus pågår eller startar inom kort. Kommunen vill engagera så många intressenter som möjligt för att säkerställa en solid grund och brett stöd för sitt klimatarbete.

Vad kan andra kommuner lära sig av Århus? Hur det går att få med företag och andra organisationer och marknadsföra deras hållbara arbete, till exempel med en grön stadskarta. 


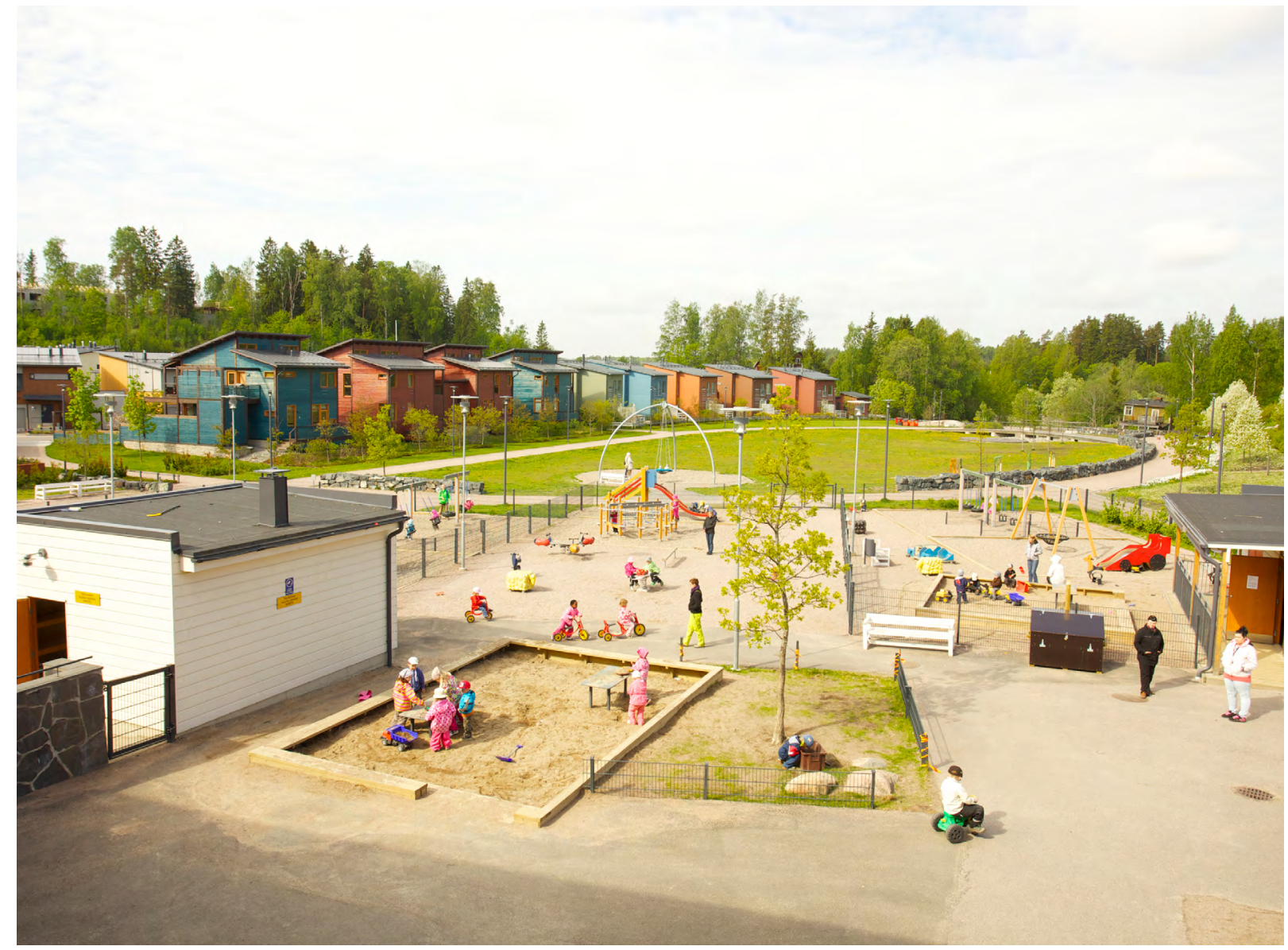

Källa: Esbo stad

- Invånarantal: 279,044 (2018)

- Medeltät kommun. Kärna i den funktionella stadsregionen Helsingfors

Utgångspunkt: Esbo har en lång historia av arbete med hållbarhetsfrågor och rankades 2016 och 2017 som Europas hållbaraste stad av forskningsinstitutet Telos vid universitetet i Tilburg (Zoeteman et al. 2017 och 2016). Agenda 2030 med de 17 hållbarhetsmålen innehåller många teman som hör till prioriteringarna i Esbo, så den betraktades som ett idealiskt ramverk för framtida insatser.

Mål och prioriteringar: Esbo genomför för närvarande fyraårsprogrammet En hållbar stad som inbegriper alla av kommunens förvaltningar. Ett av projekten fokuserar på Agenda 2030 och hållbarhetsmålen. Kommunen identifierar sådana förvaltningsområden där Esbo redan har omfattande hållbarhetsåtgärder och sådana där mer kan göras. Utifrån prioriteringarna som detta re- sulterar i, fastställer alla avdelningar specifika mål och åtgärder inom en nära framtid.

Genomförande och resultat: Esbo har publicerat en ambitiös plan att ingå 100 åtaganden på Finlands Commitment 2050-webbplats. Många av dessa har redan publicerats. Miljöcentralen utvecklar exempelvis en indikator för att mäta ytan på och kontakten mellan grönområden i Esbo, och tillsammans med energibolaget Fortum har kommunen förbundit sig till att all fjärrvärme ska produceras utan nettoutsläpp av klimatgaser senast 2030. Andra åtaganden fastställs och genomförs under de kommande månaderna.

Nåsta steg: Kommunen utvecklar en app inspirerad av framgången med Pokémon Go. Användarna ska lösa uppgifter i kommunen och lära sig om konsekvenserna av klimatförändringen. Appen kommer att användas i undervisningen vid högstadieskolor i Esbo.

Vad kan andra kommuner låra sig av Esbo? Hur det går att undervisa unga om hållbarhet med hjälp av appar och spel. 


\section{Tammerfors (FI)}

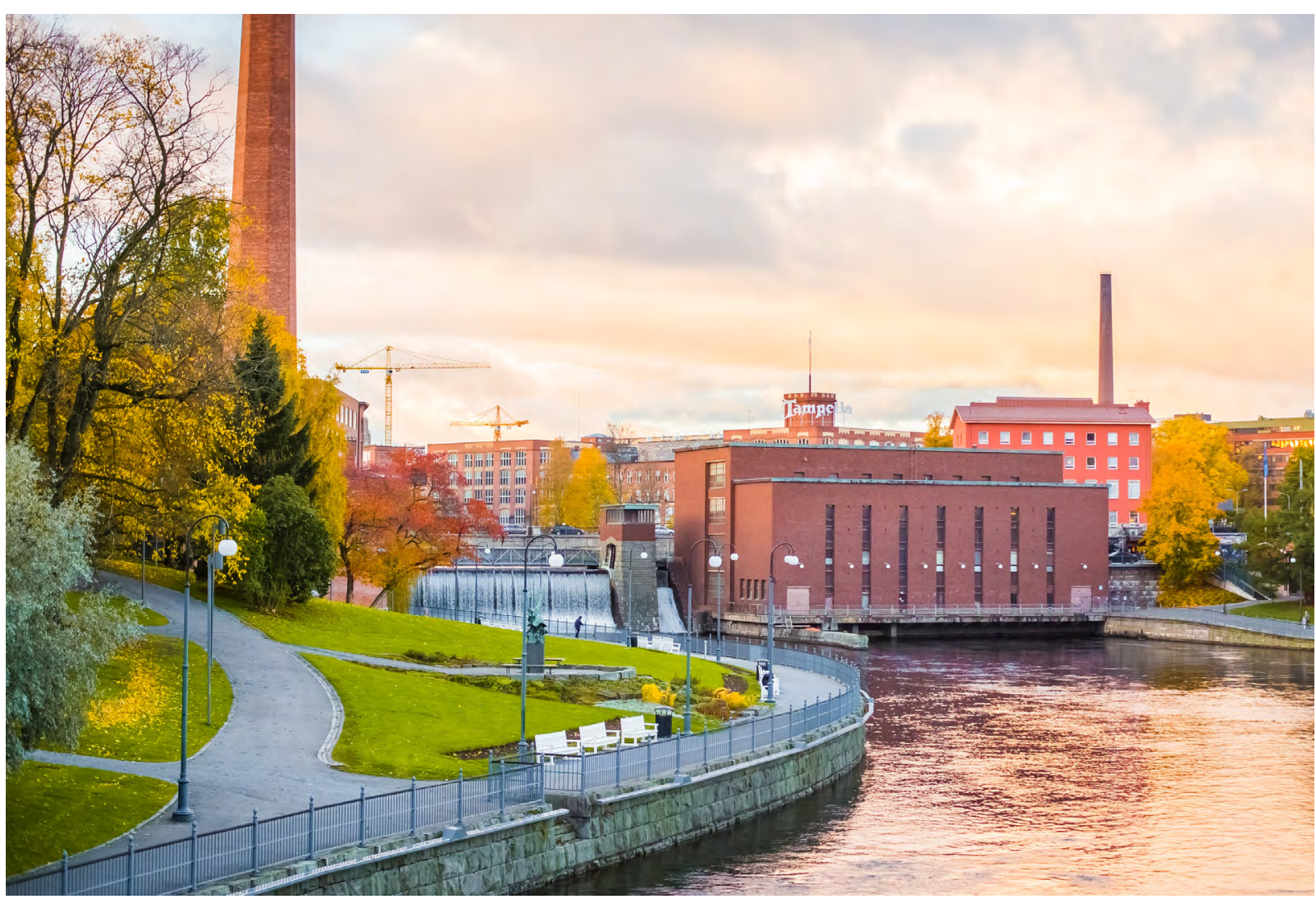

Källa: Laura Vanzo, Visit Tampere

- Invånarantal: 231,853 (2018)

- Medeltät kommun. Kärna i den funktionella stadsregionen Tammerfors.

Utgångspunkt: Tammerfors representerar kommunerna i Finlands kommission för hållbar utveckling vid statsrådets kansli, och har förbundit sig till ambitiösa hållbarhetsmål. Kommunen har en lång historia av att arbeta med initiativ som lokal Agenda 21 och Ålborgstadgan, ett initiativ för hållbara stadsmiljöer som först antogs 1994. Agenda 2030 betraktas som ett användbart instrument för att nå ut till en ny publik och främja hållbarhet inom nya politikområden.

Mål och prioriteringar: Kommunen har beslutat om att prioritera innovationsfrämjande och en resurseffektiv ekonomi samt lägga större vikt vid miljöstandarder och rättvisecertfiering $\mathrm{i}$ sin upphandlingspolicy. Hållbarhetsmål 8: anständiga arbetsvillkor och ekonomisk tillväxt och mål 9: hållbar industri, innovationer och infrastruktur, är speciellt relevanta för kommunen som har en hög arbetslöshetsnivå och genomgår en process av industriell förnyelse. De lokala myndigheterna anser dock att också de övriga hållbarhetsmålen är relevanta för kommunen. I mars 2017 tillsattes en tvärsektoriell arbetsgrupp för hållbarhet för att främja och evaluera lokala hållbarhetsinsatser i ljuset av de globala hållbarhetsmålen.

Genomförande och resultat: Tammerfors implementerar Agenda 2030 genom Finlands nationella plattform Commitment 2050. Kommunen har publicerat ett åtagande med namnet "Hållbar ekonomi- och innovationspolitik och ansvarsfull upphandling i Tammerfors". Texten definierar kommunens mål och åtgärderna som ska vidtas för att uppnå dem.

Nåsta steg: En del av åtagandet är att kommunens samtliga avdelningar har utmanats att reflektera över hur de kan bidra till hållbarheten i Tammerfors och publicera ytterligare åtaganden på webbplatsen Commitment2050. Kommunen samarbetar också med konsultbyrån Benviroc för att ta fram indikatorer för uppföljningen av arbetet med hållbarhetsmålen.

Vad kan andra kommuner lära sig av Tammerfors? Hur kommunens samtliga förvaltningar kan engageras i arbetet med hållbarhetsmålen genom egna hållbarhetsåtaganden. 


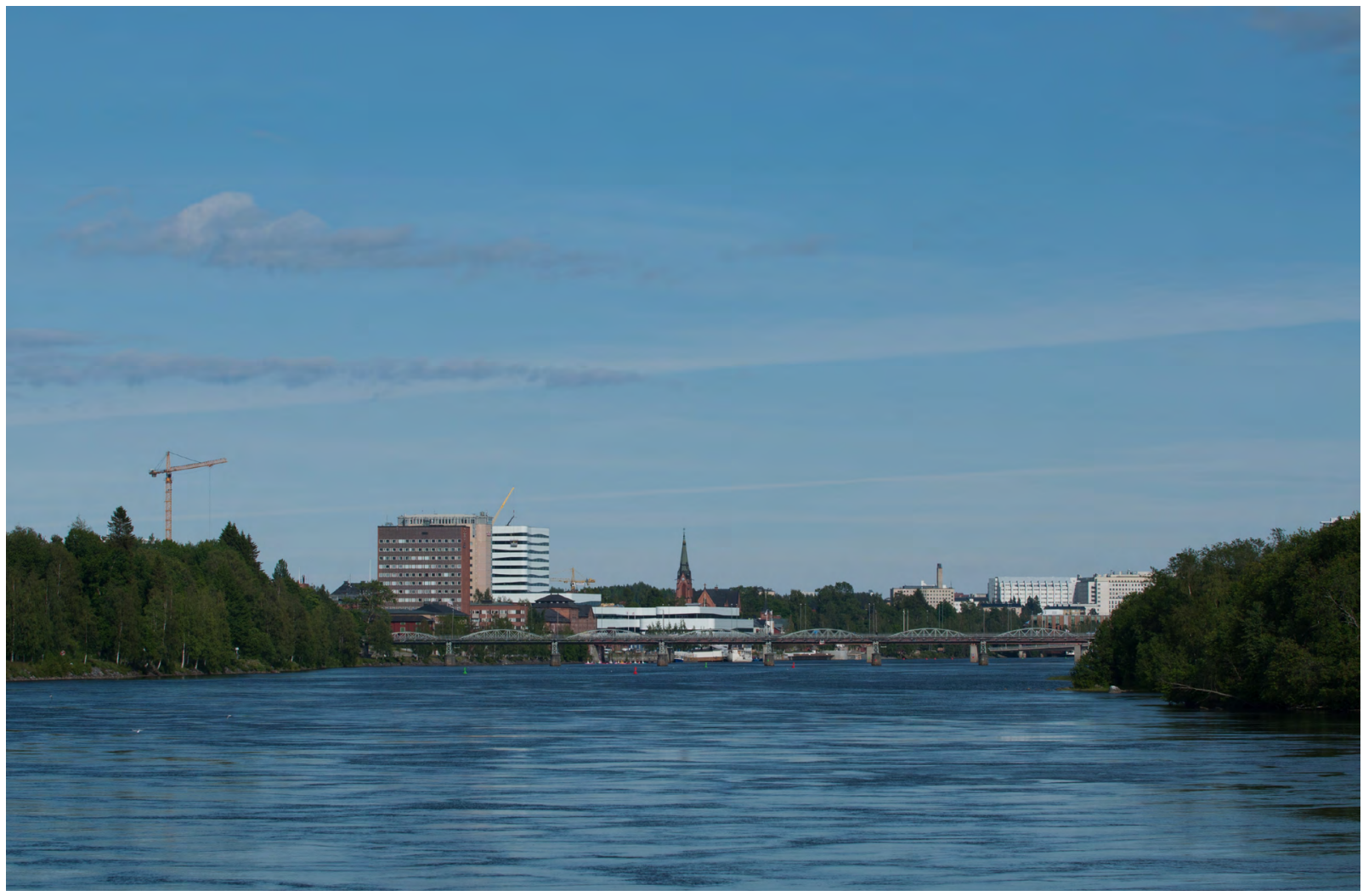

Källa: Peter Steggo, fotograf

- Invånarantal: 125,080 (2018)

- Medeltät kommun. Kärna i den funktionella stadsregionen Umeå

Utgångspunkt: Umeå har en lång historia av arbete med hållbar utveckling, med fokus på jämställdhet, miljö och klimatfrågor. Sedan Agenda 2030 antogs har kommunen arbetat med sektorsintegrering för att göra arbetet med hållbarhetsmålen mer holistiskt. En tjänsteperson säger: "Vi behöver anpassa oss till hållbarhetsmålen och sedan arbeta på ett mer integrerat sätt. Vi måste börja med frågan 'Varför arbetar vi med luftkvalitet?' Så att invånarna kan få en bra livskvalitet. Agenda 2030 binder ihop miljömässiga och sociala aspekter och den fungerar som ett ramverk för lokala initiativ." Mål och prioriteringar: I Umeå var hållbarhetsmål 11 en startpunkt för arbetet med att integrera de globala målen lokalt. Genom att relatera de globala målen till redan pågående arbete inom stads- och infrastrukturplanering kunde kommunen relativt enkelt få ett driv i att anpassa Agenda 2030 till den lokala kontexten.

Genomförande och resultat: Umeå har många olika insatser som sammanhänger med Agenda 2030 och hållbarhetsmålen, allt från folkhälsomålen till dialoger med ungdomar och andra åldersgrupper. Arbetet med hållbar utveckling mäts med verktyget Livsmiljöbarometern som samlar fakta om miljö och natur, jämställdhet, folkhälsa och tillgänglighet. Mer fokuserat arbete med social hållbarhet främjades när kommunen i samarbete med Sveriges Kommuner och Landsting (SKL) anordnade den nationella konferensen Mötesplats social hållbarhet i juni 2017. Umeå kommun arrangerar också årliga möten på en högstadieskola där elever och lokala politiker diskuterar hållbarhet. Kommunens politiska ledare uppskattar mötena som en viktig möjlighet att få ta del av ungas idéer och bekymmer.

Nåsta steg: Kommunen fortsätter analysera hur pågående insatser anknyter till Agenda 2030 och hur de olika hållbarhetsmålen ytterligare kan relateras till varandra och till befintliga lokala mål. Ett nästa steg är exempelvis att fortsatt integrera jämställdhet (hållbarhetsmål 5) i stadsplaneringen (hållbarhetsmål 11).

Vad kan andra kommuner lära sig av Umeå? Hur det går att arrangera diskussioner om hållbarhet mellan politiker och skolelever. 


\section{Sønderborg (DK)}

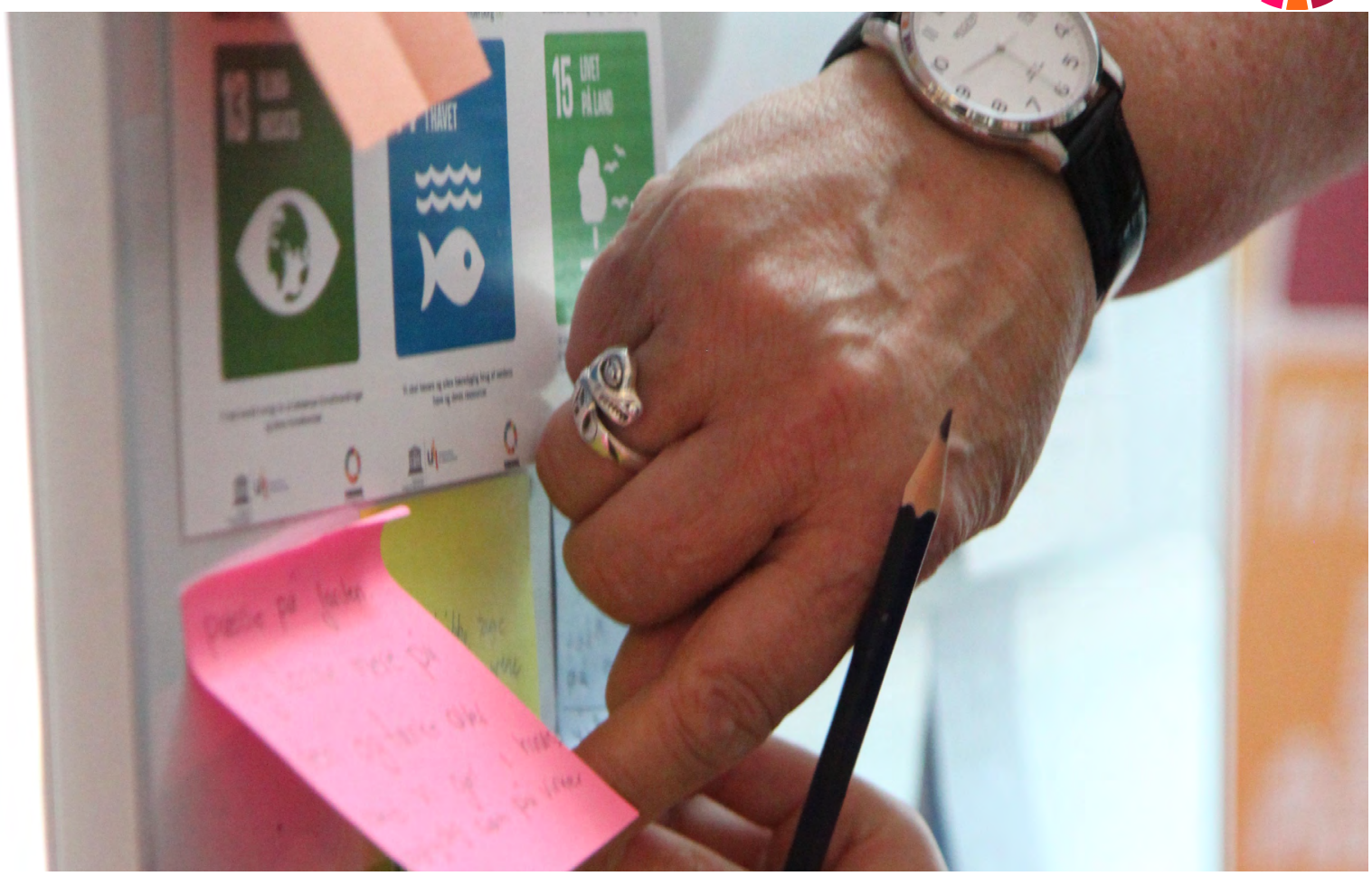

Källa: House of Science, Sønderborgs kommun, Danmark

Invånarantal: 74,650 (2018)

- Tätbefolkad kommun

Utgångspunkt: Sønderborg har en lång historia av av att integrera hållbara lösningar. ProjectZero, med målet att göra Sønderborg till en koldioxidneutral kommun fram till 2029, är ett av de mest framgångsrika och välkända projekten som involverar bostadsrättsföreningar, idrottsklubbar, transportsektorn och lokala företag. Kommunen vill bygga på den här framgången och motivera invånare att vidta åtgärder för hållbarhet. Agenda 2030 betraktas som ett välkommet globalt ramverk att användas för detta arbete.

Mål och prioriteringar: Sønderborg vill uppmuntra lokala invånare att ta initiativ och befrämja deras förståelse av att små steg kan göra skillnad i att tackla globala utmaningar. Det övergripande målet är att uppmuntra 10000 invånare att bli ambassadörer för hållbarhet. För att uppnå detta fokuserar man speciellt på att utbilda elever, studerande och familjer om hållbarhet och de globala hållbarhetsmålen. Ramverket är redan på plats $i$ och med att Sønderborg blev del av Unescos nätverk Learning Cities för aktivt medborgarskap, hållbarhet och livslångtlärande liksom involvering av lokala företag och organisationer.
Genomförande och resultat: Sønderborg har ett tydligt syfte att förstärka kommuninvånarnas engagemang $\mathrm{i}$ hållbarhetsmålen. För att förverkliga det har man tagit hjälp av konsultföretaget Sustainia. Kommunen arrangerar workshoppar och utbildningsveckor om hållbarhetsmålen för barn, ofta i samarbete med lokala skolor. Ett exempel är Sculpture4Kids där barn och konstnärer arbetade med en färgpalett utifrån hållbarhetsmålen för att göra allmänheten mer medveten om målen, ett annat är att lokala skolor deltog i det ambitiösa initiativet 21 mprezs genom att implementera energisparlösningar i skolbyggnaderna för att minska på energiförbrukningen och kostnaderna och samtidigt öka trivseln.

Nästa steg: En webbapplikation planeras för att öka kunskapen om och förståelsen av hållbarhetsmålen; den är samtidigt ett steg i riktning mot målet med 10000 lokala hållbarhetsambassadörer. Fokus på verksamhet och insatser för hållbarhetsmålen bland familjer och föreningar planeras även under nästa år. Sønderborg ska anordna aktiviteter om hållbarhetsmålen med stöd från Sustania och kommer att integrera hållbarhetsmålen $\mathrm{i}$ evenemang på lokala orter.

Vad kan andra kommuner lära sig av Sønderborg? Hur unga kan engageras i diskussionen om hållbarhet genom att ingå starka partnerskap med skolor. 


\section{Gotland (SE)}

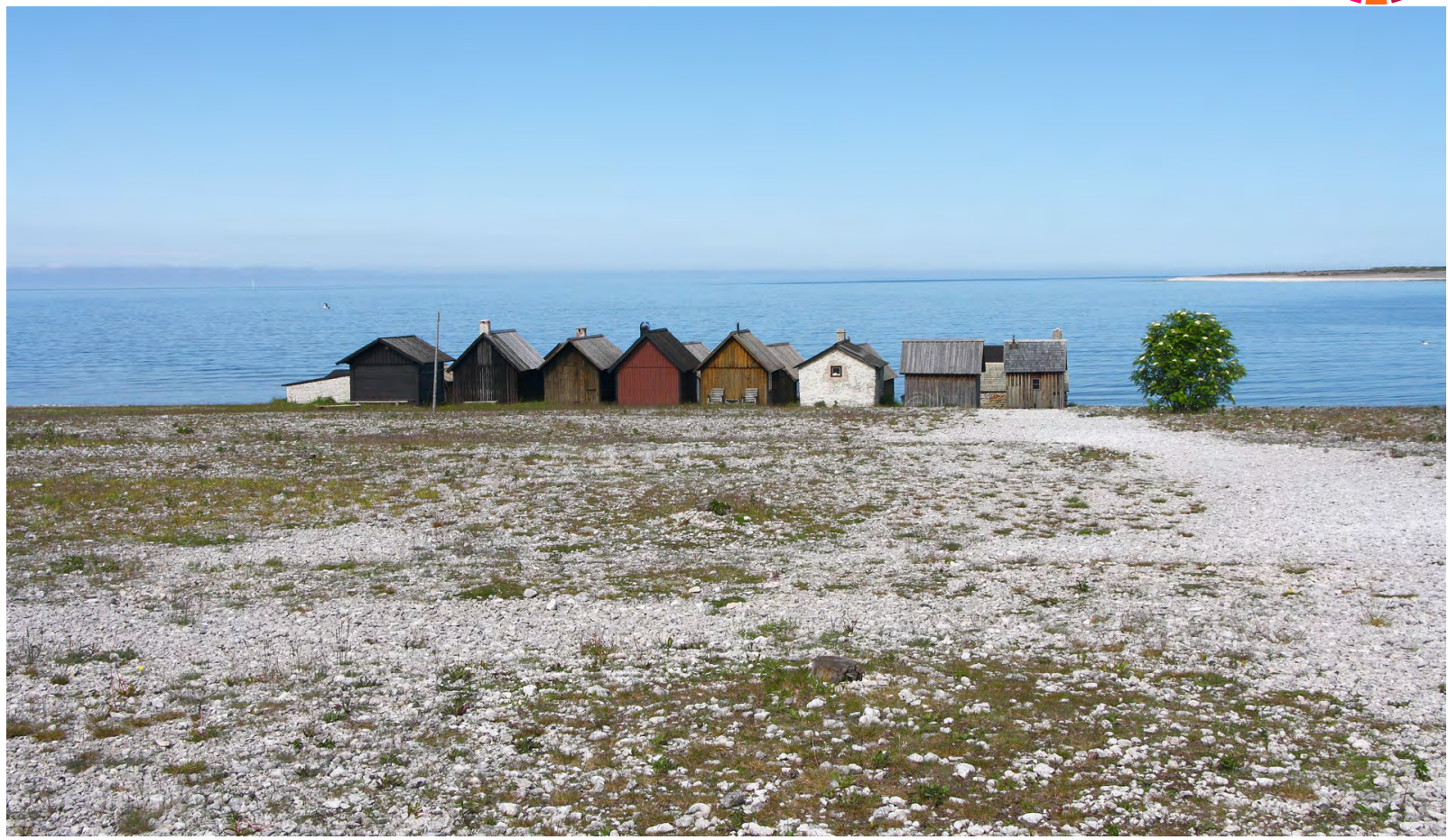

Källa: Schorle, Wikimedia commons, CC BY-SA 3.0

- Invånarantal: 58,595 (2018)

- Medeltät kommun

Utgångspunkt: Inom Region Gotland och Gotlands kommun har ett antal offentliga, privata och ideella aktörer arbetat med Agenda 2030 och hållbarhetsmålen sedan de antogs 2015. Science Center Fenomenalen på Gotland fick 2016 finansiering för kommunikation om hållbarhetsmålen av Sida. Med de här medlen kunde Fenomenalen, som ägs av Region Gotland, skapa en ny interaktiv sektion om de globala målen, ta fram ett minnesspel och skriva en bok för barn och unga om hur alla kan bidra till att hållbarhetsmålen ska uppnås. Mål och prioriteringar: Gotland betraktar samtliga hållbarhetsmål som relevanta och tar mål 17 om globalt partnerskap som kärnan kring vilken de övriga 16 globala målen snurrar. Fastän alla mål är viktiga, innebär Gotlands läge på en ö att de två hållbarhetsmålen om vatten (6 och 14) är särskilt avgörande.

Genomförande och resultat: Gotland har en lång historia av hållbarhetsarbete och har behandlat många av aspekterna i hållbarhetsmålen länge, fastän under andra namn. Regionens tjänstepersoner har också arbetat med sambanden mellan Agenda 2030 och europeiska, nationella och re- gionala mål för att förklara för sina överordnade och politiker hur dessa program interagerar och kan användas tillsammans för regionens styrning. Drivkraften bakom arbetet är viljan att skapa en bättre värld för alla. En tjänsteperson på Gotland påpekar dock att man även måste vara pragmatisk för att få folk att genomföra hållbarhetsmålen. "Det är viktigt [...] att visa att vi arbetar med Agenda 2030. Den är som Europa 2020. Båda är transnationella visionära styrdokument som är i kraft länge och därför är det viktigt att vi i regioner och kommuner integrerar dem $\mathrm{i}$ vårt dagliga arbete."

Nåsta steg: I januari 2018 organiserade Region Gotland, länsstyrelsen och Swedesd, Internationellt center för lärande för hållbar utveckling, en workshop för 70-80 deltagare från privata företag, den akademiska världen, ideella föreningar och offentliga myndigheter. Under workshoppen togs det fram material om hur Gotland arbetar och ska fortsätta arbeta med Agenda 2030. Detta material kommer att utgöra underlag för den nya regionala utvecklingsplaneringen för Gotland som utarbetas under 2019.

Vad kan andra kommuner lära sig av Gotland? Hur man kan skriva en bok för att lära unga om hållbarhetsmålen och hållbarhet. 


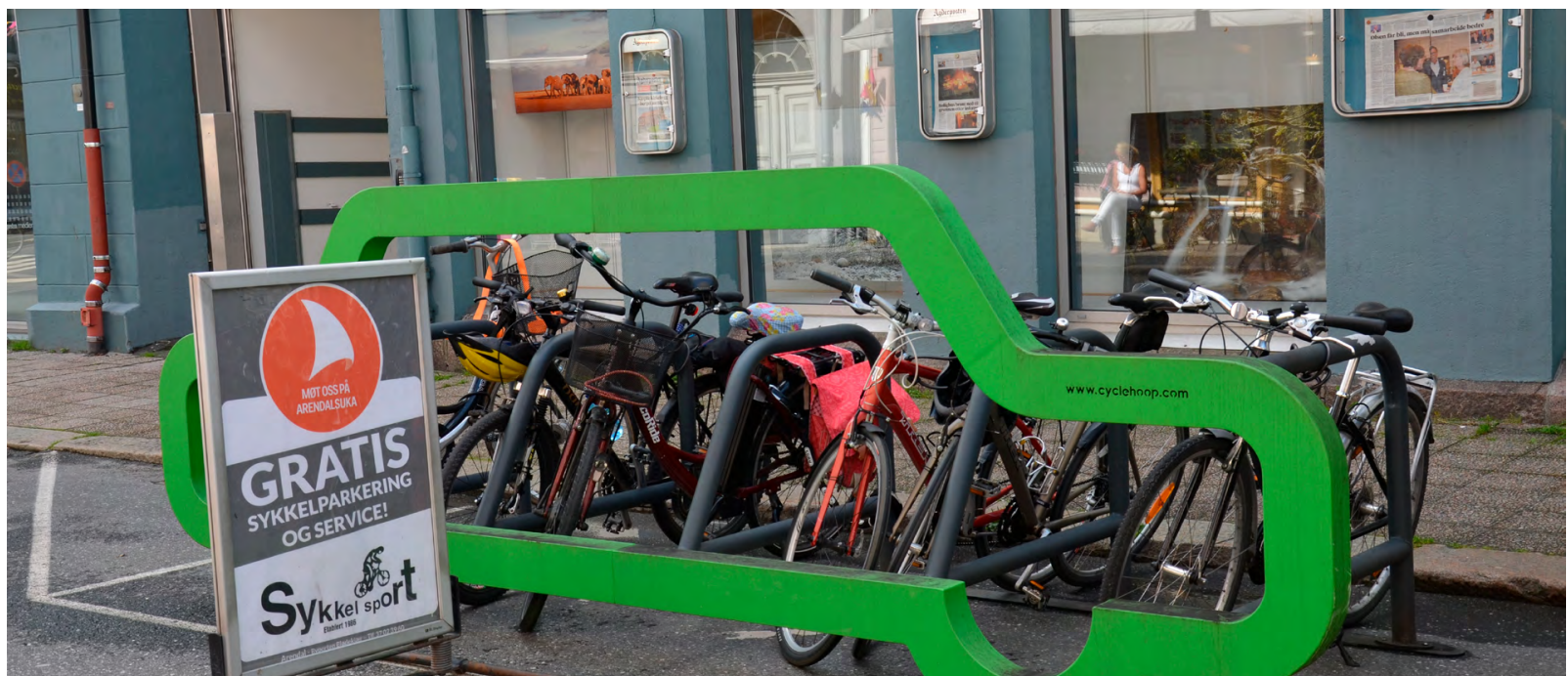

Källa: Arendals kommun

Invånarantal: 44,645 (2018)

- Medeltät kommun

Utgångspunkt: I Arendal ligger GRID-centret (Global Resources Information Database) som ingår i FN:s miljöprogram UNEP. Centret invigdes 1989 av dåvarande statsministern Gro Harlem Brundtland som en norsk uppföljning på Brundtlandrapporten. På ett UNEP-möte vid GRID-Arendal 2007 beskrev Torill Rolstad Larsen, som då var kommunens ordförande, ambitionen att göra kommunens drift klimatneutral enligt FN:s definition. Förslaget godkändes enhälligt av kommunfullmäktige 2008 och sedan dess har kommunen arbetat för att minska sina utsläpp. Arendal arbetar nu med Agenda 2030 i samband med sin klimat- och utsläppspolitik.

Mål och prioriteringar: Arendal fokuserar stort på hållbarhetsmål 13: vidta omedelbara åtgärder för att bekämpa klimatförändringarna och dess konsekvenser. Miljöstrategin "Grön strategi för Arendal" utarbetas som bäst och är avsedd att utgöra underlag för en ny klimat- och energiplan. Arendals vision är att vara "en nationellt ledande och internationellt erkänd klimat- och miljöstad samt en förebild för andra kommuner". Strategin fastställer vidare att kommunen ska stimulera etablerade och nya företag att utvecklas i en grönare riktning.

Genomförande och resultat: Arendals interna tekniska drift är redan klimatneutral enligt FN:s definition och uppvisar en reduktion från 2007 till
2017 på 80 \% av de totala utsläppen. En ny klimatoch energiplan ska antas i slutet av 2018 och förslaget i den är att Arendal ska sikta på liknande resultat i alla lokala förvaltningar. Kommunens ambitioner ska alltid följa Parisavtalets mål om att begränsa den globala uppvärmningen till långt under $2^{\circ} \mathrm{C}$ och ligga i linje med de mest ambitiösa städerna i Europa med under 100000 invånare. Arendal har också antagit ett ramverk för offentlig upphandling som ålägger leverantörerna att rapportera utsläppen från sin verksamhet. Målet är att öka genomsynligheten för utsläpp inte bara inom den offentliga sektorn, utan även från privata tjänsteleverantörer. Arendal står årligen värd för konferensen Fremtidens kommuner/Arendalkonferensen. Den för samman lokala myndigheter och andra intressenter inom den offentliga och privata sektorn och underlättar utbyte av innovativa idéer inom smart och grön utveckling.

Nästa steg: Arendal uppdaterar för närvarande sin kommunplan så att den får en robust grund $i$ Agenda 2030. Det råder politisk konsensus i den riktningen, även om det ännu inte finns ett skriftligt fastställt mandat. Utskottet som förbereder den nya kommunplanen diskuterar som bäst hur kommunens nämnder ska arbeta med de olika hållbarhetsmålen.

Vad kan andra kommuner lära sig av Arendal? Hur det går att aktivt delta i globala nätverk för förändringar och underlätta kunskapsutbyte med andra kommuner, exempelvis på en konferens. 


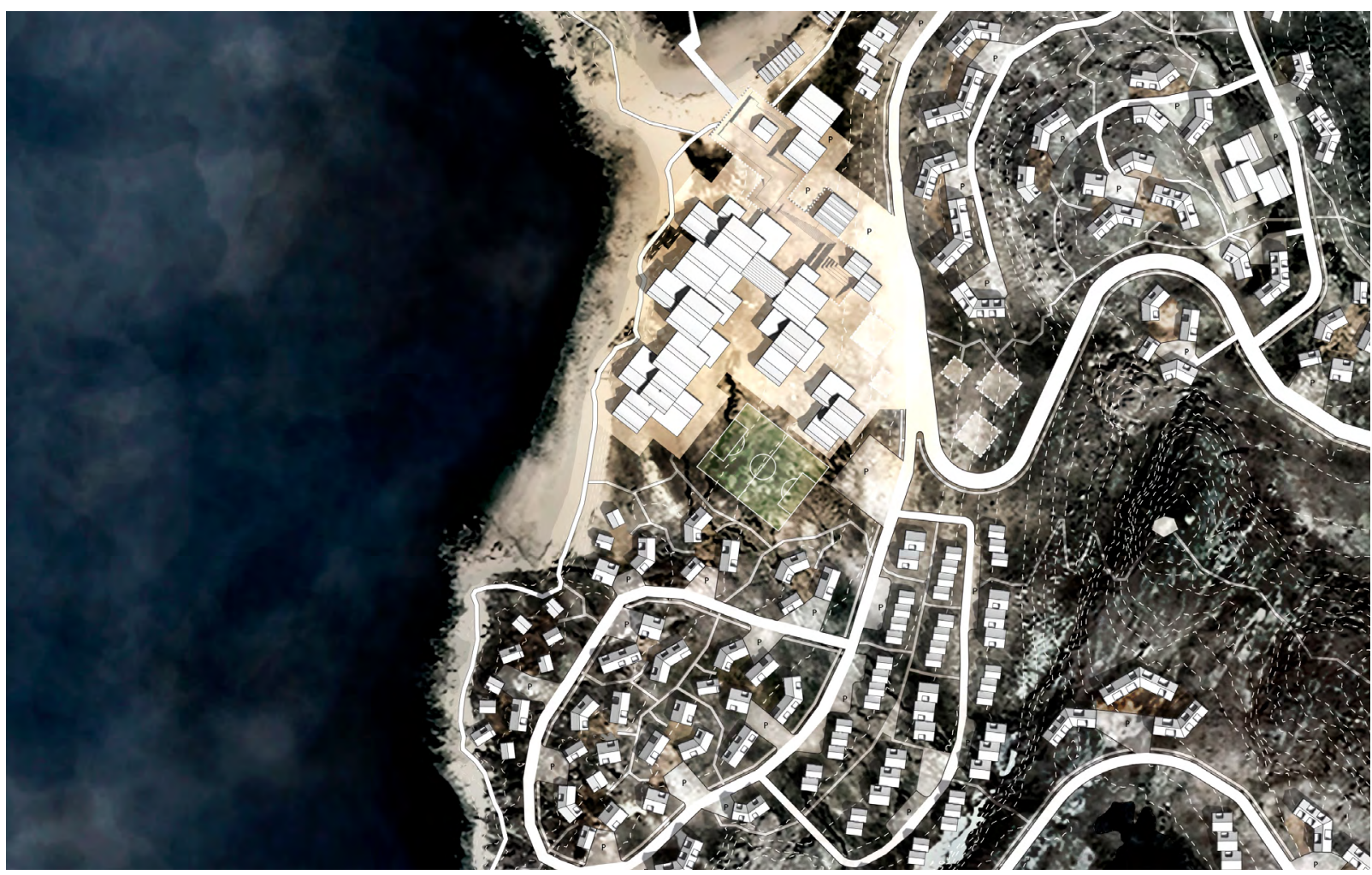

Källa: Siorarsiorfik - Nuuk City Development

Invånarantal: 22,738 (2018)

Utgångspunkt: Hösten 2017 deltog tre medarbetare från avdelningen för stads- och bostadsutveckling i en kurs om Agenda 2030. Det blev startskottet för kommunens arbete med hållbarhetsmålen. Kommunen beslöt definiera hållbarhetsmål för utvecklingen av Siorarsiorfik med hjälp av de globala målen. Siorarsiorfik är en ny förort till huvudstaden Nuuk, som Sermersooqs kommun planerar. Det övergripande målet är att främja Nuuk som en nyckelstad i hela den arktiska regionen för att stödja ekonomisk tillväxt och livskvalitet för alla nya invånare i Siorarsiorfik och säkerställa att alla byggnaderna i det nya området är funktionella, hållbara och tilltalande.

Mål och prioriteringar: Designmanualen för Siorarsiorfik beskriver planeringsvisionen och de strategiska målen för utvecklingen av Siorarsiorfik i åtta kapitel (Kommuneqarfik Sermersooq 2017). Manualen omfattar teman som landskapsplanering och infrastruktur, byggnader och offentliga rum, konst och kollektivtrafik. Den hänvisar explicit till sex av hållbarhetsmålen. De används för att definiera hur hållbarhetshänsyn ska styra utvecklingen av Siorarsiorfik. I målen som manu- alen fastställer ingår att all energi i förorten ska komma från hållbara källor, byggnaderna ska byggas med hållbara material och teknologier, kollektivtrafiken ska vara tillgänglig för alla och öppna platser ska så långt det är möjligt bevaras i sitt naturliga tillstånd för att skydda områdets biologiska mångfald.

Genomförande och resultat: Sermersooq har inrättat en stiftelse för tillsynen av Siorarsiorfiks utveckling. Fokus ligger på att säkerställa att målen och prioriteringarna i designmanualen uppfylls i alla skeden av projektets genomförande, från planering och design till byggandet.

Nåsta steg: En av de första byggnaderna som byggs inom ramen för Siorarsiorfik-projektet är en skola. Kommunen lägger för närvarande sista handen vid planeringen och byggarbetet inleds inom kort. Den första delen av en ny kuststig kommer också att etableras inom den närmaste framtiden. Därutöver ska Sermersooq börja använda Agenda 2030 och de 17 hållbarhetsmålen som ett strategiskt instrument för planering av aktiviteter inom andra förvaltningsområden.

Vad kan andra kommuner lära sig av Sermersooq? Hur hållbarhetsmålen kan användas för stadsplanering och stadsutveckling. 


\section{Tórshavn (FO)}
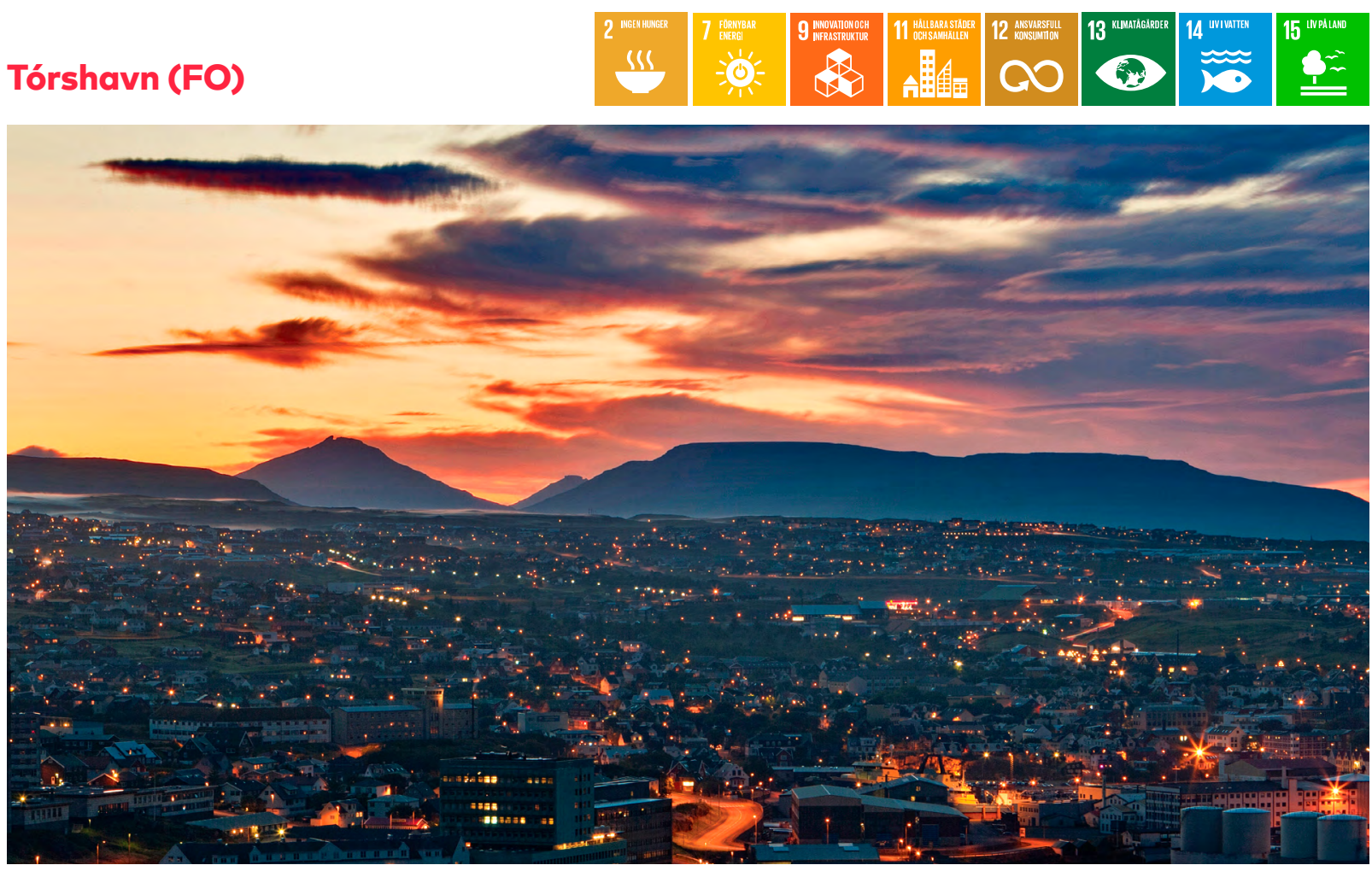

Källa: Tórshavns kommun

Invånarantal: 21,127 (2018)

Utgångspunkt: Medarbetare på planerings- och miljöavdelningen hörde först talas om Agenda 2030 på ett dialogmöte om nordiskt samarbete för hållbar utveckling i Helsingfors 2016. För att lära sig mer om arbete med hållbarhetsmålen i praktiken besökte en delegation Köpenhamns kommunala avdelning för hållbar utveckling för att utbyta idéer, särskilt om hur unga kan fås att engagera sig.

Mål och prioriteringar: Tórshavn antog en ny miljöpolicy 2016 (Tórshavnar kommuna 2016). Arbetet med den hade dock inletts redan 2014 och därför nämns hållbarhetsmålen inte explicit i dokumentet. Trots det motsvarar de miljömässiga hållbarhetsmålen målen och prioriteringarna som definieras för Tórshavn i policydokumentet:

- Grön energi: vatten- och vindkraft främjas, byggnaders isolering förbättras, invånare uppmuntras att gå, cykla och använda elbilar, gratis kollektivtrafik

- Avfallshantering: återvinning, kompostering och cirkulär ekonomi främjas, plastanvändning minskas

- Naturen: miljön skyddas mot föroreningar, grönområden i staden och byar förbättras och utvecklas
Kommunala åtgärder: miljöaspekter beaktas vid upphandling, energianvändning och övrig verksamhet.

Genomförande och resultat: Många av åtgärderna som beskrivs i miljöpolicyn har redan genomförts och flera projekt har startat. Exempelvis är stadens bussar gratis. Elbilar och cyklar finns tillgängliga för alla kommunalt anställda. Ett leksaksbibliotek är ett av de nyaste initiativen för cirkulär ekonomi. Kommunen arrangerar också årligen en miljövecka med olika tema varje år. 2018 låg fokus på livsmedelssäkerhet och hållbar livsmedelsproduktion. Bland annat inbjöds skolelever att delta i workshoppar om hållbarhet. Kommunen anordnar också föreläsningar och exkursioner för invånare i alla åldrar.

Nästa steg: Miljöpolicyn revideras och uppdateras med några års mellanrum. Sambandet mellan hållbarhetsmålen och de olika lokala prioriteringarna görs explicit när policyn revideras nästa gång. Även om Tórshavn inte ännu uttryckligen arbetar med hållbarhetsmålen, är det den första kommunen på Färöarna som går i denna riktning och är alltså föregångare i sin region.

Vad kan andra kommuner lära sig av Tórshavn? Hur det går att arrangera en hållbarhetsvecka med aktiviteter för hela befolkningen. 


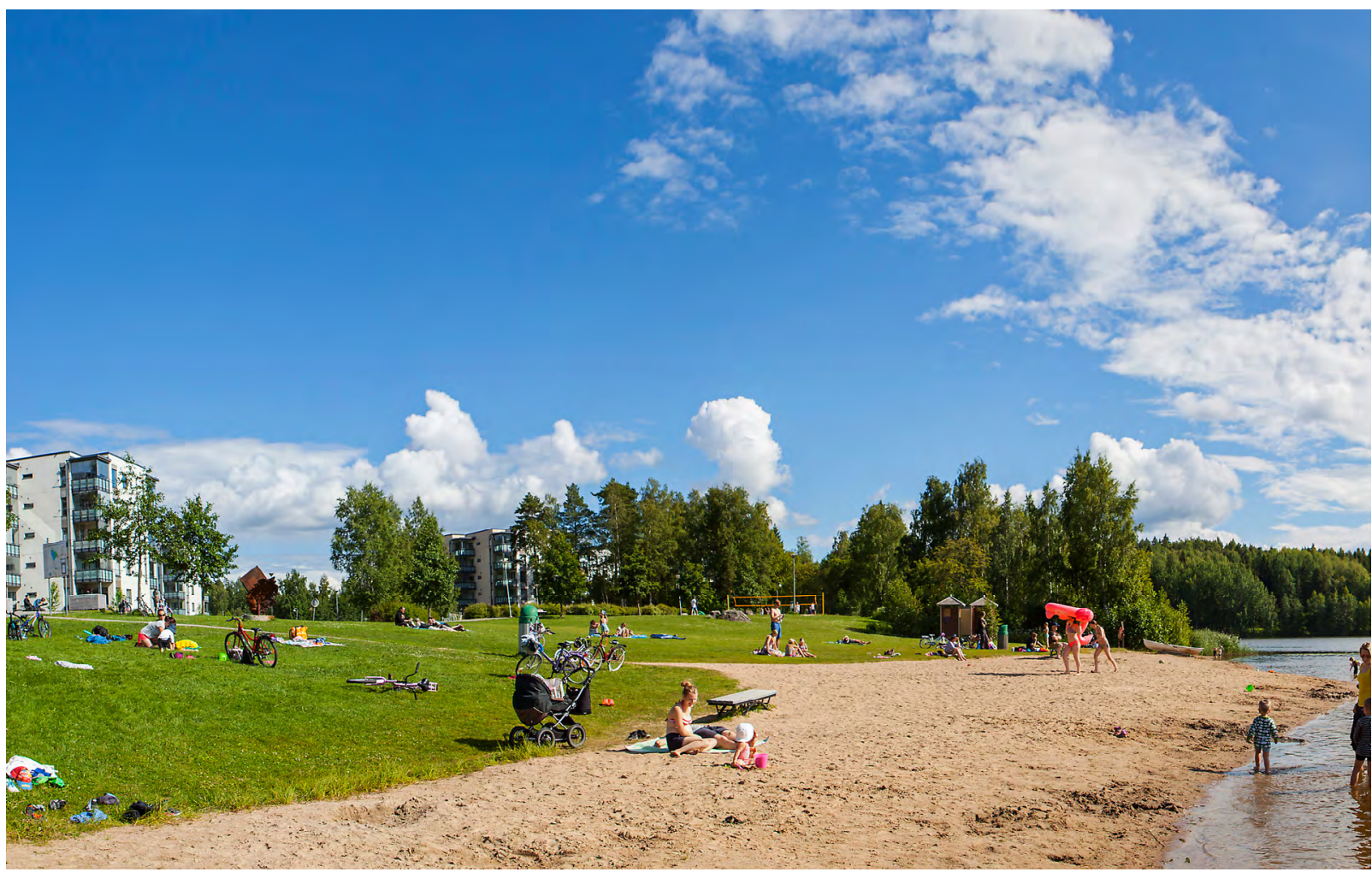

Källa: Birkala kommun

[ Invånarantal: 19,237 (2018)

- Medeltät kommun. Kärna i den funktionella stadsregionen Tammerfors

Utgångspunkt: Birkala antog nya miljömål 2016 som har kopplats till Agenda 2030. Kommunen implementerar sina miljömål genom det finska initiativet Commitment2050. På initiativets webbplats har Birkala publicerat ett åtagande som beskriver kommunens miljömål och hur de anknyter till hållbarhetsmålen.

Mål och prioriteringar: Birkalas mål fokuserar på stadsplanering, energi, natur och utbildning. Kommunen strävar efter att: 1) göra stadsstrukturen enhetligare genom att bygga ut kommuncentrum och förbättra kollektivtrafiken, 2) främja energieffektiva lösningar och användning av förnybar energi i kommunens nya byggprojekt, 3) främja ekosystemtjänster och biologisk mångfald samt förutse och förbereda sig på konsekvenserna av klimatförändringarna, och 4) ta fram miljöläromedel och samarbeta med företag för att hitta lösningar på miljöföroreningar.
Genomförande och resultat: Ett utskott för hållbar utveckling inrättades 2017 med det centrala uppdraget att främja hållbarhet i Birkala. Utskottet förbereder och planerar åtgärder och projekt och presenterar dem för berörda beslutsfattare. Därtill har kommunens samtliga förvaltningar definierat sina egna åtaganden för hur de kan bidra till förbättrad hållbarhet i Birkala. På en specifik webbplats kan invånare, privata företag och andra intressenter delta $\mathrm{i}$ kommunens arbete med hållbar utveckling.

Nåsta steg: Flera ambitiösa projekt planeras för närvarande. Bland annat är avsikten att gå med i Hinku-forum, ett nätverk av kommuner som har förbundit sig till att avsevärt minska sina växthusgasutsläpp. Kommunen diskuterar också hur den kan förbättra återvinningen av avfall och energieffektiviteten. En planerad åtgärd är att installera bullerskydd längs motorvägen som kan producera solenergi. Birkala kommun förbereder också en hållbar transport- och trafikplan med stöd från finska Trafikverket.

Vad kan andra kommuner lära sig av Birkala? Hur hållbarhetsplaneringen kan främjas och centraliseras med hjälp av ett utskott. 


\section{Mariehamn (AX)}
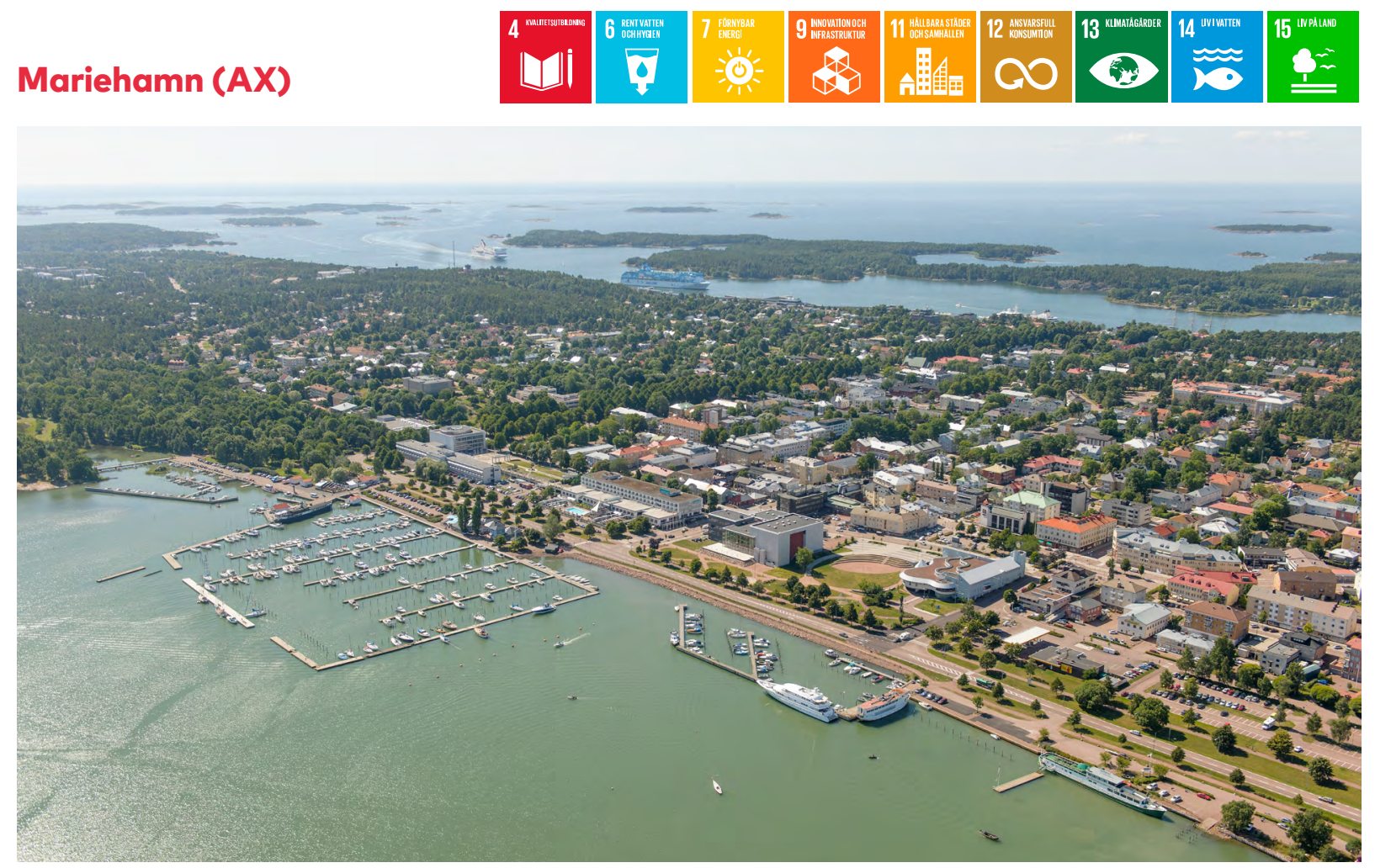

Källa: Mariehamns kommun

[ Invånarantal: 11,677 (2018)

- Medeltät kommun

Utgångspunkt: Mariehamn antog sina första lokala miljömål 2005. När ett nytt miljöprogram för perioden 2018-2030 diskuterades och antogs 2017, beslöt kommunen att koppla sina mål till Agenda 2030 och hållbarhetsmålen. Mariehamn prioriterar miljömässig och social hållbarhet i förvaltningen av stadens verksamheter.

Mål och prioriteringar: I sitt nya miljöprogram har Mariehamn som mål att minska stadens miljöpåverkan och att skapa en allt bättre livsmiljö för invånarna. Programmet definierar mål inom följande områden som alla anknyter till ett eller flera av hållbarhetsmålen:

- Energi: Mariehamn strävar efter att minska koldioxidutsläppen med $85 \%$ fram till 2030.

- Trafik: Koldioxidutsläppen från trafiken ska minska med $50 \%$ fram till 2030.

- Hållbar konsumtion: Mariehamn ska öka andelen inköp av ekologiska livsmedel och miljöanpassade varor och tjänster.

- Natur och vatten: Grönområden ska bevaras och miljöpåverkan på kuster, stränder, floder och andra vattendrag ska minskas. Kommunens förvaltningar och invånare ska få bättre information om Mariehamns natur och miljö.
Anpassning till klimatförändring: Kommunen gör upp scenarier för Åland och Mariehamn och identifierar områden och sektorer som är särskilt känsliga för klimatförändringar. Rapporten definierar även åtgärder som ska vidtas för att uppnå respektive mål.

Genomförande och resultat: I november 2017 tillsatte kommunfullmäktige ett utskott med uppdraget att utföra en politisk utvärdering och genomföra miljöprogrammet. Många åtgärder som bidrar till de fem målen pågår redan. Exempelvis ökar kommunen antalet elbilar för att minska sin klimatpåverkan och har introducerat en "klimatsmart dag" i veckan när det serveras enbart vegetarisk mat i Mariehamns skolor och daghem. Kommunen har även antagit nya riktlinjer för användning av miljövänliga städprodukter, möbler och leksaker i daghemmen.

Nästa steg: Andra åtgärder och projekt kommer att inledas inom de närmaste månaderna. Kommunen ska bland annat anlägga två våtmarker som bidrar till att rena Mariehamns vatten från föroreningar, däribland mikroplast, och erbjuder invånarna friluftsområden.

Vad kan andra kommuner lära sig av Mariehamn? Hur hållbarhetsmålen kan anknytas till ett miljöprogram med relevanta lokala mål. 


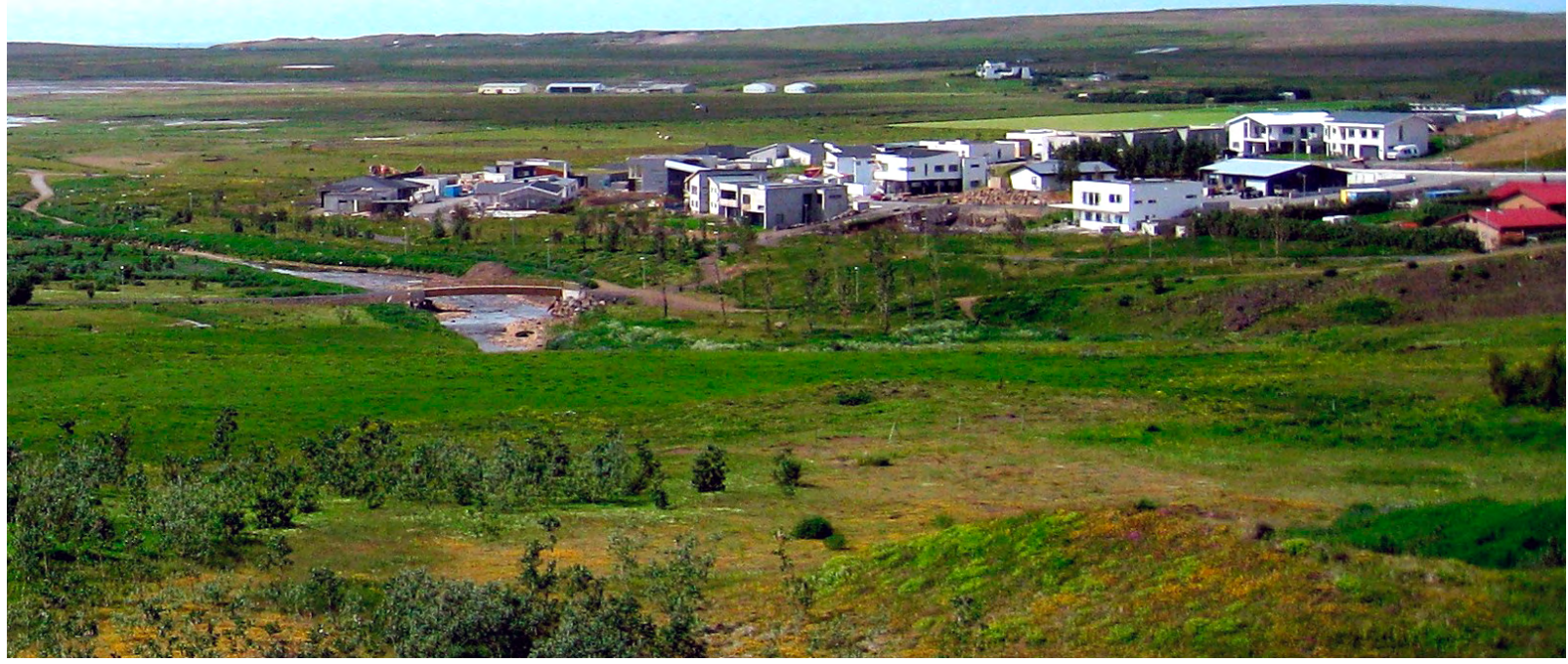

Källa: Mosfellsbærs kommun

- Invånarantal: 10,556 (2018)

nedeltät kommun

Utgångspunkt: Mosfellsbær planerar att implementera Agenda 2030 med hjälp av en ny miljöpolicy. Kommunen arbetade mycket aktivt med lokala Agenda 21 och därmed sågs Agenda 2030 och hållbarhetsmålen som ett naturligt ramverk för att fortsätta detta arbete.

Mål och prioriteringar: Kommunen har lagt stor vikt vid att involvera den lokala befolkningen i utvecklingen av den nya miljöpolicyn. I mars 2018 inbjöds invånarna till ett möte på en skola för att dela med sig av sina idéer och visioner för vad kommunen borde försöka uppnå under de närmaste åren och vilka miljöfrågor som borde prioriteras. Lokala politiker lyssnade och antecknade idéer. Bidragen från mötet jämfördes med Agenda 2030 för att identifiera likheter och ett förslag till en ny miljöpolicy har tagits fram med detta som underlag.
Genomförande och resultat: Förslaget till miljöpolicy fastställer ett antal mål, bland annat att utveckla Mosfellsbær på ett hållbart och progressivt sätt, skydda naturen och främja invånarnas livskvalitet. Dessa mål ska uppnås med hjälp av åtgärder inom 10 sektorer, exempelvis miljöutbildning, hållbar transport, och avfallshantering. Policyn beskriver målen i varje sektor och planerade åtgärder för att uppnå dem och anknyter explicit respektive sektor till ett eller flera av hållbarhetsmålen.

Nåsta steg: Det hölls lokalval på Island den 26 maj 2018 och det beslöts att miljöpolicyn ska antas och genomföras av det nya kommunfullmäktige. Det ger de nyvalda fullmäktigeledamöterna möjlighet att få med sina egna idéer och prioriteringar. Därmed säkerställs också att den nya policyn har allas stöd.

Vad kan andra kommuner lära sig av Mosfellsbær? Hur invånarna kan engageras i arbetet med hållbarhetsmålen genom offentliga möten. 
Tabell 1: 27 idéer för att genomföra Agenda 2030 i en lokal kontext

Kom igång, säkerställ framsteg och gör uppföljning

1. Starta i mindre skala och genomför Agenda 2030 genom att fokusera på några hållbarhetsmål i taget $(\rightarrow$ som Kemi)

2. Inrätta ett hållbarhetsutskott för att samordna arbetet ( $\rightarrow$ som Birkala)

3. Använd rumslig analys för att besluta vilka hållbarhetsmål ska prioriteras i olika stadsdelar $(\rightarrow$ som Uppsala)

4. Använd index och indikatorsystem för att mäta framstegen ( $\rightarrow$ som Kópavogur)

Integrera hållbarhetsmålen i centrala styrdokument, planer och processer

5. Använd Agenda 2030 för att ta fram en kommunstrategi ( $\rightarrow$ som Gladsaxe)

6. Anknyt ett miljöprogram till hållbarhetsmålen ( $\rightarrow$ som Mariehamn)

7. Ta fram en livskvalitetplan för den lokala befolkningen med kopplingar till hållbarhetsmålen $(\rightarrow$ som

Helsingborg)

8. Integrera hållbarhetsmålen i processerna för budgetering och beslutsfattande ( $\rightarrow$ som Malmö)

Involvera alla avdelningar inom kommunen

9. Utmana alla förvaltningar att förbinda sig till åtgärder för hållbarhet ( $\rightarrow$ som Tammerfors)

10. Ta fram ett hållbarhetsprogram med bidrag från alla förvaltningar ( $\rightarrow$ som Åtvidaberg)

\section{Engagera invånarna}

11. Ta fram hållbara lösningar tillsammans med befolkningen genom levande laboratorier ( $\rightarrow$ som Köpenhamn)

12. Arrangera en hållbarhetsvecka ( $\rightarrow$ som Tórshavn)

13. Lyssna till invånarnas idéer på öppna möten ( $\rightarrow$ som Mosfellsbær)

14. Engagera invånarna med hjälp av positiva scenarier ( $\rightarrow$ som Kristiansund)

\section{Uppmuntra unga att delta}

15. Ingå starka partnerskap med skolor för att engagera unga ( $\rightarrow$ som Sønderborg)

16. Utveckla appar och spel för att lära unga om hållbarhet ( $\rightarrow$ som Esbo)

17. Arrangera diskussioner om hållbarhet mellan politiker och skolelever ( $\rightarrow$ som Umeå)

18. Ge ut en bok om hållbarhet och hållbarhetsmålen ( $\rightarrow$ som Gotland)

\section{Stöd hållbara företag och organisationer}

19. Dela ut hållbarhetspris ( $\rightarrow$ som Odense)

20. Koppla näringsstrategin till hållbarhetsmålen och stöd hållbara företag ( $\rightarrow$ som Bergen)

21. Designa en grön stadskarta ( $\rightarrow$ som Århus)

Använd hållbarhetsmålen i stadsplanering och hållbart bostadsbyggande

22. Använd hållbarhetsmålen för att utveckla en ny förort ( $\rightarrow$ som Sermersooq)

23. Främja grönt boende och ekobyar ( $\rightarrow$ som Hurdal)

Ingå starka partnerskap

24. Arrangera en konferens för att utbyta erfarenheter med andra kommuner ( $\rightarrow$ som Arendal)

25. Arrangera seminarium med företag och ideella organisationer för att planera arbetet ( $\rightarrow$ som Växjö)

26. Engagera intressenter från den privata sektorn och civilsamhället inom olika sektorer ( $\rightarrow$ som Örebro)

Eller till och med ...

27. Använd hållbarhetsmålen som vägledning vid en kommunsammanslagning ( $\rightarrow$ som Asker, med Hurum och Røyken) 


\section{Analys: Framgångsfaktorer, utmaningar och nästa steg i genomförandet av Agenda 2030 på lokal nivå}

De 27 kommunerna som ingick i den här studien varierar i storlek och befolkningsmängd. De har olika miljömässiga och geografiska förutsättningar samt skillnader i sina organisationsstrukturer och politiska ledning. Dessa olikheter påverkar kommunernas möjligheter att erbjuda offentlig service, utmaningarna de står inför och deras möjligheter att anta utmaningarna i fråga om budget, kunskap och personal. Kort sagt är lokala förhållanden avgörande för hur Agenda 2030 genomförs i kommunen. Analysen nedan syftar till att se bortom dessa olikheter för att hitta gemensamma nordiska drag.

\section{Framgångsfaktorer och lärdomar på lokal nivå}

De två faktorer för framgångsrikt arbete med Agenda 2030 som nämndes av de flesta intervjuade är politiskt stöd från kommunfullmäktige och engagemang från kommunens alla förvaltningar gällande hållbarhetsarbetets utveckling och genomförande. Kommunerna rekommenderade också att relatera Agenda 2030 och hållbarhetsmålen till arbetet som redan utförs på lokal nivå. Några tjänstepersoner sade att det har varit nyttigt att skapa en berättelse om kommunens framtid och använda denna berättelse i kontak-

\section{$C$ Kemi är en liten kommun, vilket är en fördel.}

Alla känner varandra så det är lätt att inleda samarbete och administrativa ärenden sköts enklare. Små kommuner kan stå inför utmaningar i arbetet med hållbarhetsmålen på grund av sin storlek, men de har också dessa fördelar. TJÄNSTEPERSON I KEMI KOMMUN, FINLAND terna med kollegor, invånare, företag och ideella organisationer. En användbar metod för att skapa en sådan berättelse är att anordna strategiska workshoppar för politiker och tjänstepersoner för att analysera hållbarhetsmålen och hur de relaterar till den specifika lokala kontexten. Respondenter från mindre kommuner framhöll att deras storlek kan vara en fördel eftersom det är enkelt att hålla kontakt internt och arbeta över hierarkioch sektorsgränser.

\section{Utmaningar i genomförandet av Agenda 2030}

En av de vanligaste utmaningarna i arbetet med Agenda 2030 som lyftes fram i diskussionerna var integreringen av hållbarhetsmålen i kommunens styrning. Några lokala tjänstepersoner sade att det saknas intresse eller att de möts av en skeptisk inställning hos kollegor, chefer och politiker. De framhöll att det är nödvändigt att konstant påminna om varför det är viktigt att arbeta med

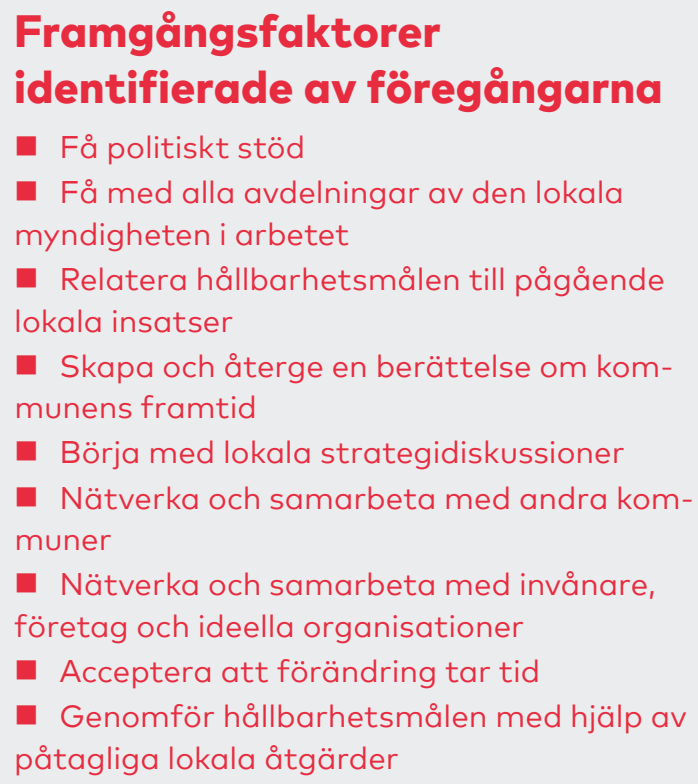


hållbarhetsteman som fred, jämställdhet och miljöskydd i den nordiska kontexten. Detta sammanhänger med utmaningen att göra det globala relevant lokalt och att hjälpa folk att inse att Agenda 2030 är viktig för alla, inte något som ska genomföras av någon annan och någon annanstans. Involvering av aktörer utanför de lokala myndigheterna betraktas också som en utmaning. Några av de intervjuade kämpar för att hitta de bästa sätten att engagera invånare, lokala företag och ideella organisationer.

\section{C6} början var det svårt att få folk att förstå Agenda 2030 och hållbarhetsmålen, vad de handlar om och hur de hänger ihop med Odense. Ett av de första hållbarhetsmålen är "ingen hunger". När vi började tala om hållbarhetsmålen, var publiken ofta lite förundrad över hur hållbarhetsmålen är relevanta för Odense, på grund av det här målet. Det kanske föreföll som en sak mer relevant för utvecklingsländer. TJÄNSTEPERSON I ODENSE KOMMUN, DANMARK

Det är dock inte alla intervjuade tjänstepersoner från föregångskommunerna som har mött utmaningar i sitt arbete med Agenda 2030 och hållbarhetsmålen. Några av dem konstaterade att det inte förekom utmaningar, men att arbetet med hållbarhetsmålen är en pågående lärandeprocess där det inte finns något som är absolut "rätt" eller "fel".

66

Det är ingen utmaning, vi är vana vid att arbeta med målintegrering i styrsystem. Vi är vana vid att arbeta med hållbarhetsärenden. Hållbarhetsmålen förs in i det nuvarande styrsystemet.

TJÄNSTEPERSON I UPPSALA KOMMUN, SVERIGE

\section{Utmaningar identifierade av föregångarna}

- Integrering av arbetet internt i kommunen: Åtgärda brist på engagemang och skepticism. De intervjuade rapporterar ett ständigt behov att sporra tjänstepersoner och förvaltningschefer att ta ansvar.

- Integrering av arbetet externt: Engagera övriga intressenter genom extern kommunikation och nätverkande. Få med lokala företag i arbetet.

- Göra det globala relevant på lokal nivå: Få människor att inse att Agenda 2030 är för alla och inte bara något som genomförs av någon annan och någon annanstans.

- Mål och prioriteringar: Prioritera mål och åtgärder och samtidigt bevara konsensus om att Agenda 2030 har en holistisk betydelse. Lösa potentiella konflikter mellan vissa av hållbarhetsmålen.

- Tid: Acceptera att det tar tid att genomföra förändringar i en organisation. Budgetar och investeringar planeras på kort sikt, men resultaten från hållbarhetsinsatser syns först på lång sikt.

- Jämförelse av framsteg med andra kommuner: Många indikatorer kan jämföras enbart på lands- och/eller regionnivå. Indikatorer som mäter lokala framsteg är sällan standardiserade mellan kommunerna.

- Begränsningar i budget och resurser: Lösa brist på personal som ägnar sig åt hållbarhet inom kommunen.

- Brist på stöd från regeringen och/eller regionala myndigheter: Utmaningarna sammanhänger med finansiering, prioritering, nätverksmöjligheter, jämförelser och samordning.

- Hållbarhetsmålen erbjuder alltför många möjligheter: Beslut om hur och var arbetet med hållbarhetsmålen ska börja. Definition av relevanta åtgärder.

- Kontraproduktiv lagstiftning: Vissa nationella och europeiska lagar och policyer är kontraproduktiva mot Agenda 2030 i och med att de befrämjar fossila bränslen och kontinuerlig ekonomisk tillväxt. 


\section{Nästa steg för att genomföra Agenda 2030 på lokal nivå}

I intervjuerna ombads tjänstepersonerna från föregångskommunerna komma med förslag på hur politiker på regional, nationell eller nordisk nivå kan stödja deras arbete med Agenda 2030 och hållbarhetsmålen, och hur kommunerna själva kan vidta ytterligare åtgärder för att säkerställa framgång i arbetet. De intervjuade sade att hjälp från nationella regeringar och Nordiska ministerrådet verkligen skulle kunna stödja deras lokala arbete. Exempelvis kunde nationella regeringar kommunicera tydligare vilka hållbarhetsmål och anknytande aktiviteter de prioriterar och hur nationella instanser och delegationer arbetar för att genomföra Agenda 2030. På så sätt kan kommunerna undvika sådant arbete som står i konflikt med nationella insatser och prioriteringar.

Några intervjuade påpekade också att nationella aktörer måste förstå att processen med att identifiera hållbarhetsprioriteringar, utveckla och genomföra åtgärder och mäta deras effekter sammanhänger med lokala förhållanden. De flesta intervjuade kommuner vill mäta sina framsteg $\mathrm{i}$ jämförelse med andra kommuner och regioner. Det finns flera globala mätinstrument och jämförelseindikatorer för detta ändamål, men om kommunerna inte använder samma indikatorer är det omöjligt att göra direkta jämförelser. Vissa intervjuade konstaterade dock att jämförelse med andra kommuner inte är något som de prioriterar. De arbetar för politikerna och kommuninvånarna och ser inte sådana jämförelser som sitt ansvar.

\section{$1<$ Det är viktigt att Nordiska ministerrådet och de na-} tionella myndigheterna beviljar finansiering, kommunicerar hur Agenda 2030 är relevant i vår nordiska kontext, och utvärderar vad kommunerna gör för att genomföra Agenda 2030 och hur vi gör det.

TJÄNSTEPERSON I UMEÅ KOMMUN, SVERIGE

\section{Rekommenderade nösta steg}

Nationella regeringar och/eller Nordiska ministerrådet kan:

- erbjuda specifik utbildning om arbetet med hållbar utveckling på lokal nivå

- öka finansieringen för strategiska insatser och spridningsaktiviteter om hållbarhetsmålen på lokal nivå, exempelvis för inledande aktiviteter som workshoppar och utbildning samt för att mäta effekterna

- koppla finansieringen till prestationer $\mathrm{i}$ arbetet med hållbarhetsmålen (till exempel länka anslag för infrastrukturinvesteringar till höga poäng i social hållbarhet); detta kan öka arbetet inom flera sektorer och/eller dimensioner av hållbarhet

- kommunicera mer med lokala myndigheter om deras prioriteringar gällande Agenda

2030

- erbjuda mer information och utbildningskampanjer om Agenda 2030 och hållbarhetsmålen på alla nordiska språk för att öka kunskapen bland allmänheten

- skapa fler tillfällen för kunskapsdelning mellan kommuner

- bidra till att öka medvetenheten om att valet av prioriteringar, deras genomförande och mätningen av deras effekter är avhängiga av lokala förhållanden - bevilja ett hållbarhetpris för att belöna hållbara företag, skolor, institutioner och andra offentliga eller privata aktörer

Regionala myndigheter kan:

- mäta framsteg med enhetliga indikatorer för att möjliggöra jämförelse mellan kommuner, utan att bortse från analysen av vad respektive indikator innebär på lokal nivå - sprida goda exempel och lösningar som inspiration, men även återge misslyckade fall så att lokala myndigheter kan ta lärdom av andras misstag och problemlösningsförmåga Lokala myndigheter kan:

- förbättra relationerna mellan lokala politiker och tjänstepersoner, så att fullmäktige begär evaluering av resultaten från hållbarhetsåtgärder för att sporra förvaltningen

- använda europeiska direktiv för upphandling, miljökonsekvensbeskrivning (för projekt) och strategisk miljöbedömning (för planer och program) mer konsekvent för att uppfylla Agenda 2030

- involvera barn i processen med att genomföra Agenda 2030 


\section{Slutsatser och framtidsutsikter}

Denna rapport har identifierat 27 nordiska kommuner som föregångare i att genomföra Agenda 2030 och de 17 hållbarhetsmålen. Andra kommuner planerar för närvarande att koppla lokala prioriteringar till de globala målen och kommer förmodligen att ingå i gruppen av föregångare inom de närmaste åren. Erfarenheterna som beskrivs $i$ denna rapport är avsedda att ge idéer och vägledning för den processen.

Profiltexterna i rapporten visar att det finns många angreppssätt för att inleda arbetet med Agenda 2030 i en lokal kontext. Några kommuner använder hållbarhetsmålen som ett kommunikationsinstrument. Genom att koppla befintliga eller nya åtgärder till hållbarhetsmålen visar kommunerna hur de bidrar till de globala målen med att fokusera på lokala prioriteringar. Andra kommuner vänder sig till hållbarhetsmålen för inspiration. Några intervjuade tjänstepersoner konstaterade att hållbarhetsmålen kan utgöra ett starkt incitament för att "höja ribban" och sätta upp ambitiösare mål för den lokala kontexten. Hållbarhetsmålen kan också användas som en checklista. Några kommuner jämför systematiskt pågående verksamheter med de 17 hållbarhetsmålen för att identifiera styrkeområden och områden där kommunen kan prestera bättre. Enskilt eller i kombination kan dessa angreppssätt utgöra en givande utgångspunkt för andra kommuner som vill påbörja arbete med Agenda 2030.

En jämförelse av de 27 profiltexterna visar att föregångarna genomför lokala strategier, planer och program för Agenda 2030 på olika sätt. Vissa kommuner prioriterar utvalda hållbarhetsmål. Andra strävar efter att bygga upp en allmän kultur där Agenda 2030 beaktas i alla rutiner och processer som helhet. Några kommuner betonar starkt engagemanget av unga i sitt arbete med hållbarhetsmålen, medan andra involverar företag eller ideella organisationer. Kommunerna skiljer sig också åt när det gäller vilka förvaltningar eller enheter som styr arbetet och hur andra sektorer och avdelningar involveras. Vissa av dessa angreppssätt och prioriteringar beror på kommunens särdrag. Föregångarna som porträtteras här fördelar sig på alla nordiska länder och regioner och inkluderar små städer och huvudstäder, öar, kust- och inlandskommuner, kommuner med enorma landområden, som Sermersooq, och kommuner med mindre områden, som Kemi. Oavsett vilket angreppssätt en kommun väljer, tas ett viktigt steg när politisk konsensus uppnås, mandat avtalas och hållbarhetsmålen skrivs in i styrdokument.

Med tanke på fortsatta åtgärder gav de intervjuade tjänstepersonerna ett antal rekommendationer för hur nationella och nordiska myndigheter kan stödja implementeringen av Agenda 2030. Tydlig kommunikation av nationella prioriteringar och aktiviteter inom Agenda 2030, vägledning för arbete med de 17 hållbarhetsmålen och hjälp med att mäta framstegen är de centrala förslagen. Stöd inom dessa områden skulle inte bara hjälpa föregångarna att gå vidare med sitt arbete, utan kan också uppmuntra fler kommuner att bidra till de globala målen.

Ett klart flertal av de kommunrepresentanter som intervjuades för detta projekt bekräftade också att ett nordiskt nätverk där lokala myndigheter regelbundet kan utbyta erfarenheter vore nyttigt för deras arbete. Budskapet är tydligt, men formatet och det praktiska arrangemanget för ett sådant samarbete behöver preciseras. Ett förslag är att använda de befintliga nätverk som finns i och med de nordiska ländernas kommunförbund. Det vill säga SKL i Sverige, KL i Danmark, KS i Norge, Kommunförbundet i Finland, och Samband på Island. 


\section{Referenslista}

Aarhus Kommune 2016: Climate Plan 2016-2020. http://reader.livedition.dk/ aarhuskommune/749/html5/.

Bergen Kommune 2015: Bergen 2030.

Kommuneplanens Samfunnsdel. https:// www.bergen.kommune.no/hvaskjer/tema/ bergen-2030.

Bergen Kommune 2016: Green Strategy. Climate and Energy Action Plan for Bergen. https://www.bergen.kommune.no/english/ publications/article-142407.

Bergen Kommune 2017: Handlingsplan for Næringsutvikling i Bergen 2017-2018. https:// www.bergen.kommune. no/omkommunen/ avdelinger/byradsavd-for-klima-kultur-ognaring/6570/6574/ article-150124.

Danmarks regering 2017: Report for the Voluntary National Review. Denmark's implementation of the 2030 Agenda for Sustainable Development, Ministry of Finance: Copenhagen.

Deloitte 2018: From global goals to local action, Deloitte: Copenhagen.

Finlands kommission för hållbar utveckling 2016. En målbild för Finland 2050 - Samhälleligt åtagande för hållbar utveckling. Webbplats: https://commitment2050.fi/.

Gladsaxe Kommune 2018: Gladsaxestrategien.

Bæredygtig vækst og velfærd 2018-2022. http:// www.gladsaxe.dk/ gladsaxestrategien.

Haraldsson, Gunnar, Friðriksson, Kári S och Jónsdóttir, Rósbjörg 2018: Social Progress Portrait Kópavogur 2018. https:// www. socialprogress.is.

Helsingborgs kommun 2016: Helsingborgs Livskvalitetsprogram Styrdokument för folkhälsa och miljö. https:// livskvalitet. helsingborg.se/styrdokument-och-program/ vad-ar-livskvalitetsprogrammet/.

Hurdal Kommune 2018: Hurdal kommuneplan 2018 - 2040. https://www. hurdal. kommune.no/aktuelt/kunngjoring--- hurdalkommuneplan-2018---2040/.

Islands regering 2018: Heimsmarkmið. Sameinuðu pjóðanna um sjálfbæra próun. Stöðuskýrsla. https://www.stjornarradid.is.

Kommuneqarfik Sermersooq 2017: Siorarsiorfik. Byen i landskabet, Landskabet i byen.

Designmanual 1. Udgave. http:// sermersooq2028.gl/dk/redegoerelse/ temaplaner/siorarsiorfik-designmanual-/ siorarsiorfik-designmanual-.htm

Kristiansund Kommune 2017: Handlingsprogram Kristiansund kommune. Budsjett 2018, Økonomiplan 2018-2021. https://www. kristiansund.kommune.no/ tjenester/politikkog-administrasjon/ styringsdokument/ handlingsprogram/.

Københavns Kommune 2018: The Capital of Sustainable Development. The City of Copenhagen's Action Plan for the Sustainable Development Goals. https:// international. kk.dk/artikel/copenhagen- welcomes-un-sdgs.

Nordiska ministerrådet 2017: Generation 2030. Ytterligare information: http://www. norden. org/en/theme/generation-2030.

Norges regering 2016: Voluntary National Review 2016. Initial steps towards the implementation of the 2030 Agenda. https://sustainabledevelopment. un.org/ memberstates/norway.

OECD 2013: Definition of Functional Urban Areas (FUA) for the OECD metropolitan database. http://www.oecd.org/ cfe/regionalpolicy/Definition-of-Functional- Urban-Areasfor-the-OECD-metropolitan-database.pdf

Regeringskansliet 2018: Handlingsplan Agenda 2030 2018-2020. https://www.regeringen. se/rapporter/2018/06/handlingsplanagenda-2030/

Sachs, J., Schmidt-Traub, G., Kroll, C., Lafortune, G., Fuller, G. 2018: SDG Index and Dashboards Report 2018, Bertelsmann Stiftung and Sustainable Development Solutions Network (SDSN): New York.

Tórshavnar kommuna 2016: Grøna Leiðin.

Umhvørvispolitikkur fyri Tórshavnar kommun. https://www.torshavn.fo/ Default. aspx?pageid $=1674$.

Uppsala kommun 2017: Mål och Budget 20182020. https://www.uppsala.se/ organisationoch-styrning/publikationer/mal- ochbudget-2018-2020/.

Zoeteman, K., Paenen, S.,Mulder, R., Wentink,

C. 2017: Benchmarking Sustainability performance of Espoo with selected EU cities. A 2017 benchmark study of 15 selected high scoring cities in Northern Europe, Telos

Brabant Centre for Sustainable Development: Tilburg.

Zoeteman, K., Mulder, R., Smeets, R., Wentink,

C. 2016: Towards Sustainable EU Cities. A quantitative benchmark study of 114 European and 31 Dutch cities, Telos Brabant Centre for Sustainable Development: Tilburg.

Åtvidabergs kommun 2016: Hållbarhetsprogram för Åtvidabergs Kommun. https://www. atvidaberg.se/kommun-och- politik/hallbarutveckling. 


\section{Valet av kommuner}

Organisationerna som bidrog till att hitta föregångarkommuner inkluderar kommunorganisationer som danska KL (Kommunernes Landsforening) och Sveriges Kommuner och Landsting (SKL) samt stads- och kommunnätverk som Nordic City Network, Rådet för kommuner och regioner i Europa (CEMR) och Eurocities. Medlemmar i de tre temagrupperna inom Nordiska ministerrådets ämbetsmannakommitté för regionalpolitik (ÄKR), för vilka Nordregio är sekretariat, rekommenderade också kommuner för detta projekt, Nordiska ministerrådets expertgrupp för hållbar utveckling gav även värdefulla råd.

I vissa länder, framför allt Sverige och Danmark, rekommenderades så många kommuner att alla inte kunde intervjuas. I dessa två länder valde författarna kommuner genom att ställa dem $i$ rangordning enligt hur många gånger de rekommenderades och intervjuade dem som kom högst på listan. Motivet till det här förfarandet var att de bäst kända och oftast rekommenderade kommunerna sannolikt var de som kommit längst i sitt arbete med hållbarhetsmålen och kunde därmed definieras som föregångare i sitt land.

\section{Intervjuer med kommunala tjönstepersoner}

Författarna genomförde halvstrukturerade intervjuer med alla utvalda kommuner. De intervjuade var tjänstepersoner inom den offentliga förvaltningen, strateger inom social, miljömässig och/eller ekonomisk hållbarhet, samt stads- och allmänna planerare. Diskussionerna med de intervjuade följde löst ett förberett frågeformulär som omfattade bland annat följande ämnen: motivationen att arbeta med Agenda 2030, målen som kommunen försöker uppnå, åtgärderna och projekten de genomför, angreppssätten de använder för att involvera invånarna (i synnerhet unga), utmaningar som de möter $i$ arbetet med Agenda 2030 och hur de tacklar dessa utmaningar.

\section{Urbaniseringsgrad}

Eurostat använder sig av tre kategorier för att beskriva urbaniseringsgrad ${ }^{3}$ :

- Tätbefolkad kommun (densly populated area) - minst 50 \% av befolkningen bor i tätbefolkade kluster

- Medeltät kommun (intermediate density area) - mindre än $50 \%$ av befolkningen bor på landsbygden och mindre än $50 \%$ bor i tätbefolkade kluster

- Glest befolkad kommun (thinly populated area) - över $50 \%$ av befolkningen bor på landsbygden.

\section{Funktionell stadsregion}

En funktionell stadsregion (functional urban area, FUA) består av en stad (urban kärna) och dess pendlingszon (omland). En urban kärna består av ett tätbefolkat kluster av sammanhängande områden med en befolkningstäthet på minst 1 500 invånare per kvadratkilometer. En kommun definieras som del av en urban kärna om minst $50 \%$ av befolkningen bor i ett urbant kluster. Om minst $15 \%$ av de arbetande invånarna i en kommun arbetar $i$ en grannkommun definierad som en urban kärna, kallas denna kommun ett omland. I denna rapport definieras dessa kommuner som "del" av en funktionell stadsregion (OECD 2013).

\section{Analys och jåmförelse}

Resultaten presenterade i diskussionskapitlet baserar sig på anteckningarna från samtliga intervjuer med lokala myndigheter. För analysen kodades anteckningarna i det kvalitativa analysverktyget NVivo och dominerande teman framkom genom kodningsprocessen. För klarhets skull ska det noteras att alla intervjuade inte listade framgångsfaktorer, utmaningar, nästa steg eller policyrekommendationer.

\footnotetext{
${ }^{3}$ http://ec.europa.eu/eurostat/web/degree-of-urbanisation/ background
} 


\section{Presentation av projektets resultat}

Resultaten från detta projekt presenterades på ett seminarium den 9 maj 2018 hos Nordregio i Stockholm. Politiker och tjänstepersoner från nordiska kommuner, medarbetare från kommunorganisationer, regionala organisationer, konsultbyråer och regeringskanslier deltog i seminariet. Utöver presentation av projektets centrala resultat, presenterade utvalda föregångskommuner sitt arbete med Agenda 2030. Seminariedeltagarna gav återkoppling i interaktiva diskussioner och reflekterade över framgångsfaktorer, utmaningar och rekommendationer för arbetet med Agenda $2030 .{ }^{4}$

${ }^{4}$ Presentationer och sammandrag av diskussioner finns på adressen: http://www.nordregio.org/events/agenda-2030at-the-local-level/. 



\section{(1I) Nordregio}

P.O. Box 1658

SE-111 86 Stockholm, Sverige

nordregio@nordregio.org

www.nordregio.org

www.norden.org

ISBN 978-91-87295-70-6

ISSN 1403-2503

DOI: doi.org/10.30689/R2019:5.1403-2503 